\title{
The Lower Cretaceous
}

(Albian) Ammonite Genera

Leconteites and Brewericeras

GEOLOGICAL SURVEY PROFESSIONAL PAPER 503-F

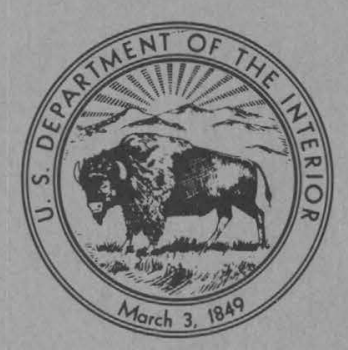





\title{
The Lower Cretaceous
}

(Albian) Ammonite Genera

Leconteites and Brewericeras

\author{
By DAVID L. JONES, MICHAEL A. MURPHY, and EARL L. PACKARD
}

CONTRIBUTIONS TO PALEONTOLOGY

GEOLOGICAL SURVEY PROFESSIONAL PAPER 503-F

$A$ report simplifying the complex

nomenclature of the ammonite

genera Leconteites and Brewericeras

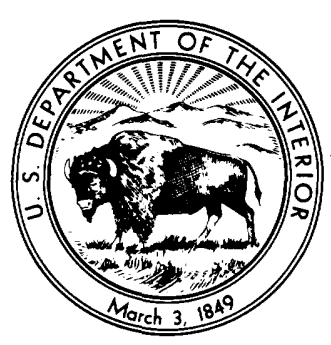

UNITED STATES GOVERNMENT PRINTING OFFICE, WASHINGTON : 1965 


\section{UNITED STATES DEPARTMENT OF THE INTERIOR}

STEWART L. UDALL, Secretary

GEOLOGIGAL SURVEY

Thomas B. Nolan, Director

For sale by the Superintendent of Documents, U.S. Government Printing Office Washington, D.C. 20402 - Price .50 (paper cover) 


\section{CONTENTS}

Abstract

Introduction

Nomenclature

Acknowledgments, measurements, and abbreviations

Material studied

Stratigraphic position and age of Leconteites and Breweri-

ceras.

Ono area $\ldots \ldots \ldots \ldots$

\begin{tabular}{|c|c|}
\hline ge & \\
\hline F1 & Stratigraphic position and age-Continued \\
\hline 1 & Central Oregon \\
\hline 1 & Queen Charlotte Islands. \\
\hline 3 & Southern Alaska \\
\hline 3 & Evolutionary sequence. $\ldots$ \\
\hline & Systematic descriptions \\
\hline 3 & References \\
\hline & lex $\ldots \ldots$ \\
\hline
\end{tabular}

Page

F5

6

7

8

9

19

21

\section{ILLUSTRATIONS}

[Plates 1-11 follow index]

Plate 1, 3-5. Leconteites lecontei (Anderson).

2. Leconteites lecontei (Anderson) and L. sacramenticus (Anderson).

6. Leconteites lecontei whiteavesi Jones, Murphy, and Packard, n. subsp. and L. deansi (Whiteaves).

7. Leconteites lecontei whiteavesi Jones, Murphy, and Packard, n. subsp.

8. Breuericeras breweri (Gabb) and B. hulenense (Anderson).

9, 10. Brewericeras hulenense (Anderson).

11. Brewericeras hulenense and Leconteites lecontei.

FiguRe 1. Index map of Ono area, northern California

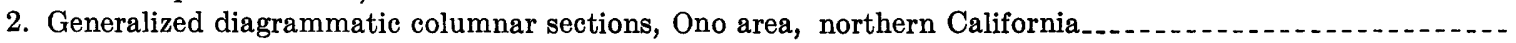
3-5. Index map of-

3. Mitchell area, central Oregon..........

4. Graham Island, Queen Charlotte Islands, B.C

5. The upper Chitina Valley, southern Alaska.

6. Generalized columnar section, Fohlin Creek area

7. Postulated evolutionary sequence of Leconteites and Brewericeras

8. Cross sections of Leconteites lecontei $\mathrm{s} . \mathrm{s}$

9. Scatter diagram showing relation of whorl height to whorl breadth in Leconteites lecontei s. s........

10. Bar graph showing frequency distribution of Leconteites lecontei $\mathrm{s} . \mathrm{s}$

11-13. Suture lines of Leconteites lecontei $\mathrm{s} . \mathrm{s}$

14. Scatter diagram, Brewericeras hulenense

15, 16. Suture lines of Brewericeras hulenense

17. Bar graph showing frequency distribution of Brewericeras hulenense

Page 


\title{
CONTRIBUTIONS TO PALEONTOLOGY
}

\section{THE LOWER GRETACEOUS (ALBIAN) AMMONITE GENERA LECONTEITES AND BREWERICERAS}

\author{
By David L. Jones, Michael A. Murphy, ${ }^{1}$ and Earl L. Packard ${ }^{2}$
}

\begin{abstract}
Lower Cretaceous (Albian) ammonites from the Pacific coast region of North America designated as Leconteites lecontei, $L$. modestum (in part), Puzosigella mulleri, $P$. taffi, $P$. rogersi, and $P$. perrinsmithi (in part), are herein regarded as forming one highly variable but intergrading species to which the name $L$. lecontei (Anderson) is applied. Puzosigella sacramentica (Anderson) is regarded as a separate species of Leconteites, and the name $P$ Puzosigella is rejected. A new subspecies, $L$. lecontei whiteavesi, is recognized from the Albian beds of Queen Charlotte Islands, and one species, $L$. deansi, is abundant in the lowest Albian beds of southern Alaska.

The genus Brewericeras is regarded as a direct descendant of Leconteites and contains two species: $B$. breweri (Gabb) and $B$. hulenense (Anderson). $B$. brewer $i$ is known only from one specimen, but $B$. hulenense is abundant and widespread in upper lower Albian deposits. This species shows a wide range in morphologic variation from smooth compressed forms to ribbed slightly inflated forms.
\end{abstract}

\section{INTRODUCTION}

Ammonites assigned to various species of the genera Leconteites Casey, Puzosigella Casey, and Brewericeras Casey are locally abundant in Albian strata in California, Oregon, British Columbia, and Alaska. Because of their wide distribution and short geologic range, these ammonites are very useful in correlation, but because of the proliferation in specific names, uncertainty of generic affinities, and obvious synonymy of some of the types, their proper identification is impossible using the present nomenclature.

Likewise, an apparent evolutionary sequence of the early Albian Leconteites leading to the late early Albian or early middle Albian Brewericeras has been obscured by placing these two genera in different families: Leconteites in Hoplitidae and Brewericeras in Desmoceratidae (Wright in Arkell and others, 1957).

In recent years, studies of large populations of ammonites have shown that some species exhibit a

\footnotetext{
1 University of California, Riverside, Calif.

2 Stanford University, Stanford, Calif.
}

surprisingly wide range of morphologic variation. Studies of the Upper Cretaceous Collignoniceratids by Haas (1946), the Triassic genus Tropites by Silberling (1959), and the mid-Cretaceous genus Neogastroplites by Reeside and Cobban (1960) conclusively demonstrate that intraspecific variation from finely ribbed compressed individuals to robust coarsely ornamented forms is normal for some ammonites and that finely drawn taxonomic distinctions based on differences in whorl proportions or strength of ornamentation do not hold up when a sufficiently large sample is available. On the other hand, some groups of ammonites are remarkably constant morphologically and show little range in variation. Why this difference exists is not clear, but it seems probable that the highly variable species are most important from an evolutionary point of view, as they provide a wider basis upon which natural selection can operate to produce separately evolving strains.

This study attempts to document another example of extreme variation and also to elucidate what seems to be a clear evolutionary sequence.

\section{NOMENCLATURE}

The genera Leconteites and Puzosigella are based on two species, Desmoceras lecontei and Pachydiscus sacramenticus, first named by Anderson (1902). According to Anderson, the former species is characterized by a compressed whorl section, narrow umbilicus, nearly vertical umbilical wall, angular umbilical shoulder, and weak ornamentation; the latter species is characterized by a more inflated whorl section, wider umbilicus, sloping umbilical wall, rounded umbilical shoulder, and coarse ornamentation. Holotypes of both species apparently were obtained from the same place on the east fork of Huling (Hulen) Creek near Ono, northern California (California Acad. Sci. loc. 152 , see Anderson, 1902 , p. 96,$105 ; 1938$, p. 195, 196). 
Hall and Ambrose (1916, p. 69; see Wiedey, 1929, p. 25, pl. 2, fig. 2) subsequently named a new species, Sonneratia rogersi, a closely related form obtained from Tesla quadrangle in central California. Anderson (1938, p. 192, 193) later referred Desmoceras lecontei to Cleoniceras and named a new species, $C$. modestum, which was also obtained from Huling Creek (California Acad. Sci. loc. 1668). In the same publication, Anderson (1938, p. 184, 195) referred Pachydiscus sacramenticus to the genus Sonneratia and named as new species $S$. perrinsmithi, $S$. taffi, and $S$. mulleri all of which, together with plesiotypes of $S$. rogersi, were obtained from the east fork of Huling Creek (California Acad. Sci. loc. 152).

Casey (1954) recognized that none of the species cited above belong to either Cleoniceras or Sonneratia, and he therefore erected two new genera, Leccnteites and Puzosigella, and D. lecontei and P. sacramenticus, respectively, were designated as generic types.

To the genus Puzosigella, Casey assigned the following species: $P$. sacramenticus, S. mulleri, S. taffi, and $S$. rogersi. The distinctive features of Puzosigella were described by Casey (1954, p. 110), as follows:

*** evolute, subdiscoidal, strongly costate. Whorl-sides flattened, subparallel. Venter broadly rounded. Umbilicus with subvertical wall and distinct rim, surmounted, in the early whorls, by obtuse bullae, from which the sigmoidal ribs take origin in bundles. Ribs later tending to differentiate into (long) primaries and (short) secondaries, the latter either freeending or branching from the primaries at or below the middle of the sides. All ribs broadening slightly and fading on the venter, which they traverse in a forwardly directed arc, inner lateral area tending to smoothness at large diameters. Periodic narrow constrictions, not persistent to the adult. Suture line puzosoid.

Only one species, $D$. leconte $i$, was definitely assigned to Leconteites, but Casey (1954, p. 110) stated that "This genus, $* * *$ comprises the Californian 'Cleoniceras' of Anderson (1938)." Thus, at least by implication, $C$. modestum also was meant to be included in the genus. Leconteites was said to differ from Puzosigella.

in its greater involution, compression, finer ribbing, more delicate and less persistent umbilical tubercles, tendency to smoothness in the adult, and in the presence of periodic desmoceratidlike peripheral ridges. Constrictions, if ever present, disappear before the neanic stage (Casey, 1954, p. 110).

Imlay (1960) reported both Leconteites and Puzosigella in Albian deposits of the Chitina Valley, Alaska, where he recognized Puzosigella cf. P. rogersi, Leconteites modestus and $L$. deansi (Whiteaves). According to Imlay (1960, p. 108):

The genus Puzosigella differs from Leconteites mainly in having more prominent umbilical bullae, by the flank ribs originating in bundles at these bullae, and by possessing many, rather conspicuous, narrow constrictions on immature specimens.
A study of large collections of ammonities from Oregon, California, British Columbia, and Alaska have convinced the authors of this paper that the differentiation of leconteitid and puzosigellid ammonites into six species and two genera is untenable and that the generic differences expressed by Casey and by Imlay are invalid. Specimens from a single locality show a complete gradation from compressed finely ornamented forms (Leconteites) to the more inflated coarsely ribbed forms (Puzosigella). This same range of variation can be demonstrated to occur throughout the entire stratigraphic interval in which these forms occur. Thus only one generic name should be applied to this entire morphologic plexus.

The genus Brewericeras was named by Casey (1954, p. 112), who cited Ammonites breweri Gabb as type species. Ammonites breweri was originally based on a large fragment (UC 12098) figured by Gabb in 1864 and reproduced here on plate 8 , figures 3 and 5 . This specimen has strongly developed ribs that are continuous across the lower flanks and that show a slight tendency to weaken near the umbilical shoulder and on the venter. Because the specimen is worn and damaged in these areas, it is difficult to be sure that this weakening is inherent rather than due to erosion. In 1869 , Gabb illustrated another specimen (ANSP 4798) as $A$. breweri, and this was refigured by Anderson (1938, pl. 44 , figs. 1,2) and erroneously designated by him as the holotype. That specimen, reproduced in this report on plate 8 , figures 1,2 , and 4 , has ribs that are well developed on the outer flank but are weakly developed on both the inner flank and the venter, in marked contrast to the holotype.

In this same publication, Anderson (1938, p. 190, pl. 44, figs. 3, 4) named a new species, Beudanticeras hulenense, which differs from $A$. breweri by having ribs that are less prominent on the umbilical shoulder, absent on the lower flanks, and weak or absent on the venter. Typical specimens of $B$. hulenense are nearly smooth, but a completely intergrading series can be shown between smooth forms and more coarsely ribbed forms such as Gabb's 1869 specimen referred to as $A$. breweri. A complete intergradation cannot be demonstrated with the holotype of $A$. breweri (Gabb, 1864), as that specimen has coarser more uniformly developed ribs on the lower flank in contrast to all known specimens of $B$. hulenense, which lack the ribs or have only striae or, in the highly inflated varieties, irregularly developed riblets.

Therefore, these two species of Brewericeras are considered distinct, although $B$. breweri is known only from the single original (1864) specimen; all other cited examples of $B$. breweri are herein referred to $B$. hulenense. 
ACKNOWLEDGMENTS, MEASUREMENTS, AND ABBREVIATIONS

We are indebted to Dr. Leo Hertlein, of the California Academy of Sciences, for providing casts of Anderson's type specimens; to Dr. F. H. McLearn, of the Geological Survey of Canada, for making available specimens of Leconteites from the Queen Charlotte Islands; to Dr. A. Sutherland-Brown, of the British Columbia Department of Mines and Petroleum Resources, for furnishing maps and giving advice on fossiliferous localities in the Queen Charlotte Islands; to Dr. Horace Richards, of the Academy of Natural Sciences of Philadelphia; and to Mr. Joseph Peck, Department of Paleontology, University of California, Berkeley, for loaning us Gabb's original specimens. We also thank Dr. Marshall Maddox of San Jose State College for donating large collections of Leconteites made by himself and students in the Hospital Creek area, central California.

Measurements and abbreviations used in this report are as follows:

\begin{tabular}{|c|c|c|}
\hline Measurements & Abbreviations & Remarks \\
\hline Diameter of shell _... & $\mathrm{D}$ & $\begin{array}{l}\text { Maximum diameter not al- } \\
\text { ways measured, particu- } \\
\text { larly where outer part of } \\
\text { the whorl is damaged. }\end{array}$ \\
\hline Whorl height. ...... & $\mathrm{H}$ & $\begin{array}{l}\text { Measured along radial line } \\
\text { where diameter is meas- } \\
\text { ured. Taken on top of } \\
\text { ribs on all forms. }\end{array}$ \\
\hline Whorl breadth ..... & B & $\begin{array}{l}\text { Measured at same place as } \\
\text { H. Taken on top of ribs } \\
\text { but not including promi- } \\
\text { nent umbilical bullae. }\end{array}$ \\
\hline $\begin{array}{l}\text { Ratio of whorl breadth } \\
\text { to whorl height. }\end{array}$ & $\mathrm{B} / \mathrm{H}$ & \\
\hline Width of umbilicus_-- & $\mathrm{Um}$ & $\begin{array}{l}\text { Measured in millimeters and } \\
\text { also expressed as percent } \\
\text { of diameter. }\end{array}$ \\
\hline
\end{tabular}

Abbreviations.-CAS, California Academy of Sciences, San Francisco, Calif.; GSC, Geological Survey of Canada; LSJU, Leland Stanford, Jr. University, Stanford, Calif.; ANSP, Academy of Natural Sciences of Philadelphia; UC, University of California, at Berkeley; UCR, University of California, at Riverside; UO, University of Oregon, at Eugene; USGS, U.S. Geological Survey; USNM, U.S. National Museum, Washington, D.C.

\section{MATERIAL STUDIED}

Examples of Leconteites and Brewcriceras were studied from nearly all known occurrences in the Pacific coast region of North America. Figured specimens were selected from four localities: Huling Creek in northern California, where Gabb's and Anderson's types were obtained; near Mitchell, in central Oregon, where abundant specimens of Leconteites collected from throughout a very small stratigraphic interval reveal a nearly complete sequence of intergrading morphologic types; the Queen Charlotte Islands, B.C.; and southern Alaska. Specimens of Leconteites deansi (Whiteaves) from southern Alaska have recently been adequately figured by Imlay (1960), so only one specimen from that locality is illustrated in this report.

Approximate numbers from each general locality are tabulated as follows: (These include specimens in the collections of the U.S. Geol. Survey, Menlo Park; the California Academy of Sciences, San Francisco; and the University of California at Riverside and Los Angeles).

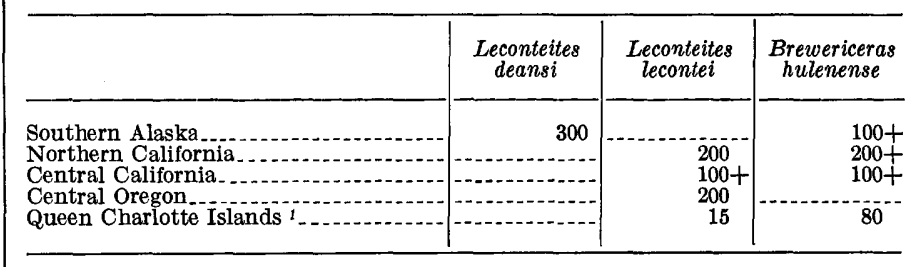

1 Specimens from Queen Charlotte Islands are regarded as a new subspecies of $L$. lecontei.

\section{STRATIGRAPHIC POSITION AND AGE OF LECONTEITES AND BREWERICERAS}

In the following summary, brief descriptions are given of the stratigraphic succession of beds containing Leconteites lecontei, $L$. deansi, and Brewericeras hulenense in the Ono area, northern California; near Mitchell in central Oregon; in Skidegate Inlet and Beresford Bay in the Queen Charlotte Islands; and in the upper Chitina Valley area in southern Alaska. Other areas are known where either or both genera occur, but the stratigraphic relations and faunal associations are best known and developed in the areas described.

\section{ONO AREA}

The beds in the vicinity of Ono have been studied by Gabb (1864, 1869), by Anderson (1938), and by Murphy (1956; in Murphy and Rodda, 1960; Murphy and others, 1964). This area contains one of the most continuous and richly fossiliferous sequences of Lower Cretaceous beds known on the west coast of North America. It has been the source of most of the stratigraphic nomenclature and serves as the local standard of reference for this region. Aptian and Albian beds are particularly fossiliferous, and a great number of described species were first collected there. These beds are well exposed along Huling Creek and along the East Fork of Huling Creek (fig. 1), where some of the specimens described in this report were obtained.

The Leconteites lecontei zone overlies the Acanthohoplites reesidei zone on and near Huling Creek and 


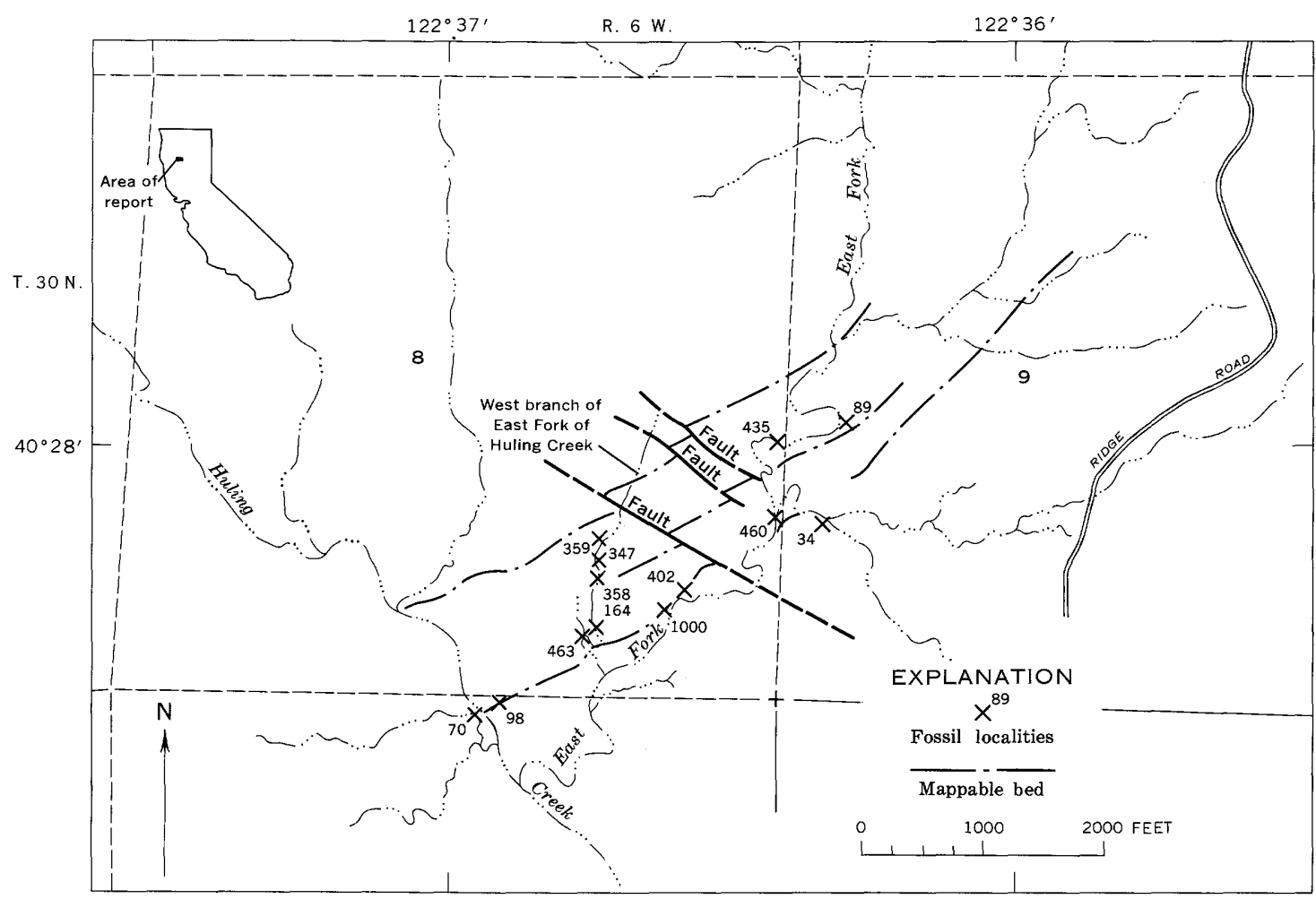

Figure 1.-Index map of the Ono area, northern California, showing generalized geology and University of California at Riverside localities from which specimens of Leconteites and Brewericeras were obtained.

ranges through about 270 feet of dominantly darkgray siltstone and mudstone which contains abundant limestone concretions (fig. 2). Throughout this thickness, but especially in the upper half, Leconteites lecontei s. s. is abundant and shows a wide range of morphologic variation. Three groups, each containing several specimens, were selected from the lower, the middle, and the upper part of the zone to show that throughout its known range, the species exhibits a similar degree of morphologic variation. From the lower part of the zone, illustrated specimens were obtained from UCR localities 347,359 , and 435; from the middle part, from UCR localities 89 and 358 ; and from the upper part, from UCR localities 164, 460 , and 463 .

Other ammonites associated with Leconteites lecontei in the Ono area are:

\section{Silesites puzosiaformis Anderson \\ Ptychoceras laeve (Gabb) \\ Hypophylloceras californicum (Anderson) \\ Tetragonites sp. \\ Douvilleiceras cf. D. mammillatum (Schlotheim) \\ Anagaudryceras gainesi (Anderson) \\ $A$. aurarium (Anderson) \\ $A$. cf. A. sacya (Forbes)}

As pointed out by Popenoe, Imlay, and Murphy (1960, p. 1509), this assemblage is undoubtedly of early or middle Albian age. An early Albian age is favored because it overlies beds containing Acanthohoplites, which ranges from late Aptian to early Albian, and is overlain by beds having abundant Douvilleiceras ef. $D$. mammillatum, of probable late early Albian age. The zone of Leconteites lecontei is correlative with at least part of the Leymeriella tardefurcata zone (see Wright, in Arkell and others, 1957, p. L128) of the European Albian, but a precise correlation is not possible.

The Leconteites lecontei zone on and near Huling Creek is overlain by slightly calcareous silty sandstone in which Brewericeras hulenense and other fossils are abundant. About 10 feet of barren beds intervene between the highest occurrence of $L$. leconte $i$ and the lowest occurrence of $B$. hulenense, but deposition was probably nearly continuous and only a relatively short time interval is represented by the barren beds.

The Brewericeras hulenense zone on and near Huling Creek is restricted to a single 10-foot-thick bed of sandy and pebbly mudstone. This bed may represent a submarine mudflow as it shows no internal bedding and the clasts have no preferred orientation. A few miles to the northeast near the old mining camp of Horsetown, a much greater thickness of strata, composed of poorly sorted sandstone, also represents the Brewericeras 


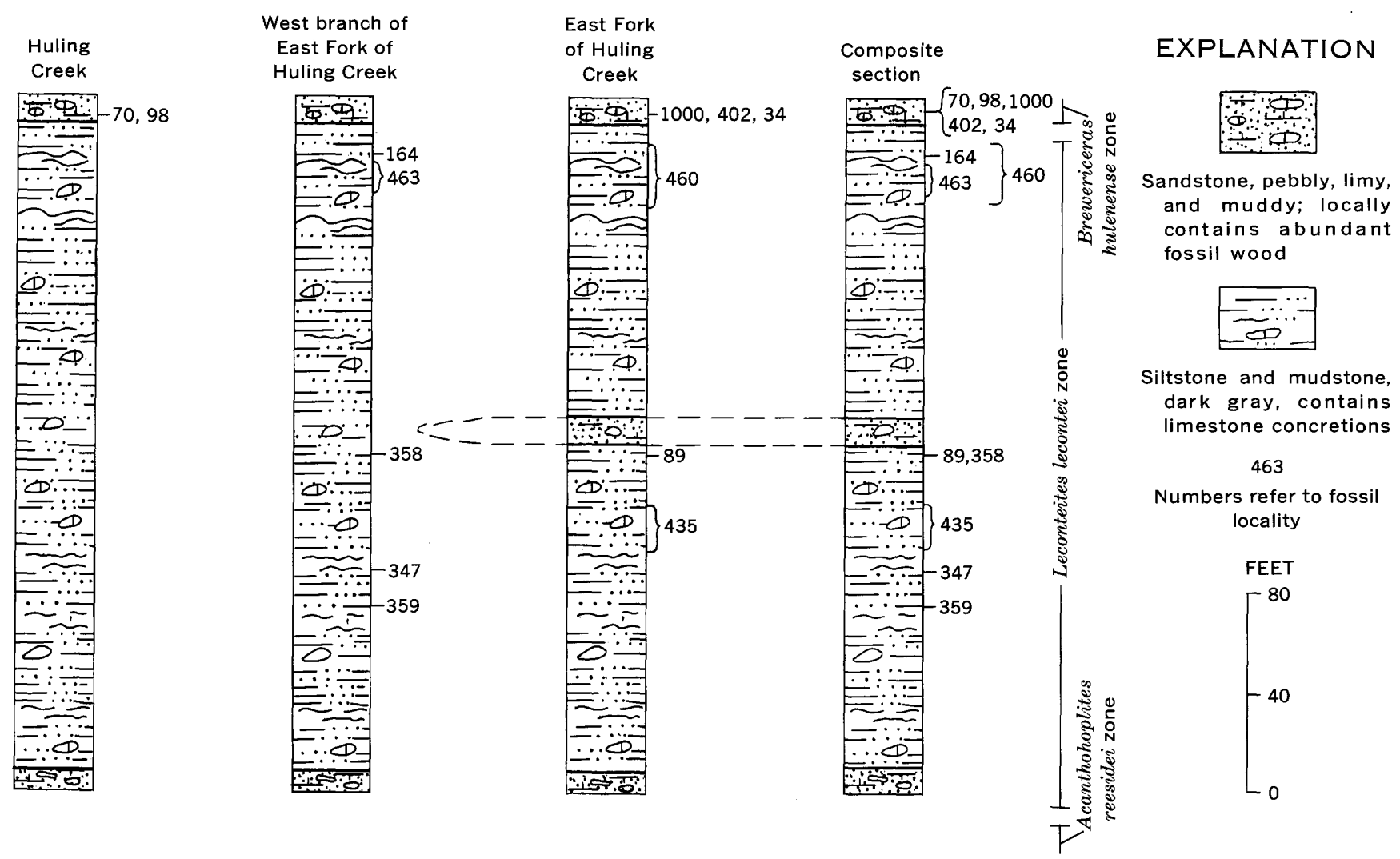

Figdre 2.-Generalized diagrammatic columnar sections showing stratigraphic position of fossil localities in the Ono area from which specimens of Leconteites and Brewericeras were obtained.

hulenense zone, and it is possible that the bed exposed at Huling Creek was derived from that area.

Other fossils associated with $B$. hulenense are:

Douvilleiceras cf. D. mammillatum (Schlotheim)

\section{D. restitutum? Anderson}

Puzosia subquadrata (Anderson)

Desmoceras merriami (Anderson)

Hypacanthoplites sp. = Parahoplites stantoni Anderson (holotype, not small specimen figured by Anderson, 1938, pl. 36, fig. 2)

Hypophylloceras californicum (Anderson)

Jauberticeras cf. J. michelianum (d'Orbigny)

Anagaudryceras gainesi (Anderson)

A. aurarium (Anderson)

Tetragonites sp.

In addition, the lowest beds of this zone on Huling Creek contain a few specimens intermediate in character between Brewericeras and Leconteites.

The Brewericeras hulenense zone is probably about equivalent to the Douvilleiceras mammillatum zone of European usage (see Wright, in Arkell and others, 1957, p. L128) and is assigned a late early Albian age.

Overlying the Brewericeras hulenense zone is 200 feet of barren siltstone, followed by a thin zone containing Oxytropidoceras packardi Anderson and associated fauna of probable middle Albian age.

\section{CENTRAL OREGON}

The sedimentary sequence of Albian age near Mitchell, central Oregon, consists of about 4,700 feet of mudstone, siltstone, and a minor amount of sandstone, which rests unconformably on Permian metasedimentary rocks (McKnight, 1964). The oldest fossil known is Leconteis leconteites. s. which occurs at many localities near the base of the sequence. These lower beds, in turn, are overlain by strata of the Brewericeras hulenense zone. As yet no detailed biostratigraphic studies have been carried out in the Mitchell area, and the thickness of strata included in these two zones is unknown.

The Leconteites beds have furnished more prolific and better preserved fossil collections than have the Brewericeras beds, and only specimens from the former are figured in this report. In order to avoid complexities due to time or facies differences, numerous specimens from the richest locality were first analyzed and the range of variation of what was considered to be a sample of a single ammonite population was established. Specimens from other localities were then compared to the control sample and differences or similarities noted. The specimens from the control sample were obtained 
from a bed of concretionary limestone nodules ranging from an inch to a foot or more in thickness interbedded with gray mudstone. This locality, consisting of separate collections numbered USGS Mesozoic locality 26262, 26378, M 2284, and UO 4082, is exposed north of the old Frizzell ranchhouse in sec. 3, T. 11 S., R. 22 E.; it is designated locality $\mathrm{A}$ in figure 3 . Most of the figured specimens from Oregon were obtained from this locality, but a few are from equivalent nearby strata. The exact locality of two figured specimens from USGS Mesozoic locality 15801 is uncertain.

Because of minor structural complexities, lack of key beds, and widely scattered fossil-collecting localities, it has not been possible to arrange all the specimens of Leconteites lecontei from Mitchell in precise stratigraphic order and demonstrate that the range of variation is constant, or nearly so, throughout the vertical range of the species. It could be argued that the wide range of morphologic variation shown by the specimens from locality $\mathrm{A}$ was the result of mixing together, in a condensed deposit, fossils of widely differing ages. This argument can be readily countered, for the species show virtually the same wide range in variation at every locality known, and specimens from the stratigraphically controlled sequence of Huling Creek, Calif., are figured to further document this variation.

\section{QUEEN CHARLOTTE ISLANDS}

Albian beds are best and most continuously exposed along the north shore of Skidegate Inlet (fig. 4) and

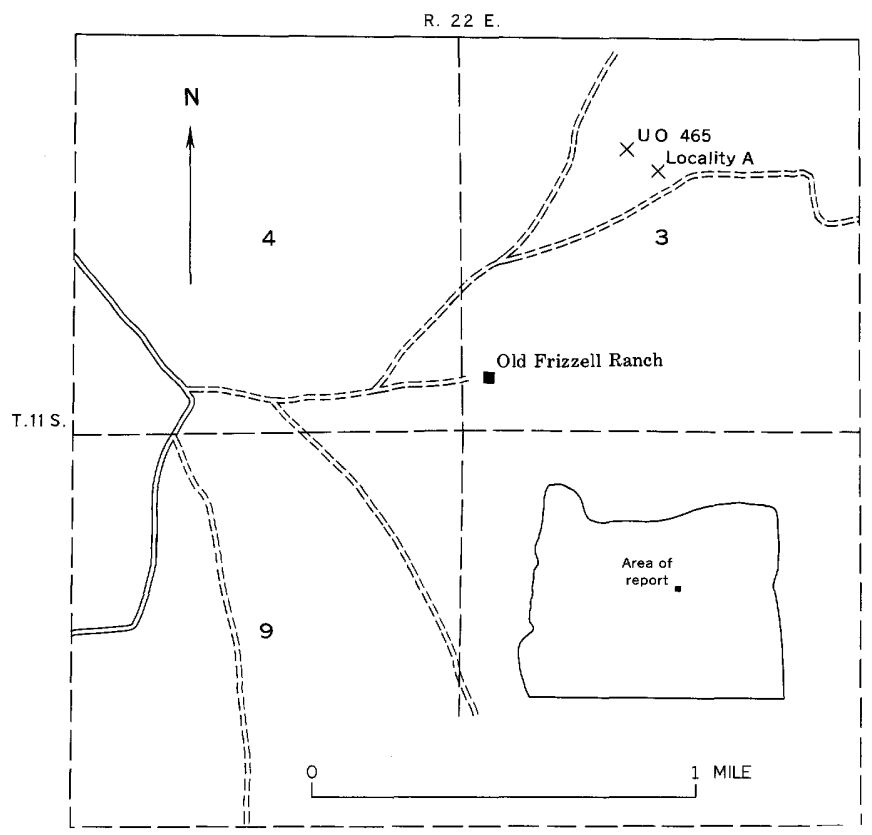

Figure 3.-Index map of Mitchell area, central Oregon, showing location of University of Oregon locality 465 and locality A (which includes USGS Mesozoic locs. 15801, 26262, 26378, M 2284, and UO loc. 4082).

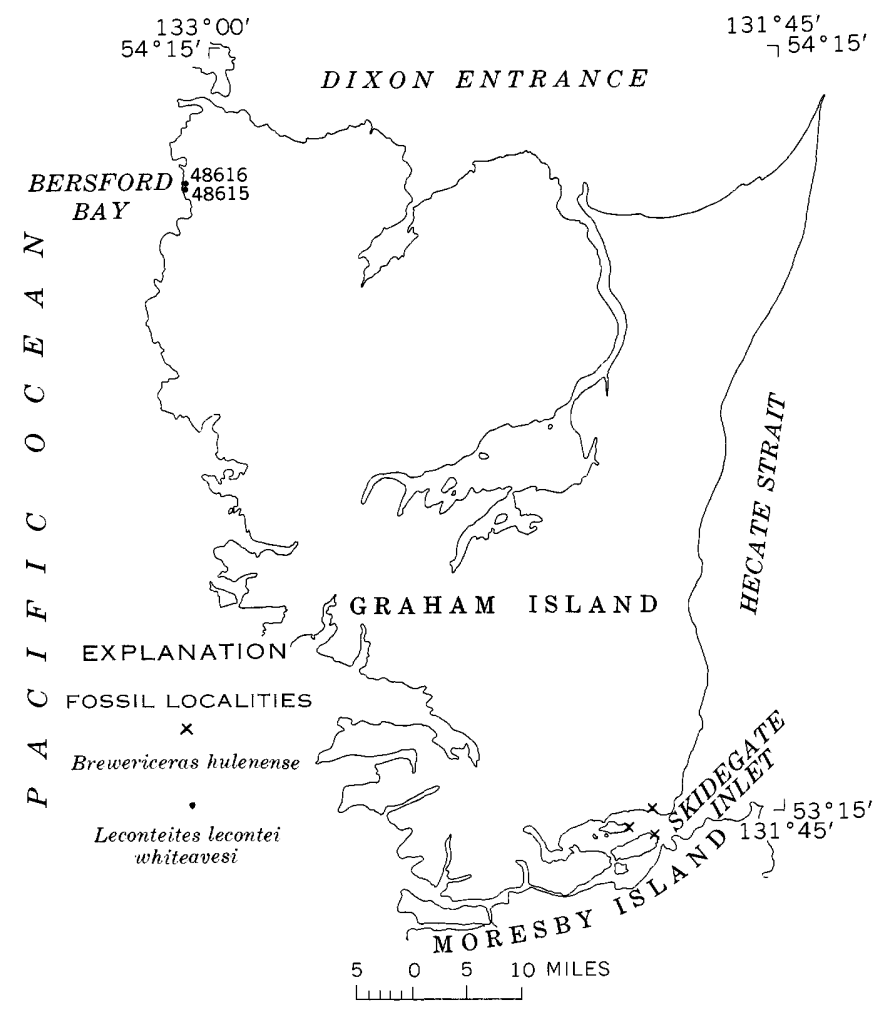

Figure 4.--Index map of Graham Island, Queen Charlotte Islands, B.C., showing localities where specimens of Brewericeras hulenense and Leconteites lecontei whiteavesi $\mathrm{n}$. subsp. were obtained.

nearby islands (Whiteaves, 1876). Study of the fossils from this sequence is in progress by F. H. McLearn, of the Geological Survey of Canada, and by D. L. Jones, who recently collected from this region.

The basal Albian beds in Skidegate Inlet contain Brewericeras hulenense and other species, but Leconteites is unknown. This absence is puzzling, as Whiteaves (1893, p. 441) reported that the type specimen of $L$. deansi was obtained from Skidegate Inlet. Leconteites is known from the north end of Graham Island at Beresford Bay, but these specimens appear to be closer to $L$. lecontei than to $L$. deansi.

In Skidegate Inlet, Brewericeras hulenense occurs with the following species:

Cleoniceras sp.
Douvilleiceras $\mathrm{spp}$.
Grantziceras $\mathrm{sp}$.
Arcthoplites belli McLearn
Puzosia alaskana Imlay
Anagaudryceras sp.
Parasilesites sp.
Tetragonites $\mathrm{sp}$.

This assemblage shows similarities to that of the Brewericeras hulenense zone of California, but also has forms that are abundant in southern Alaska and in the western interior of Canada. 
At Beresford Bay, L. lecontei whiteavesi n. subsp. occurs with Aucellina sp., Anagaudryceras cf. $A$. aurarium (Anderson), and Phyllopachyceras sp.

\section{SOUTHERN ALASKA}

Strata bearing Leconteites and Brewericeras are widespread in the upper Chitina Valley region, southern Alaska (fig. 5). Fossils from there have been figured by Imlay (1960), and the stratigraphy of the beds in the McCarthy A-4 quadrangle was described by Jones and Berg (1964).

Leconteites deansi occurs near the base of the Cretaceous sedimentary sequence (fig. 6) in association with the following forms, among others (see Imlay, 1960, p. 91):

Moffitites robustus Imlay

Kennicottia bifurcata Imlay

Anagaudryceras aurarium (Anderson)

Phyllopachyceras ef. $P$. shastalense (Anderson)

Calliphylloceras ef. C. aldersoni (Anderson)

Ptychoceras cf. P. laeve (Gabb)

Aucellina $\mathrm{sp}$

As shown in the columnar section (fig. 6), Moffitites robustus and Leconteites deansi are restricted to the basal sandstone unit in the Fohlin Creek area. In shale a few feet above the top of the sandstone, a single specimen of Leconteites having well-developed umbilical bullae was found associated with Aucellina. This specimen is referred to L. lecontei. The upper beds of this shale and siltstone unit contain scarce specimens of Brewericeras. Elsewhere in the upper Chitina Valley, beds of the Brewericeras hulenense zone are present and abundantly fossiliferous (Jones and Berg, 1964). Associated with $B$. hulenense are (see also Imlay, 1960, p. 91):

Phyllopachyceras chitinanum Imlay

Hypophylloceras ef. $H$. californicum (Anderson)

Calliphylloceras nizinanum Imlay

Anagaudryceras cappsi (Imlay)

Tetragonites sp.

Puzosia alaskana Imlay

Valdedorsella? whiteavesi Imlay

Desmoceras sp. juv.

Parasilesites bullatus Imlay

$P$. irregularis Imlay

Hulenites cf. $H$. reesidei (Anderson)

Cleoniceras overbecki Imlay

Arcthoplites belli McLearn

Arcthoplites talkeetnanus (Imlay)

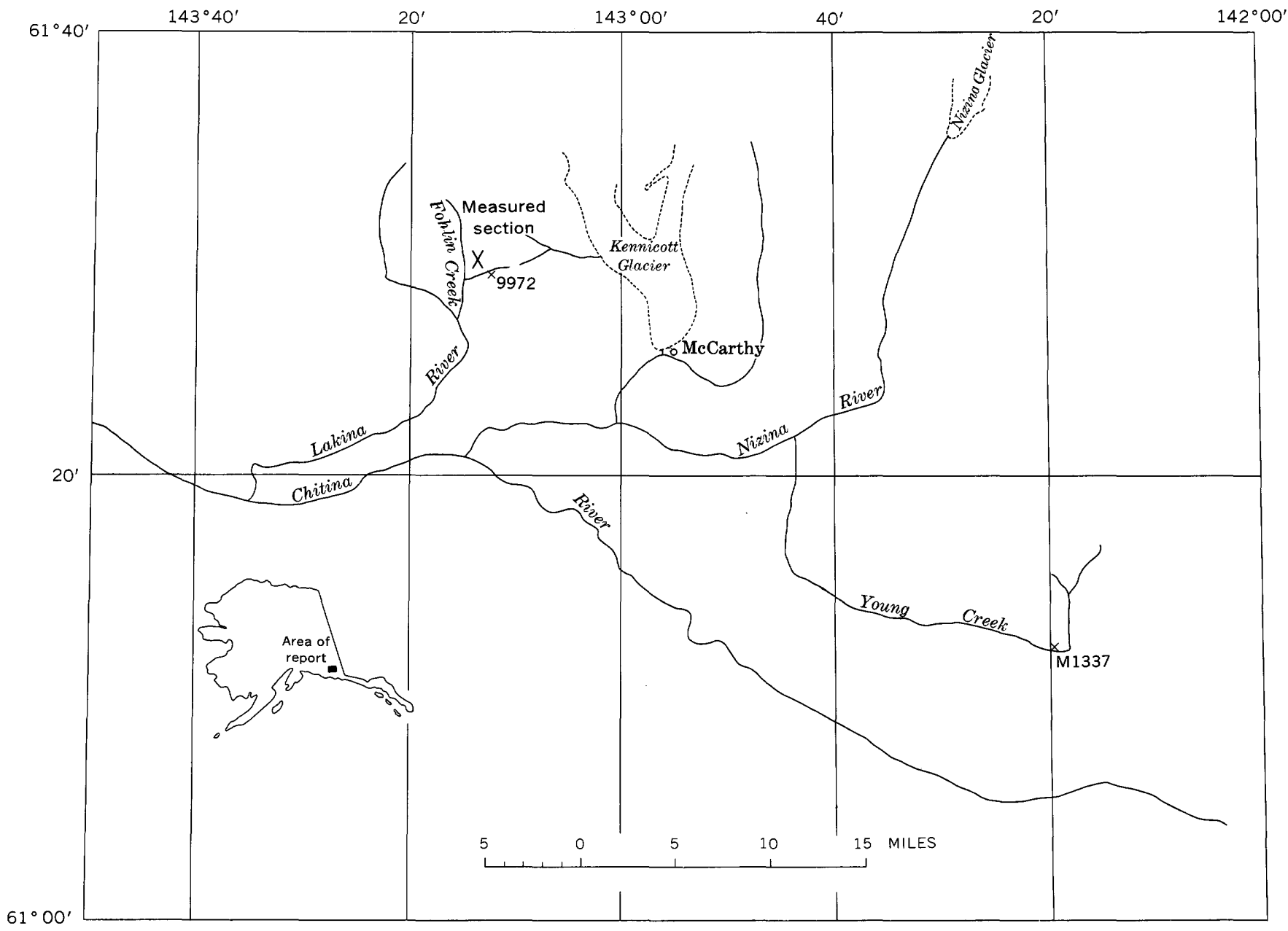

Frgure 5.-Index map of the upper Chitina Valley, southern Alaska. 


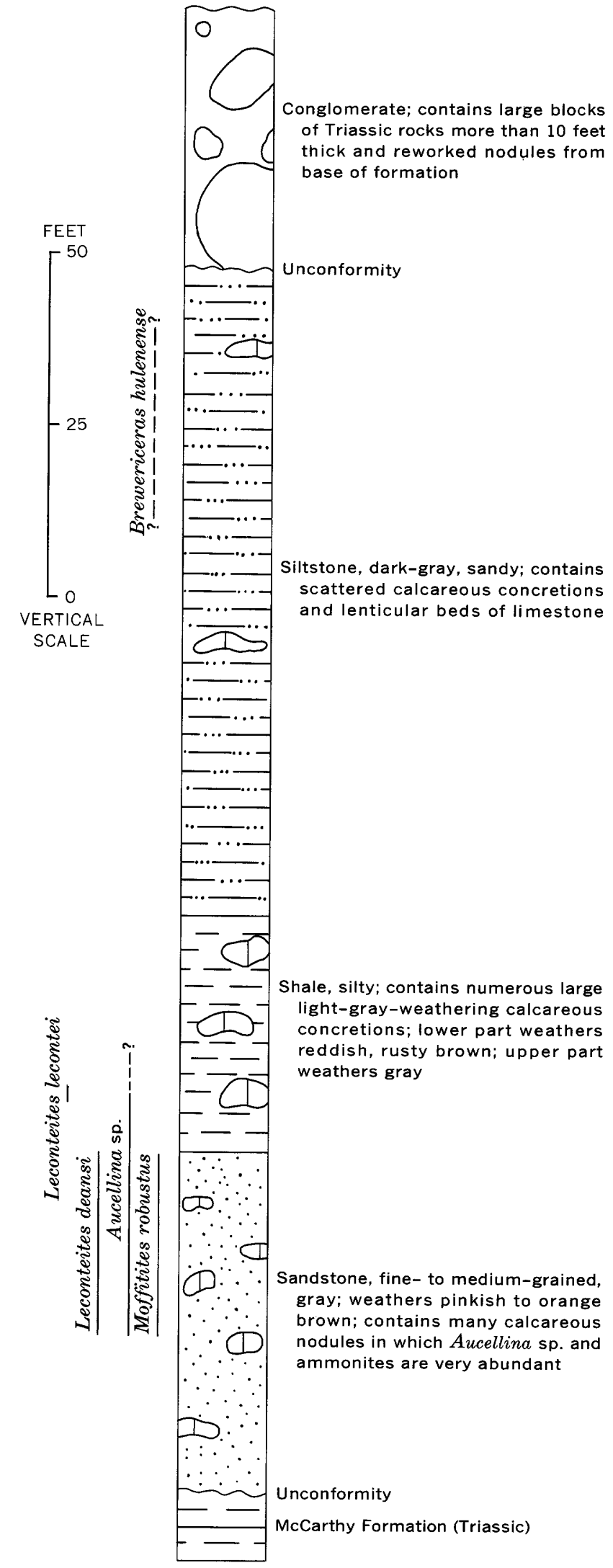

FigURE 6.-Generalized composite columnar section, Fohlin Creek area, upper Chitina Valley, southern Alaska, showing ranges of early Albian fossils.
Grantziceras glabrum (Whiteaves)

G. affine (Whiteaves)

Douvilleiceras cf. D. mammillatum (Schlotheim)

Freboldiceras singulare Imlay

This fauna is of particular importance as it contains a mixture of species known from the western interior of Canada along with those known from the Pacific faunal realm. In particular, Grantziceras (=Beudanticeras of authors) glabrum and G. affine, Arcthoplites belli, and Freboldiceras are abundant in Albian deposits in the Rocky Mountain foothills of western Canada. Apparently the connection between these two provinces was through northern Alaska, as Grantziceras occurs in several places in the Alaskan Arctic (Imlay, 1961, p. 57). The farthest known southern penetration of elements of this interior fauna is the Queen Charlotte Islands. Specimens of $B$. hulenense from USGS Mesozoic locality M1337 (fig. 5) are shown on plate 10.

\section{EVOLUTIONARY SEQUENCE}

The postulated evolutionary sequence of Leconteites and Brewericeras is shown in figure 7.L. deansi is considered to be the oldest representative of the genus and to have given rise to $L$. lecontei through emphasis of umbilical bullae. Ancestors of Leconteites have not yet been recognized. The change from Leconteites to Brewericeras was effected by the loss of umbilical bullae, simplification of ribbing, a tendency for excentric growth, and the development of a more deeply incised and interlocking suture. No descendants of Brewericeras have been recognized.

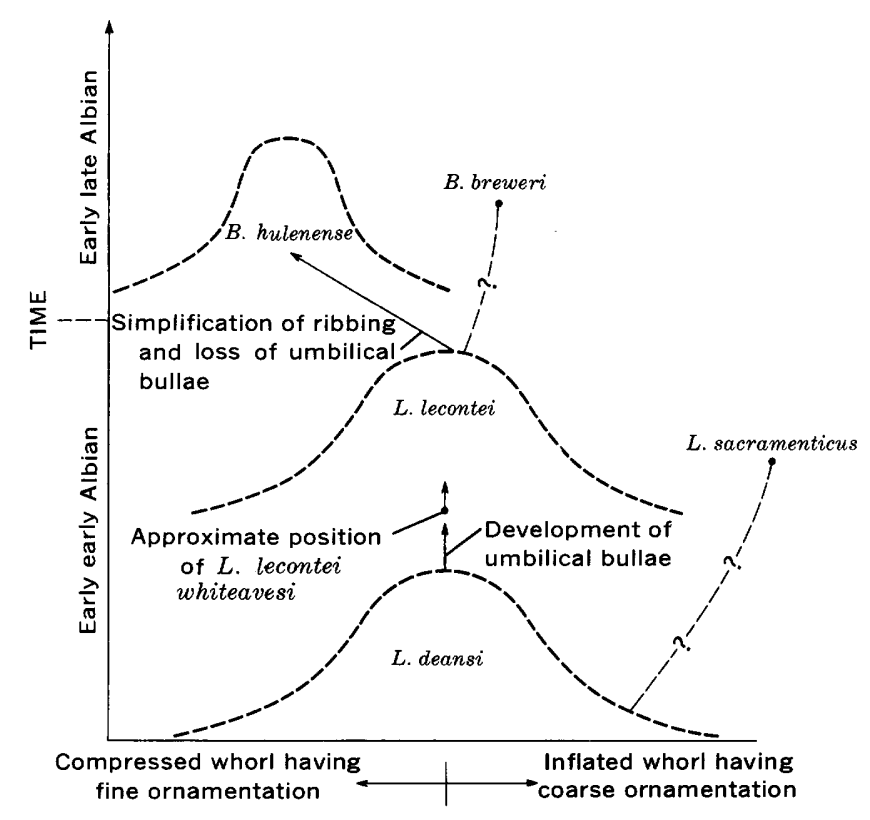

Figure 7.-Postulated evolutionary sequence of Leconteites and Brewericeras. Bell-shaped curves represent hypothetical adult populations that show a wide range in morphologic variation. 
Because of the close affinities of Leconteites and Brewericeras, their differentiation by Wright (1957) into two different families, Hoplitidae (subfamily? Cleoniceratinae) for the former and Desmoceratidae (subfamily Beudanticeratinae) for the latter, cannot be maintained. Both forms are herein referred to the family Desmoceratidae, subfamily Beudanticeratinae.

\section{SYSTEMATIC DESCRIPTIONS}

Family DESMOCERATIDAE

Subfamily BEUDANTICERATINAE

Genus LECONTEITES Casey

1954. Leconteites, Casey, Washington Acad. Sci. Jour., v. 44, no. 4, p. 110.

Type species (by original designation).-Desmoceras lecontei Anderson, 1902.

Synonomy.-Puzosigella Casey, 1954, iden.

\section{REVISED GENERIC DESCRIPTION}

Shell small to moderate in size, compressed to moderately inflated, and ratio of whorl breadth to whorl height ranges from about 0.52 to more than 1.10 . Umbilicus moderately narrow, ranging from 17 to 30 percent of diameter, with umbilical wall vertical to subvertical and shoulder abruptly rounded or angular on compressed specimens. Ornamentation consists of flexed primary ribs that arise singly on umbilical wall (pl. 6, fig. 16) or that spring singly in pairs or in bundles from umbilical bullae (pls. 3 and 4). Ribs project forward on ventrolateral area and tend to weaken and disappear on ventral shoulder; secondary ribs split off from primary ribs above midflank, and some intercalate freely between primary ribs; constrictions variably developed or absent, and peripheral collars characteristic of desmocerids are present on some specimens. Suture line consists of massive asymetrically bifid first lateral saddle, irregularly trifid and deep first lateral lobe; thin and shallow second lateral lobe; and auxiliary saddles that descend obliquely to umbilical seam.

Puzosigella is herein regarded as a subjective synonym of Leconteites because the characters that separate the generic type Pachydiscus sacramenticus from $L$. lecontei are deemed to be, at most, of only specific importance. The main differences shown by $P$. sacramenticus are a more rounded umbilical shoulder and the lack of umbilical tubercles at a late growth stage. Other species assigned to Puzosigella by both Casey and Imlay clearly intergrade with $L$. leconte $i$; however, among our specimens from Oregon, none were found that are similar to $P$. sacramenticus so it cannot be proved that that intergrading plexus ever produced the form of the typical Puzosigella. Among the California collections, a few specimens similar to $P$. sacramenticus are known, but these likewise cannot be demonstrated to intergrade with $L$. leconte $i$. It seems likely that the sacramenticus form is simply an extremely scarce product of the $L$. lecontei strain and thus could be repressed as a nominal species, but in the absence of definite proof of this relationship, we permit the species to stand as Leconteites sacramenticus but suppress Puzosigella as an unnecessary proliferation.

Leconteites deansi (Whiteaves), which is closely allied to $L$. lecontei, differs from that species also by lacking well-developed umbilical tubercles at all growth stages (see Imlay, 1960, p. 109, pl. 19, figs. 7-14). In other morphologic features, such as general whorl shape, nature of ribbing, and suture line, these three specieslecontei, sacramentica, and deansi-are similar, and they form a closely related group to which the generic name Leconteites is applicable.

\section{Leconteites lecontei (Anderson) s. s.}

Plate 1, figures 1-3, 6-11, 13-22; plate 2, figures 1-8, 10-14, 17,21 ; plate 3 ; plate 4 ; plate 5 ; plate 11 , figures $4-6$; and text figures 8-13.

1902. Desmoceras lecontei Anderson, California Acad. Sci. Proc., v. 2 , no. 1 , p. 95 , pl. 3 , figs. 94 , 95; pl. 10, fig. 190 .

1916. Sonneratia rogersi Hall and Ambrose, Nautilus, v. 30, p. 69,70 .

1929. Sonneratia rogersi Hall and Ambrose. Wiedey, Nautilus, v. 44 , p. 25 , pl. 2 , fig. 2 .

1938. Cleoniceras lecontei (Anderson). Anderson, Geol. Soc. America Spec. Paper 16, p. 192, pl. 38, fig. 4; pl. 47, figs. 3, 4.

1938. Cleoniceras modestum Anderson [in part], idem, p. 193, pl. 50, figs. 3, 4 .

1938. Sonneratia mulleri Anderson, idem, p. 195, pl. 51, fig. 4; pl. 54, figs. 3, 4.

1938. Sonneratia taffi Anderson, idem, p. 194, 195, pl. 49, figs. 4, 5.

1954. Leconteites lecontei (Anderson). Casey, Washington Acad. Sci. Jour., v. 44, no. 4, p. 110.

1954. Puzosigella mulleri (Anderson). Casey, idem.

1954. Puzosigella taffi (Anderson). Casey, idem.

1954. Puzosigella rogersi (Anderson). Casey, idem.

1960. Leconteites lecontei (Anderson). Imlay, U.S. Geol. Survey Prof. Paper 354-D, p. 109, pl. 19, figs. 1-3.

1960. Leconteites modestus (Anderson). Imlay, idem, p. 109, pl. 19, figs. 4-6.

1960. Puzosigella ef. $P$. rogersi (Hall and Ambrose). Imlay, idem, p. 108, pl. 19, figs. 33-35.

1938. [not] Cleoniceras modestum Anderson, Geol. Soc. America Spec. Paper 16, pl. 50, fig. 2 (CAS holotype 8870), 1938. [not] Sonneratia perrinsmithi Anderson, idem, pl. 51. fig. 6 (CAS paratype 8883).

Leconteites lecontei $\mathrm{s}$. s. shows an extreme range of morphologic variation and the named "species" cited above are merely variants within an intergrading series. Nearly all morphologic features, such as whorl shape, width of umbilicus, and strength of ornamentation are variable, and few specimens are identical. 
The whorl section varies progressively from compressed $(\mathrm{B} / \mathrm{H}$ ratio of $0.50-0.60)$ to inflated $(\mathrm{B} / \mathrm{H}$ ratio of 0.90 to more than 1.0); the compressed forms have flat convergent flanks, an abruptly rounded venter that tends to be flattened, a narrow steplike umbilicus (equal to 20-25 percent of the diameter) that has vertical umbilical walls and an angular umbilical margin and inconspicuous umbilical bullae and fine ribs. In forms having a more inflated whorl section, the flanks and venter are more rounded, the umbilicus is wider (equal to 26 to more than 30 percent of the diameter), has sloping walls and a rounded shoulder, and the umbilical bullae are larger and the ribs coarser (fig. 8). Every transitional stage can be observed between the compressed forms and the inflated forms, and no natural subdivisions into two or more categories can be established on the basis of whorl proportions or strength of ornamentation (figs. 9, and 10 and following measurements). Of a sample of 38 measurable specimens from locality $\mathrm{A}$ in central Oregon, about 8 percent have a $\mathrm{B} / \mathrm{H}$ ratio between 0.50 and $0.59,60$ percent have a ratio between 0.60 and 0.79 , and 32 percent have a ratio of 0.80 or greater. These proportions are probably
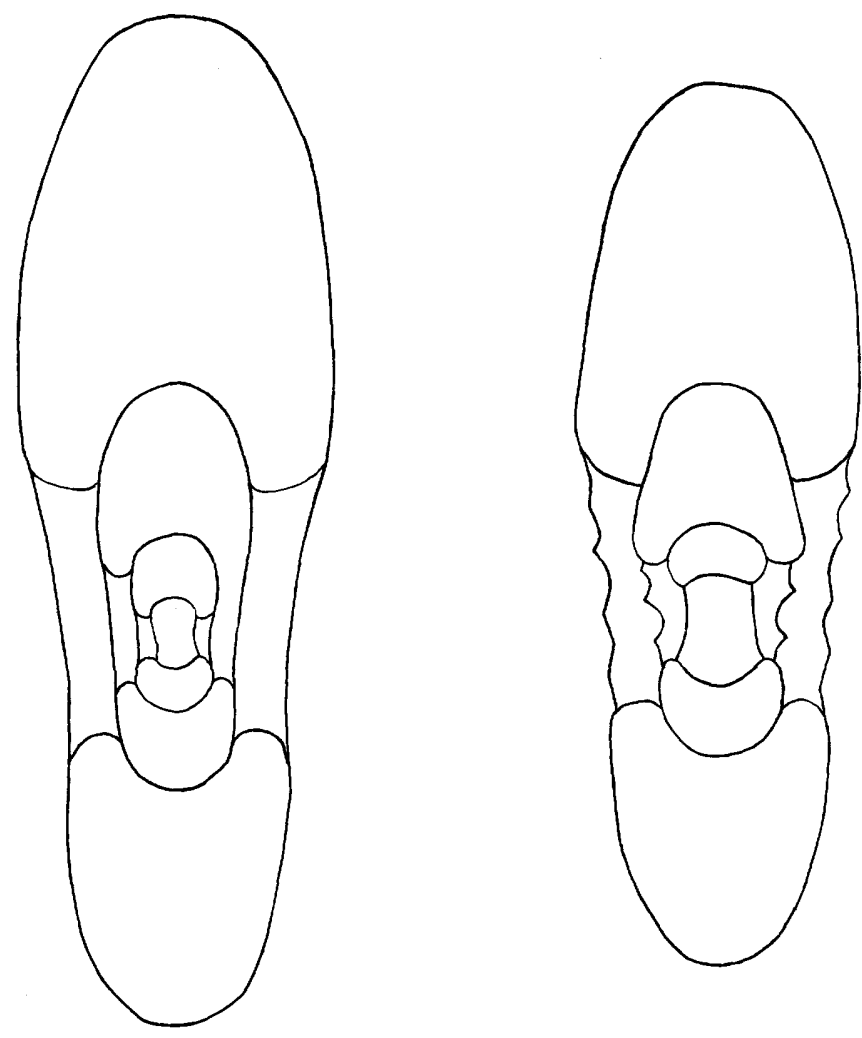

Figure 8.-Cross sections of Leconteites lecontei $i$ s. s. from locality A, central Oregon. Figure $A$, hypotype, USNM 121525a; weakly ribbed form $(\times 3)$. Figure $B$, hypotype, USNM $121525 b$, moderately ribbed form $(\times 3)$. greatly influenced by collecting failures and perhaps by unknown sorting influences, but a general impression given by all known collections is that the extremely inflated forms with a $\mathrm{B} / \mathrm{H}$ ratio of 1.00 or greater are scarce.

Ornamentation consists of bundled ribs that spring obliquely forward from umbilical bullae, although some bullae bear only single ribs, and an occasional rib rises freely on the lower part of the flank. Small umbilical bullae first appear at a diameter of about $3 \mathrm{~mm}$; at a whorl height about $4 \mathrm{~mm}$, faint ribs extend obliquely from these across the flank. The ribs have a falcate course across the flanks, project strongly forward on the outer flank, and tend to weaken on both the lower flank and the venter. Secondary ribs bifurcate from the main ribs near or above midflank or are intercalated freely between primary ribs on the outer third of the flanks. The number of secondary ribs per primary rib is highly variable. Finely ribbed compressed forms may have five or more secondary ribs, and more coarsely ribbed inflated forms may have only one or two. Constrictions are present on some specimens and absent on others. Because some individuals have constrictions only during a particular growth stage, no particular taxonomic significance can be placed on their presence or absence.

A progressive series of changes in ornamentation can be traced from finely ribbed forms (for example, pl. 3, figs. 1-3) to very coarsely ribbed forms (pl. 4, figs. $33-35$ ), and clearly defined, distinct groups within this series cannot be delimited. The specimens illustrated on plates 3 and 4 are arranged so that their progressive changes can be traced step-by-step. On plate 3, ornamentation becomes coarser from the upper lefthand corner to the lower right-hand corner; on plate 4, the ornamentation becomes coarser from top to bottom. Umbilical bullae on finely ribbed forms are indistinct swellings along the umbilical margin. On coarsely ribbed forms, umbilical bullae are very prominent. On some specimens (pl. 3, fig. 45), early whorls are bullate but later whorls have only indistinct swellings along the umbilical shoulder. Most specimens of L. lecontei, however, show some indication of umbilical bullae, however faint, in contrast to $L$. deansi (Whiteaves), in which they are only rarely and weakly developed.

The suture lines of L. lecontei $\mathrm{s}$. s. are shown in figures 11-13. No essential difference is seen between the suture of the compressed form (figs. 11, 12) and that of the more inflated form (fig. 13). The ventral lobe is broad and has a low bifid saddle; the first lateral lobe is wide, very deep, and trifid; the first saddle is massive, high, and bifid; the second lateral lobe is narrow and shallow; auxiliary saddles rapidly decrease in size and descend abruptly to the umbilical seam. 


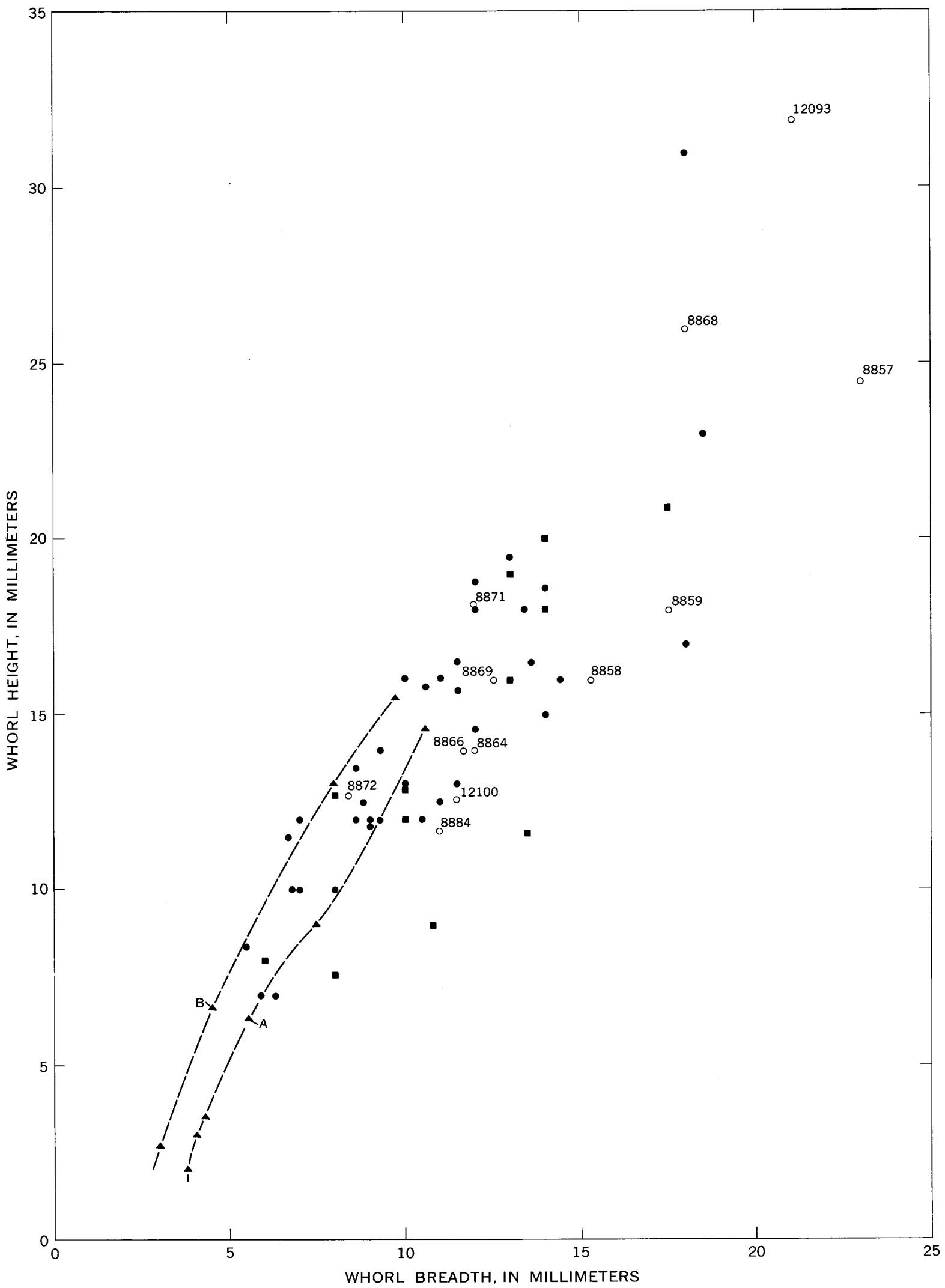

FIGURE 9.-Scatter diagram showing relation of whorl height to whorl breadth in Leconteites lecontei s. s. Black dots are specimens from locality A, central Oregon. Triangles and dashed lines connect measurements of single specimens from this same locality. Open circles refer to Anderson's type specimens. Squares are selected specimens from northern California. 


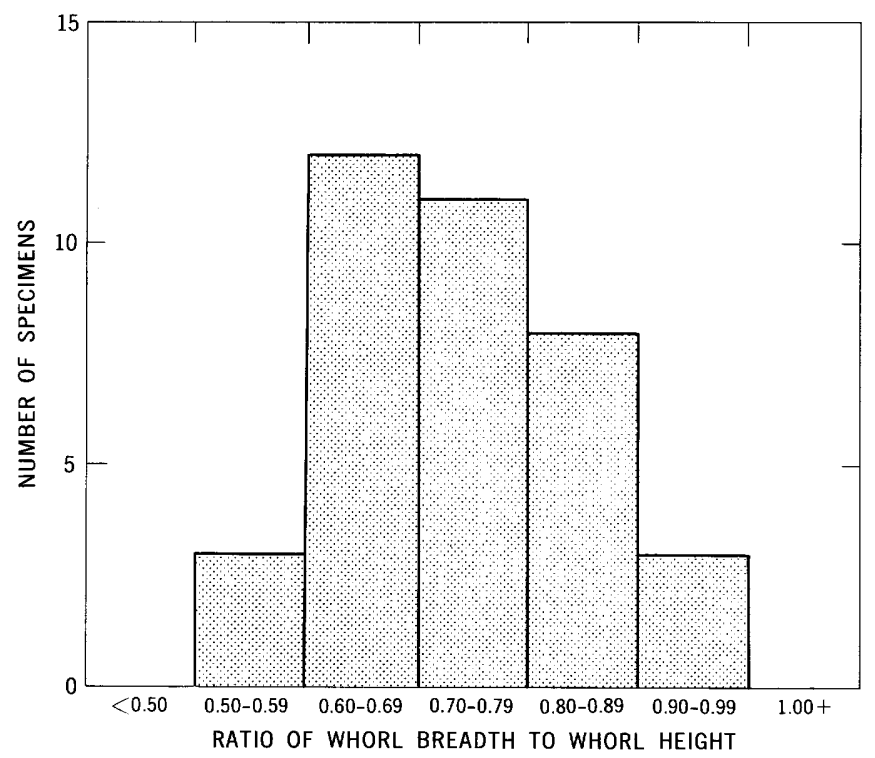

Figure 10.-Bar graph showing frequency distribution of ratio of whorl breadth to whorl height for specimens of Leconteites lecontei s. s. from locality A, central Oregon.

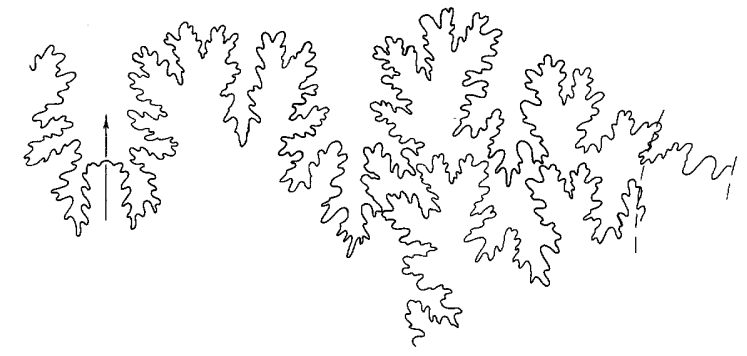

Figure 11.-Suture line of finely ribbed specimen of Leconteites lecontei s. s., hypotype, USNM 121499 from USGS Mesozoic locality 15801. Specimen figured on plate 3 , figures $42-44(\times 3)$.

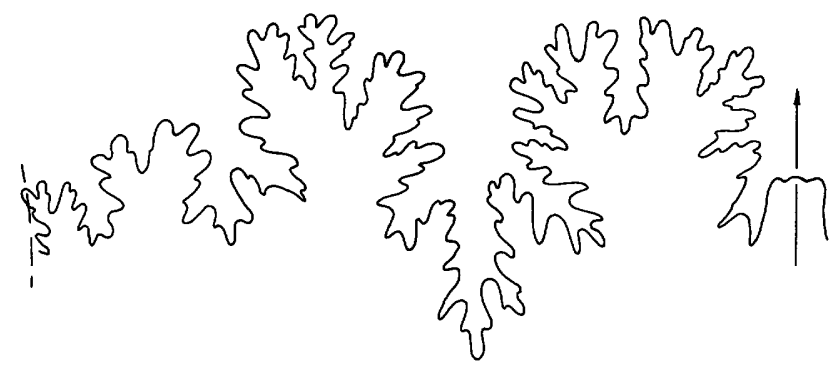

FIGURE 12.-Suture line of weakly ribbed example of Leconteites leconteis.s. Hypotype USNM 121490 from USGS Mesozoic locality 26262. Specimen figured on plate 3, figures 13-15 $\left(\times 5 \frac{1}{2}\right)$.

Two specimens referred by Anderson to species herein regarded in part as synonyms of $L$. lecontei do not belong to this species. The holotype of Cleoniceras modestum Anderson (1938, pl. 50, fig. 2; CAS 8870) has widely spaced falcate ribs, slightly inflated convergent flanks, a narrow umbilicus having a steep wall, and a narrowly

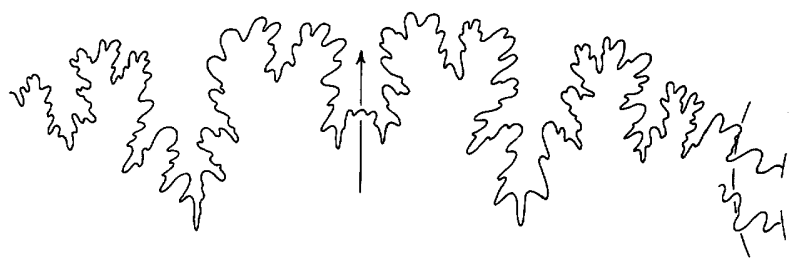

FIGURE 13.-Suture line of moderately ribbed example of Leconteites lecontei s. s. Hypotype, USNM 121503 from University of Oregon locality 465; specimen figured on plate 4, figures 9-11 (X 31/2).

rounded venter. This form is fairly close to Beudanticeras newtoni Casey (see Casey, 1961, p. 147). The other specimen, a paratype (CAS 8883) of Sonneratia perrinsmithi (pl. 1, figs. 4, 5, and 12), has perisphinctid ribbing consisting of primary ribs that rise on the umbilical wall, project obliquely forward on the lower flank, bend slightly backward at midflank, and split on the outer flank into two or three secondary ribs that cross the venter with only a very slight forward projection and without a tendency to weaken at midventer. Periodic weak sinuous constrictions are also present. The proper generic placement of this form is not clear, and no additional specimens are known to the writers.

Measurements, in millimeters, of selected groups of specimens from California and from USGS Mesozoic locality 26262, central Oregon

[Whorl height and breadth data are plotted in fig. 9]

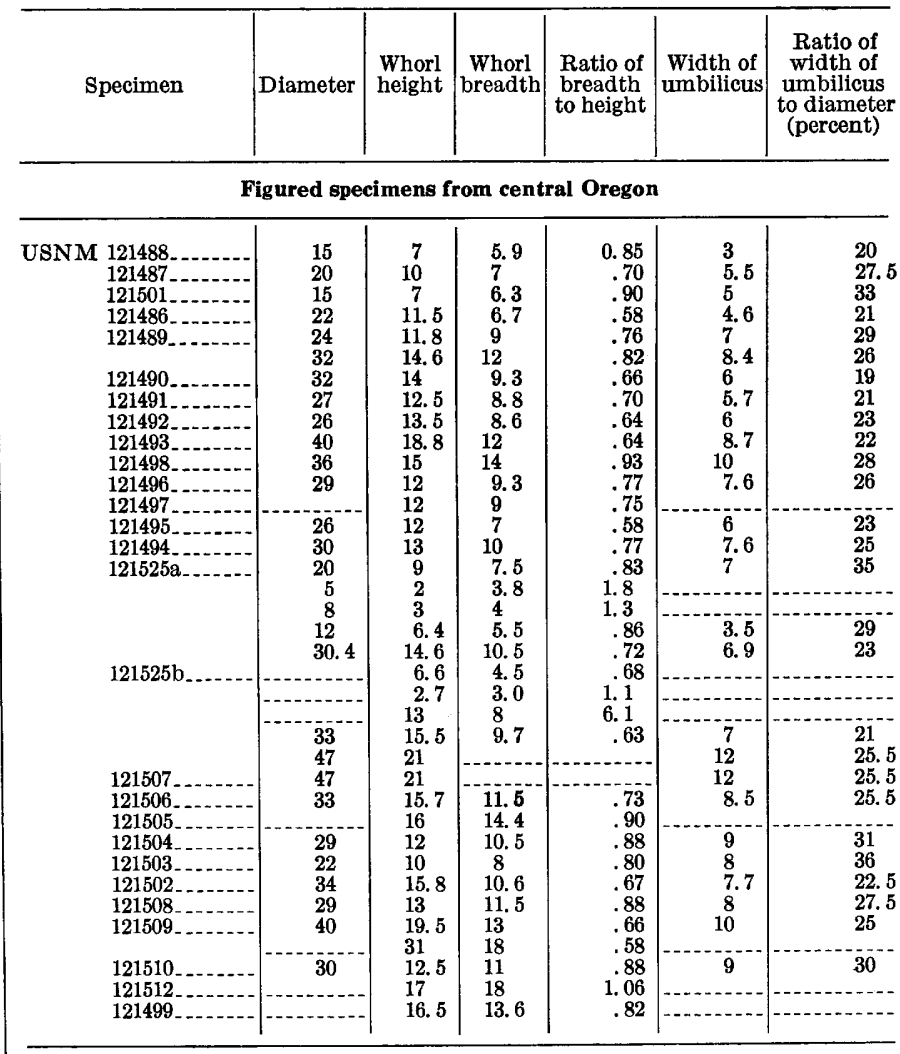


Measurements, in millimeters, of selected groups of specimens from California and from USGS Mesozoic locality 26262 , central Oregon-Continued

\begin{tabular}{l|l|c|c|c|c|c}
\hline Specimen & Diameter & $\begin{array}{c}\text { Whorl } \\
\text { height }\end{array}$ & $\begin{array}{c}\text { Whorl } \\
\text { breadth }\end{array}$ & $\begin{array}{c}\text { Ratio of } \\
\text { breadth } \\
\text { to height }\end{array}$ & $\begin{array}{c}\text { Width of } \\
\text { umbilicus }\end{array}$ & $\begin{array}{c}\text { Ratio of } \\
\text { width of } \\
\text { umbilicus } \\
\text { to diameter } \\
\text { (percent) }\end{array}$ \\
\hline \\
\hline
\end{tabular}

Anderson's figured specimens of Leconteites spp. and Puzosigella sp.

\begin{tabular}{|c|c|c|c|c|c|c|c|}
\hline CAS & 8858 & & & & 0.97 & 13 & \\
\hline & 8859- & $\begin{array}{l}43 \\
36\end{array}$ & 18 & 17.5 & .97 & 12 & 28 \\
\hline & & & 24.5 & 23 & .93 & $\begin{array}{l}11 \\
19\end{array}$ & \\
\hline $\begin{array}{l}\text { UC } \\
\text { CAS }\end{array}$ & $\begin{array}{l}12093 \\
8868\end{array}$ & $\begin{array}{l}62 \\
59\end{array}$ & 32 & $\begin{array}{r}21 \\
118\end{array}$ & .66 & $\begin{array}{l}13 \\
14\end{array}$ & ${ }_{23,5}^{21}$ \\
\hline & $8871-$ & $\begin{array}{l}09 \\
42\end{array}$ & 18 & 12 & . 67 & 10 & 24 \\
\hline $\mathrm{UC}$ & $\begin{array}{l}8869 \\
12100\end{array}$ & $\begin{array}{r}35 \\
1100\end{array}$ & $\begin{array}{l}16 \\
45\end{array}$ & $\begin{array}{l}12.5 \\
36\end{array}$ & .78 & $\begin{array}{r}7 \\
31\end{array}$ & $\begin{array}{l}20 \\
31\end{array}$ \\
\hline $\mathrm{CAS}$ & 886 & 33 & 14.0 & $\begin{array}{l}11.0 \\
11.7\end{array}$ & .81 & 10 & \\
\hline & 8884 & 29 & 11.7 & 11 & .94 & 9 & \\
\hline & unumbered. & 39 & 18 & $\begin{array}{l}8.4 \\
14\end{array}$ & $\begin{array}{l}.06 \\
.78 \\
\end{array}$ & $\begin{array}{l}6 \\
9\end{array}$ & 23 \\
\hline
\end{tabular}

Figured specimens of Leconteites lecont ei from Huling Creek

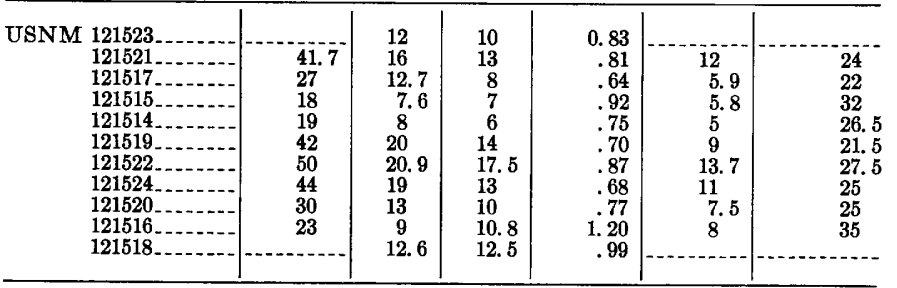

1 About.

Measurements of selected groups of specimens are shown above and whorl height and breadth data are plotted in figure 9. Measured and illustrated specimens from Oregon include only those from locality A of figure 3; specimens from California were selected from three stratigraphic levels (fig. 2), near the base, the middle, and the top of the Leconteites-bearing sequence on Huling Creek. Several specimens from each level were chosen to demonstrate that the full range of morphologic variation from compressed to inflated forms occurs throughout the known range of the species. No attempt is made to thoroughly document the complete intergradation at each level, as this would only duplicate the sequence shown by the Oregon specimens.

Holotype: UC 12093.

Type locality: CAS loc. 152, east branch of Huling Creek, northern California.

Figured specimens: USNM 121486-121510, 121512-121524, $121525 \mathrm{a}, \mathrm{b}, 121537$, CAS $8866,8884,8882,8858,8857,8868$, $8872,8871,8869,8864$, UC 12093, Stanford Univ. paleont. type colln. 511 .

Geologic age: Early Albian, zone of Leconteites lecontei.
Leconteites lecontei whiteavesi Jones, Murphy, and Packard, n. subsp.

Plate 6, figures 1-9, 12-14; plate 7, figures 1-3

Specimens of Leconteites from Beresford Bay, Queen Charlotte Islands, were recently collected by A. Sutherland-Brown, of the British Columbia Departmen t of Mines and Petroleum Resources, and made available for study through the courtesy of F. H. McLearn of the Geological Survey of Canada. These specimens are closely related to typical Leconteites lecontei but differ by subtle features of ornamentation and by attaining a larger size. Although the weakly ornamented forms from Queen Charlotte Islands are nearly identical to those from California and Oregon (pl. 6, figs. 1-3), the more coarsely ribbed forms (pl. 6, figs. 12-14; pl. 7) have less strongly developed umbilical bullae from which primary ribs arise singly rather than in bundled pairs; none of the 15 specimens available to the writers have strong umbilical bullae, although they show a moderate range in variation of strength of ribbing. Some of the small specimens or early whorls of larger specimens (for example, pl. 6, figs. 12-14) have nearly smooth lower flanks, which is rare in typical forms of $L$. leconte $i$; they also have a slightly more rounded umbilical shoulder.

The Queen Charlotte Islands specimens also differ from Alaskan specimens of Leconteites referred to $L$. deansi. The main differences are the presence in the former of weak umbilical bullae and the tendency of the ribbing on the inner and outer flanks to be clearly separated by a band on which ribbing is weak, in contrast to the latter, which lacks umbilical bullae and has ribs that tend to thicken slightly on the lower or middle flank.

The specimen shown on plate 7 is the largest example of Leconteites known to the writers; it exceeds by more than $80 \mathrm{~mm}$ the maximum diameter of specimens known to us from California or Oregon. This size difference may not be specifically important, but it seems worthy of note that of the 15 specimens available to us from the Queen Charlotte Islands, 6 specimens, or fragments, exceed the maximum size known for typical $L$. leconte $i$.

This new subspecies is named in honor of $\mathrm{J}$. F. Whiteaves, who described many of the Cretaceous fossils known from the Queen Charlotte Islands.

Measurements, in millimeters, of specimens from Queen Charlotte Islands

\begin{tabular}{|r|r|r|r|r|r|c}
\hline GSC specimen & Diameter & $\begin{array}{c}\text { Whorl } \\
\text { height }\end{array}$ & $\begin{array}{c}\text { Whorl } \\
\text { breadth }\end{array}$ & $\begin{array}{c}\text { Ratio of } \\
\text { breadth } \\
\text { to height }\end{array}$ & $\begin{array}{c}\text { Width of } \\
\text { unbilicus }\end{array}$ & $\begin{array}{c}\text { Ratio of } \\
\text { width of } \\
\text { umbilicus } \\
\text { to diameter } \\
\text { (percent) }\end{array}$ \\
\hline 19098 & & & & & & \\
\hline 19099 & 19 & 14 & 0.74 & 8 & 20 \\
19100 & 17 & 8 & 6.3 & .79 & 3.6 & 21 \\
19101 & 53 & 10.7 & 6.9 & .64 & 5.5 & 24 \\
19097 & 33 & 16.4 & 11 & .67 & 7.4 & 22.5 \\
\hline
\end{tabular}


Types: Holotype GSC 19097; paratypes GSC 19098-19102. Type locality: GSC loc. 48615, Beresford Bay, Queen Charlotte Islands.

Figured specimens: Types cited above.

Geologic age: Early Albian.

\section{Leconteites sacramenticus (Anderson)}

Plate 2, fgures 9, 15, 16, 18-20

1902. Pachydiscus sacramenticus Anderson, California Acad. Sci Proc., v. 2, no. 1, p. 105, pl. 6, figs. 133, 134; pl. 10, fig: 105.

1938. Sonneratia sacramentica (Anderson). Anderson, Geol. Soc. America Spec. Paper 16, p. 195, pl. 49, figs. 1-3.

1954. Puzosigella sacramentica (Anderson). Casey, Washington Acad. Sci. Jour., v. 44, no. 4, p. 110.

Leconteites sacramenticus, the generic type of Puzosigel$l a$, is questionably distinct from Leconteites leconte $i$. The shell is moderately inflated, has rounded flanks, a broadly rounded venter, a moderately wide umbilicus, and a steeply sloping umbilical wall. Early whorls, to a diameter of $30-35 \mathrm{~mm}$, have prominent primary ribs that rise from thickened elongate umbilical bullae and that cross the flanks with a gently flexed course. At or just above midflank, the primary ribs bifurcate into secondary ribs that project moderately forward on the outer flank and weaken on the venter. As the shell diameter increases, umbilical bullae disappear and ribs on the lower flanks weaken progressively so that, on large shells, only bundled striae can be seen. Ribbing on the outer flank remains fairly strong and projects forward, but differentiation into primary and secondary ribs is lost. An occasional rib crosses the venter, but most ribs split up into two to five fine striae. Very faint spiral lines are on the venter of the holotype, and the intersection of these and the transverse striae produce a faint reticulate pattern.

Leconteites sacramenticus is a very scarce form and is known only from Anderson's type specimens. No specimens from Oregon exhibit the same combination of characteristics, nor can any of the known specimens of L. lecontei from Huling Creek be shown to intergrade with these forms. We feel that this lack of intergradation is due probably to an insufficient collection of specimens, but in the absence of definite proof of this, it seems best to regard $L$. sacramenticus as a distinct species. No necessity is seen, however, for the genus Puzosigella, and it is herein considered as a subjective synonym of Leconteites. Measurements of the holotype and paratype are given on page $\mathrm{F} 13$ and are shown in figure 10.

Holotype: UC 12100.

Paratype: CAS 8859.

Type locality: CAS loc. 152.

Figured specimens: UC 12100, CAS 8859.

Geologic range: Probably from Leconteites lecontei zone judging from nature of preservation and from Anderson's locality information.

\section{Leconteites deansi (Whiteaves) \\ Plate 6, figures 10, 11, 15, 16}

1893. Olcostephanus (Astieria) deansi Whiteaves, Canadian Record Sci., ser. 1, v. 10, sec. 14, p. 442-444, pl. 7, figs. 1, 1 a. 1960. Leconteites deansi (Whiteaves). Imlay, U.S. Geol. Survey Prof. Paper 354-D, p. 109, pl. 19, figs. 7-14.

1960. Leconteites cf. L. deansi (Whiteaves). Imlay, idem, p. 109, pl. 19, figs. 15-17.

1960. Leconteites modestus (Anderson). Imlay, idem, p. 109, pl. 19, figs. 4-6.

1960. Puzosigella cf. $P$. rogersi (Hall and Ambrose). Imlay, idem, p. 109, pl. 19, figs. 33-35.

Leconteites deansi is very abundant in the lowermost Cretaceous beds of the upper Chitina Valley. Recent collecting there by Imlay and Jones has shown that the specimens figured by Imlay (1960) as Puzosigella cf. P. rogersi, $L$. deansi, $L$. cf. $L$. deansi, and $L$. modestus actually intergrade and form one variable species. This species differs from $L$. leconte $i$ by lacking umbilical bullae and by having ribs that rise singly at or near the umbilical seam, even on the more coarsely ribbed variants. In an occasional specimen, two ribs may join near the umbilical shoulder (see Imlay, 1960, pl. 19, fig. 20), producing what appears to be a small bulla at the junction. This condition is probably pathologic. The ribs tend to become slightly stronger on the lower flank before splitting into two or more secondary ribs, in contrast to $L$. lecontei, in which the ribs weaken with the formation of a nearly smooth band on the lower flank.

The previously determined stratigraphic position of this species requires minor revision. According to Imlay (1960, fig. 21), Leconteites modestus and Puzosigella spp. questionably occur below $L$. deansi and Moffitites robustus Imlay. Further collecting has demonstrated that all of these forms herein referred to $L$. deansi are found together with $M$. robustus and that these occur below a specimen that has well-developed umbilical bullae and that is referred to $L$. lecontei. Thus, $L$. deansi is the earliest known representative of Leconteites, and it appears to have given rise to $L$. leconte $i$ by emphasis of the umbilical bullae.

The type locality of $L$. deansi is unknown; according to Whiteaves $(1893$, p. 442$)$ the original specimen sent to him for study was labeled as having been collected at Skidegate Inlet, Queen Charlotte Islands. Recent extensive collecting at this place by Jones failed to turn up any specimens of this species nor were any fossiliferous Cretaceous rocks older than the Brewericeras hulenense zone found there. Specimens of Leconteites lecontei are known from the northwestern side of Graham Island, however, no specimens of $L$. deansi have yet been found there.

Figured specimen: Hypotype USNM 130164b from USGS Mesozoic loc. 9972.

Geologic age: Early Albian, zone of Moffitites robustus. 


\section{Genus BREWERICERAS Casey}

1954. Brewericeras, Casey, Washington Acad. Sci. Jour., v. 44, no. 4, p. 112 .

Type species (by original designation).-Ammonites breweri Gabb, 1864, pl. 10, fig. 7 ([not] 1869, pl. 20, fig. 5, as cited by Casey. That specimen is herein referred to $B$. hulenense).

The genus Brewericeras was established for Pacific coast Albian ammonites that were previously assigned to Beudanticeras. They differ from Beudanticeras by having

* * * very flat, subparallel whorl sides, consistently sharp umbilical rim, and no constrictions or peripheral ridges. Costate developments with falciform ribs on the upper lateral area that are sharper and more regular than those of Beudanticeras and which weaken on the ventral area (Casey, 1954, p. 112).

Study of large collections of specimens from northern California and southern Alaska necessitates a revision of the generic characteristics described above. A revised generic description follows:

The shell is compressed and has flat to slightly inflated flanks, a narrow evenly rounded venter, a small umbilicus having an abrupt to very sharp umbilical shoulder and a steeply sloping to vertical wall. Ornamentation consists of falcate ribs of varying strength that commonly arise from bundled striae on the lower flank but that rarely arise singly at the umbilical margin or spring from inconspicuous umbilical bullae. The ribs are most prominent on the outer flank, where they project strongly forward, and they may weaken or be indistinguishable on the venter. Constrictions are scarce, although more coarsely ribbed forms tend to have a few falcate constrictions that are bordered on the venter by a posterior peripheral ridge.

Other species referred by Casey to Brewericeras include Ammonites haydeni Gabb and Beudanticeras hulenense Anderson. According to Murphy and Rodda (1960, p. 851-852), A. haydeni is a true representative of Beudanticeras and differs markedly from Brewericeras hulenense by nature of the suture, whorl shape, and ornamentation.

Brewericeras thus includes two species, breweri and hulenense, and these have been consistently confused. In Casey's citation of the type species, he designated $B$. breweri as the type, but he referred to a specimen that we regard as $B$. hulenense. This misidentification, however, does not have any significant effect on the generic concept, as the two species do not differ greatly.

Brewericeras is clearly closely related to Leconteites and could, indeed, be regarded as of no more than subgeneric rank or even regarded as a synonym, but we prefer to retain both generic names. The differences between Leconteites and Brewericeras are summarized as follows:
Brewericeras

Whorl shape mainly thin and compressed; moderately inflated forms are rare.

Ornamentation ranges from completely smooth to strong primary falcate ribs that rarely bifurcate on outer flank; umbilical tubercles and paired ribs are absent; constrictions are rare.

Coiling excentric

\section{Brewericeras breweri (Gabb) \\ Plate 8, figures 3, 5} tendency to excentricity on very compressed forms.

1864. Ammonites brewerii Gabb, California Geol. Survey, Paleontology, v. 1, p. 62, pl. 10, fig. 7.

1954. Brewericeras brewerii (Gabb). Casey, Washington Acad. Sci., v. 44, no. 4, p. 112.

1869. [not] Ammonites brewerii Gabb, California Geol. Survey, Paleontology, v. 2, p. 130, pl. 19, fig. 5, 6; pl. 20, fig. 5 . 1876. [not] Ammonites brewerii Gabb. Whiteaves, Mesozoic Fossils, p. 21, pl. 1, fig. 2, 2a, 3, 3a.

1927. [not] Beudanticeras breweri (Gabb). Crickmay, Amer. Jour. Sci., ser. 15, v. 13, no. 78, p. 503.

1938. [not] Beudanticeras breweri (Gabb). Anderson, Geol. Soc. America Spec. Paper 16, p. 189, pl. 43, fig. 3; pl. 44, figs. 1, 2.

1960. [not] Brewericeras breweri (Gabb). Imlay, U.S. Geol. Survey Prof. Paper 354-D, p. 105, pl. 17, figs. 5-10, 12, 13.

Brewericeras breweri was originally obtained from the North Fork of Cottonwood Creek, northern California, and the holotype is the only known specimen of this species. This specimen, which is a fragment of a body whorl that has a part of the inner whorl exposed, is crushed and deformed and cannot be accurately measured. The whorl section is compressed and its height is greater than its breadth; the whorl appears to be somewhat inflated and its greatest breadth is in the lower one-third of the flank. Some of this inflation may be due to secondary deformation, but the flanks do not appear to be as slab sided as in $B$. hulenense. The umbilicus is fairly wide, the umbilical wall nearly vertical, and the umbilical shoulder abrupt. The suture line is unknown.

Ornamentation consists of fairly strong regular falcate ribs that rise on the umbilical shoulder, project forward on the lower flank, bend backward at midflank, and again project forward on the outer flank. The ribs cross the venter and have only a slight tendency to weaken along the midline. Likewise, ribbing on the lower flank tends to be only slightly less prominent than on the outer flank, and a few ribs bundle together on approaching the umbilical shoulder. 
The ribs of this specimen extend to the umbilical shoulder and in this respect differ from the closely allied $B$. hulenense, in which the ribbing is absent or very weak on the lower flank. Many specimens of $B$. hulenense are as coarsely ribbed on the outer flank as $B$. breweri, but on all of these specimens the ribs tend to be weak on the lower flank, although on some of the more inflated varieties, an occasional rib may reach the umbilical margin. Also, the ribs are stronger on the venter and the flanks more inflated in $B$. breweri than in $B$. hulenense. These differences are more those of degree than of kind, however, and it would seem logical to treat these two "species" as belonging to a single, highly variable, intergrading population and to repress $B$. hulenense as unnecessary. However, among hundreds of specimens examined, no clear transition from one form to the other was found, and B. breweri seems to be unique. Unfortunately, the stratigraphic position of this species is unknown, and until additional specimens are found and their relationship to $B$. hulenense established, it seems best to regard the two forms as separate species.

Holotype: UC 12098.

Type locality: North Fork of Cottonwood Creek, northern California; exact position unknown.

Age: Probably late early Albian. This judgment is based on the position of $B$. hulenense, its congener, and the character of the attached matrix, which is like that of the B. hulenense zone of Huling Creek.

\section{Brewericeras hulenense (Anderson)}

Plate 8, figures 1, 2, 4; plates 9, 10; plate 11, figures 1-3, 13-14

1876. Ammonites brewerii Gabb. Whiteaves, Mesozoic Fossils, v. 1, pt. 1, p. 21, pl. 1, fig. 2, 2 a.

1927. Beudanticeras brewerii Gabb. Crickmay, Am. Jour. Sci., 5th ser., v. 13 , no. 78 , p. 509, figs. 1-3.

1938. Beudanticeras hulenense Anderson, Geol. Soc. Ameica Spec. Paper 16, p. 190, pl. 44, figs. 3, 4.

1938. Beudanticeras breweri (Gabb). Anderson, idem, p. 189, pl. 43, fig. 3 ; pl. 44, figs. $1,2$.

1943. Desmoceras haydeni Gabb. Anderson, Calif. Div. Mines Bull. 118, p. 168-169, figs. 61-68.

1960. Brewericeras breweri (Gabb). Imlay, U.S. Geol. Survey Prof. Paper 354-D, p. 105, pl. 17, figs. 5-10, 12, 13.

1960. Brewericeras cf. B. hulenense (Anderson). Imlay, idem, p. 106, pl. 17, figs. 11, 14-16.

1960. Brewericeras hulenense (Anderson). Murphy and Rodda, Jour. Paleontology, v. 34, no. 5, pl. 105, fig. 3.

Brewericeras hulenense is widespread in Albian deposits of the Pacific coast region of North America and occurs in California, Oregon, Washington, Queen Charlotte Islands, B.C., and southern Alaska. Throughout this extent the species exhibits similar morphologic characteristics that show a wide range in variation.

Typical specimens of $B$. hulenense are nearly smooth and have flattened, nearly parallel flanks, an evenly rounded narrow venter, and a small umbilicus having a sharp shoulder and a steep to vertical wall. Excentric growth is well displayed in some specimens (pl. 10; pl. 11, figs. 1, 13; text fig. 14). At a diameter of approximately $45 \mathrm{~mm}$ and larger, the umbilical wall is bent midway between the umbilical suture and the umbilical edge so that it appears to have been creased. The growth lines on the wall are inclined posteriorly from the umbilical suture to this crease and then inclined anteriorly from the crease to the umbilical shoulder giving the growth lines a chevron shape on the umbilical wall. This characteristic is useful in distinguishing fragmentary specimens of $B$. hulenense from Beudanticeras haydeni on which the chevron shape of the growth lines is lacking. Ornamentation consists of bundled growth striae that rise at the umbilical seam, are curved on the wall as described above, inclined strongly forward on lower flanks, arch gently backward at midflank and cross the upper flanks with marked forward projection.

Like Leconteites lecontei, Brewericcras hulenense shows an extremely wide range of variation from very compressed smooth forms to inflated strongly

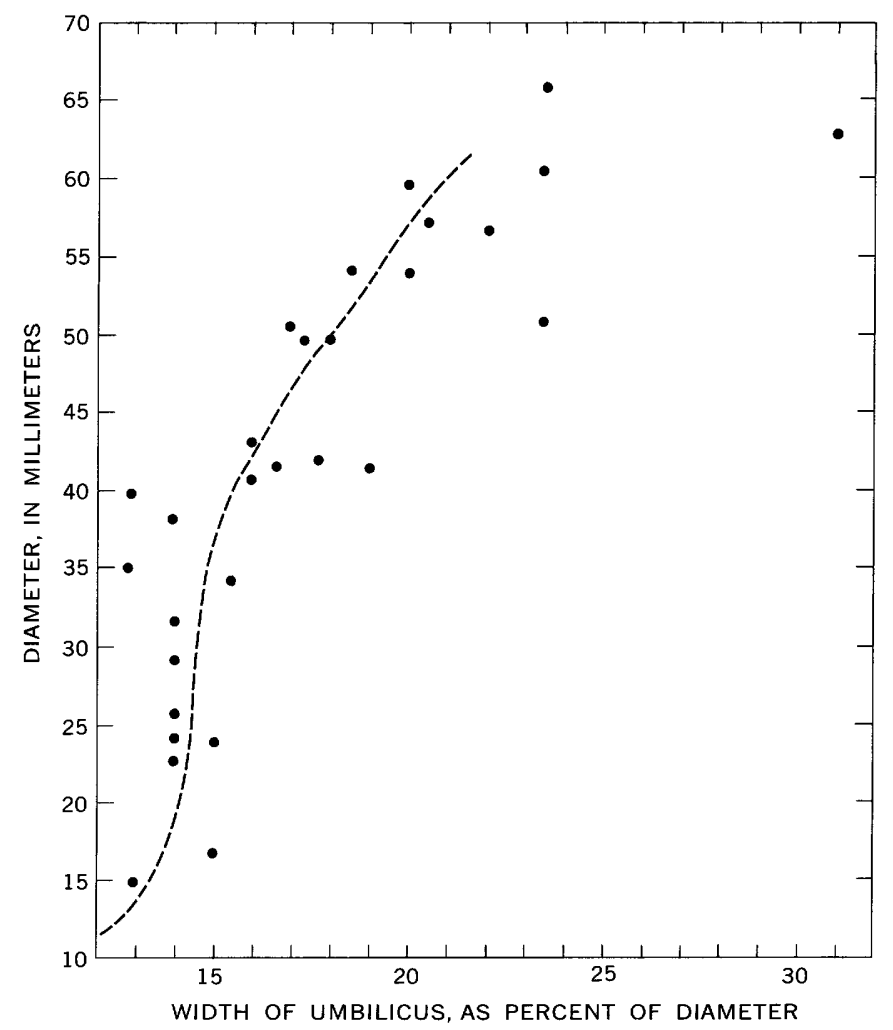

FIGURE 14.-Scatter diagram showing relation of width of umbilicus, expressed as percent of diameter, to diameter for specimens of Brewericeras hulenense from USGS Mesozoic locality M1337. A relative increase in umbilical width due to excentric growth is shown by the change in slope of the curve at about a diameter of $30 \mathrm{~mm}$. The heavy dots represent more coarsely ribbed specimens. 
ribbed specimens (pl. 10). Costation when present commonly develops at a diameter of about $35 \mathrm{~mm}$. The costae are low, closely spaced, most strongly developed on the outer half of the flanks, and weak or absent across the venter and on the umbilical half of the flank. In some large specimens, periodic widely spaced ridges, associated with constrictions of the shell, are present on the flanks and venter. Some specimens show a slight tendency toward bundling of the striae at the umbilical edge, but bullae are not developed as on species of the closely related Leconteites.

An intergrading series that has progressively stronger ornamentation can be demonstrated from the nearly smooth specimens shown on plate 9 , figure 4 , and plate 10 , figure 1 , through typical forms that have weak ornamentation as represented by the holotype and by the specimens figured on plate 10 , figures 3 to 5 , to the coarsely ribbed specimen shown on plate 10 , figures 14,15 . Correlated with the increase in coarseness of the ribbing is an increase in the $\mathrm{B} / \mathrm{H}$ ratio and in the width of the umbilicus. In addition, the whorl section becomes more rounded and the umbilical shoulder may become less sharp as the ribs increase in strength.

The suture line is deeply incised and moderately interlocked (figs. 15 and 16) and has a thin asymmetrically bifid first lateral saddle, a deep trifid first lateral lobe that is much deeper than the external lobe, and a very thin asymmetric second lateral saddle. Three irregular auxiliary saddles descend evenly to the umbilical seam. The internal suture consists of a moderately high arch that has numerous auxiliary saddles and lobes. The suture of $B$. hulenense differs from that of $L$. leconte $i$ by being more deeply incised and by having thinner stemmed saddles.

In a single population the frequency of occurrence of the coarsely ribbed forms similar to the specimen on

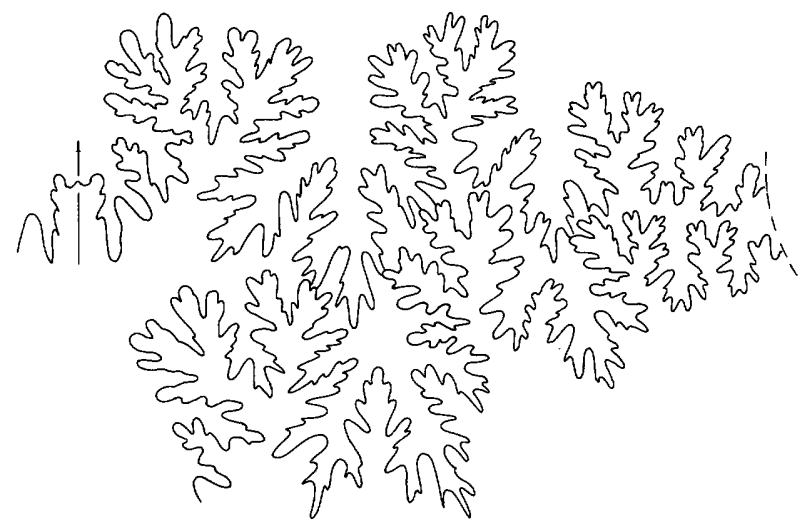

FIGURE 15.-Suture line of Brewericeras hulenense, hypotype USNM 121535, from University of California at Riverside locality 1000; specimen figured on plate 11, figures $1-3\left(\times 4 \frac{1}{2}\right)$.

plate 10 , figures 14 and 15 , is very low. In one sample from USGS Mesozoic locality M1337 consisting of more than 70 specimens, 38 specimens having a diameter of more than $35 \mathrm{~mm}$ are smooth or have only ill-defined riblets composed of bundled striae, 18 specimens have clearly discernible ribs, and only 1 specimen has coarse ribs (fig. 17). Because ribs do not appear on some specimens until a fairly large diameter $(55-60 \mathrm{~mm})$ is attained, these proportions may not be too precise, because some of the smaller specimens in the smooth group might ultimately have produced ribs, thus decreasing the difference in frequency of these two groups. Despite this, in all known collections, smooth to faintly or weakly ribbed forms greatly predominate over the more coarsely ribbed forms. A selected series of specimens from USGS Mesozoic locality M1337 are shown on plate 10 and measurements of 27 specimens are given in the table below.

Brewericeras hulenense is closely related to Leconteites lecontei, and differs from it mainly in details of

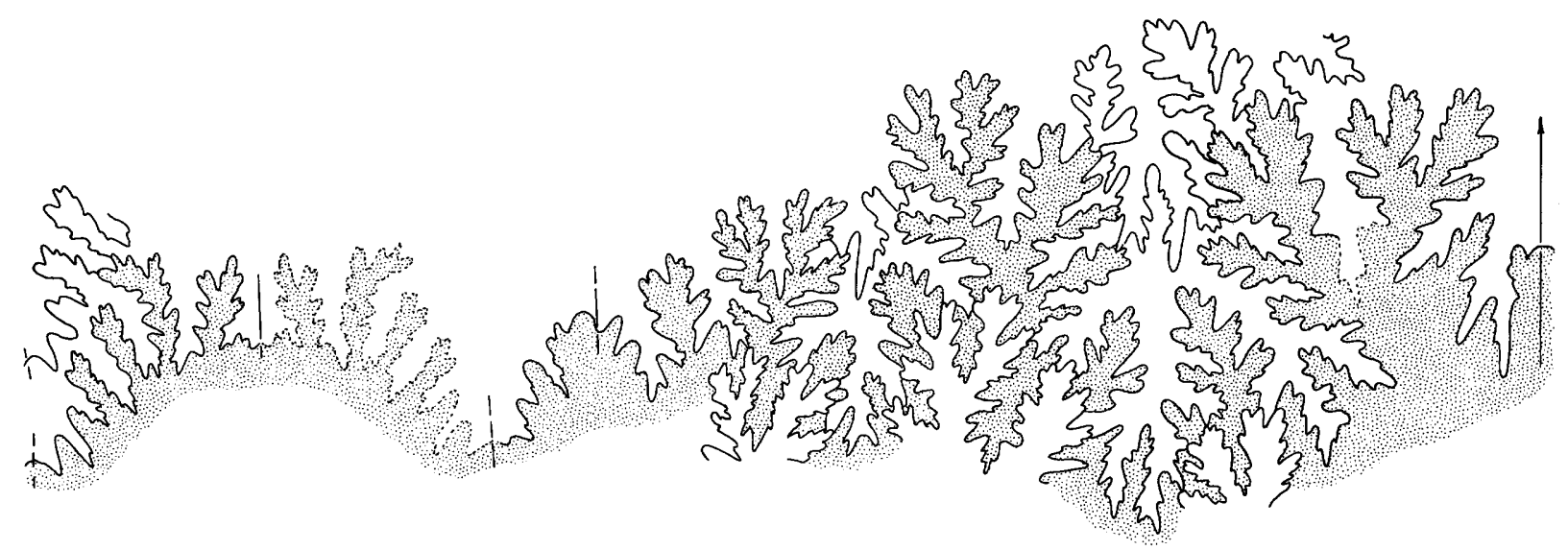

FIGURE 16.-Suture line of Brewericeras hulenense (Anderson); hypotype USNM 121511, from University of California at Riverside locality 70 ( $\left.\times 1 \frac{3}{4}\right)$. 

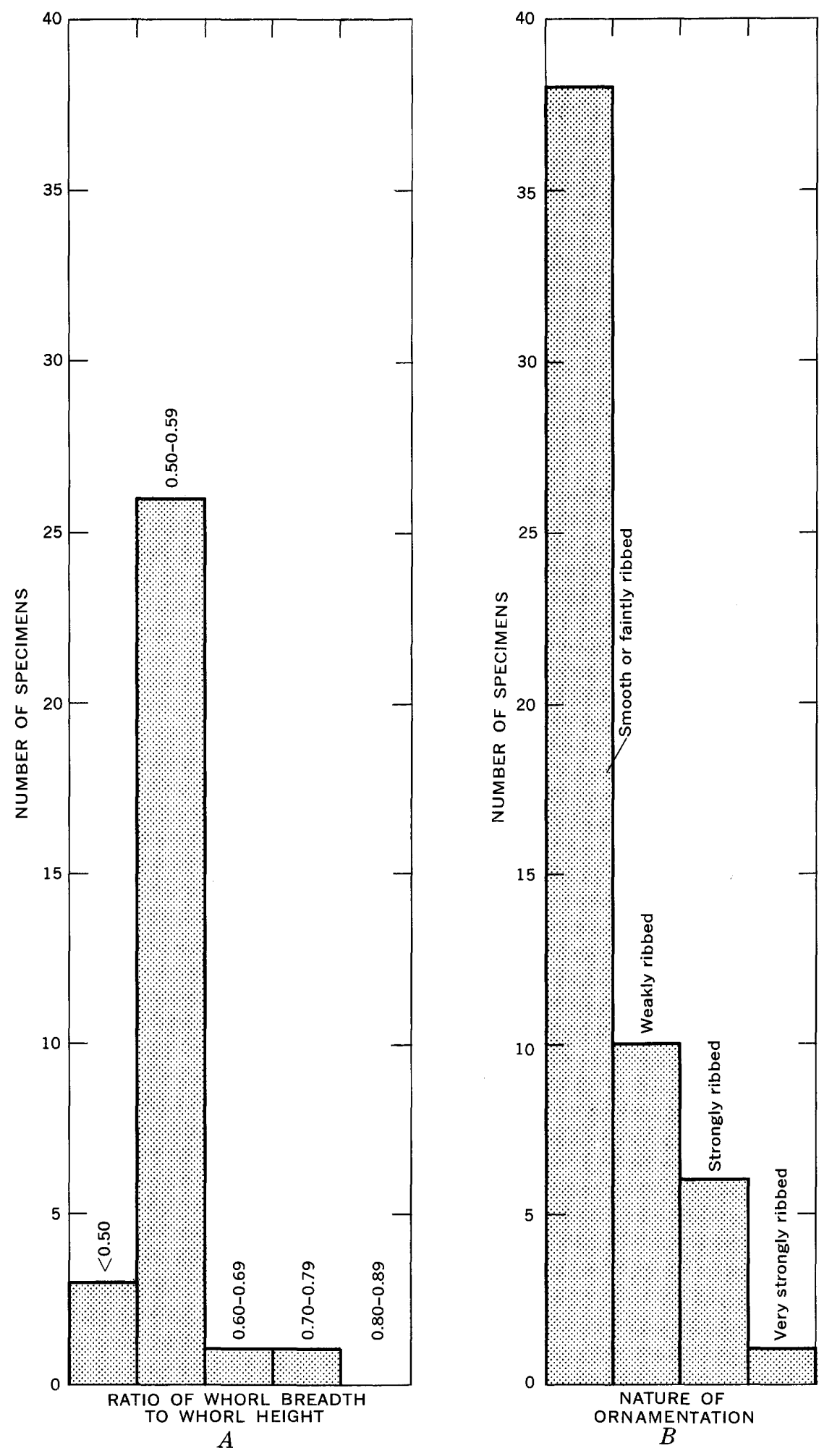

FIGURE 17,-A, Bar graph showing frequency distribution of whorl breadth to whorl height ratio in Brewericeras hulenense from USGS Mesozoic locality M1337. $B$, Bar graph showing frequency distribution of smooth and ribbed forms of Brewericeras hulenense from USGS Mesozoic locality M1337." 
ribbing. In $B$. hulenense, the ribs mainly rise singly on the lower flank or, in inflated forms, on the umbilical shoulder, and well-developed umbilical bullae are not present. These ribs do not bifurcate on the outer flank, and if secondary ribs are present, they rise singly between the primaries. In $L$. leconte $i$, the primary ribs tend to spring in pairs from well developed, pinched umbilical bullae and generally bifurcate on the outer flank. The strongly developed bifurcation of ribs in $L$. deansi clearly separates that species from $B$. hulenense.

In most collections of $B$. hulenense, the differences previously cited clearly separate it from the geologically older species $L$. lecontei. Among the collections from Huling Creek, however, there are some specimens that are clearly intermediate in form between the two genera, and their proper taxonomic position is difficult to determine. For example, the specimen on plate 11, figures 7 to 9 , has finer more numerous ribs on the outer flank than is usual for $B$. hulenense, and the umbilical bullae are only slightly weaker than is usual for $L$. lecontei (compare this specimen with the specimen of $L$. lecontei figured on pl. 11, figs. 4-6). The ribs of the outer whorl, however, show no indication of bifurcation and are similar to those of $B$. hulenense. The specimens on plate 11 , figures $10-12$ and 15-17, have strong umbilical bullae and bifurcating ribs of the Leconteites type on the inner whorls and coarse simple ribs of the $B$. hulenense type on the body chamber. These scarce specimens, which occur with the lowest known examples of $B$. hulenense and 10-15 feet above beds having undoubted $L$. lecontei (fig. 2), are considered as intermediate forms linking the two genera.

Holotype: CAS 8831.

Type locality: CAS loc. 1659. East Fork of Huling (= Hulen) Creek, Ono area, northern California.

Figured specimens: USNM 121526-121536 and ANSP 4798.

Geologic age: Brewericeras hulenense zone, upper lower Albian.

Measurements, in millimeters, of selected groups of specimens from California and USGS Mesozoic locality M1937, southern Alaska

\begin{tabular}{|c|c|c|c|c|c|c|}
\hline Specimen & Diameter & $\begin{array}{l}\text { Whorl } \\
\text { height }\end{array}$ & $\begin{array}{c}\text { Whorl } \\
\text { breadth }\end{array}$ & $\begin{array}{l}\text { Ratio of } \\
\text { breadth } \\
\text { to height }\end{array}$ & $\begin{array}{l}\text { Width of } \\
\text { umbilicus }\end{array}$ & $\begin{array}{l}\text { Ratio of } \\
\text { width of } \\
\text { umbilicus } \\
\text { to diameter } \\
\text { (percent) }\end{array}$ \\
\hline 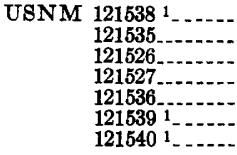 & $\begin{array}{l}45 \\
48 \\
64 \\
72 \\
65 \\
56 \\
42\end{array}$ & $\begin{array}{l}21.7 \\
21.8 \\
30 \\
37 \\
25 \\
24 \\
16.6\end{array}$ & $\begin{array}{c}13.6 \\
212.7 \\
19 \\
21 \\
18 \\
318 \\
14.6\end{array}$ & $\begin{array}{l}0.62 \\
.58 \\
.63 \\
.57 \\
.72 \\
.75 \\
.87\end{array}$ & \begin{tabular}{l|}
9 \\
12 \\
15 \\
10.8 \\
18 \\
15.8 \\
13.8
\end{tabular} & $\begin{array}{l}20 \\
20 \\
23.5 \\
15 \\
27.5 \\
28 \\
33\end{array}$ \\
\hline $\begin{array}{r}121528 \\
121532 \ldots \\
121529 \ldots \ldots \\
121533 \ldots \\
121531 \\
121534 \\
121530 \\
\text { LSJU } 6506 \\
\text { ANSP } 4798 . \ldots \\
\end{array}$ & $\begin{array}{r}139 \\
61 \\
54 \\
66 \\
57 \\
63 \\
65 \\
120 \\
113\end{array}$ & $\begin{array}{l}60 \\
28 \\
25.5 \\
29 \\
24 \\
25 \\
30 \\
49 \\
48\end{array}$ & $\begin{array}{l}38 \\
16 \\
13.5 \\
15 \\
13.5 \\
18 \\
15 \\
38 \\
33\end{array}$ & $\begin{array}{l}.63 \\
.63 \\
.57 \\
.53 \\
.52 \\
.56 \\
.72 \\
.50 \\
.77 \\
.68\end{array}$ & $\begin{array}{l}36 \\
14.5 \\
10 \\
17.5 \\
12.5 \\
19.8 \\
12.6 \\
33 \\
32\end{array}$ & $\begin{array}{l}26 \\
23.5 \\
18.5 \\
26.5 \\
22 \\
31 \\
19.4 \\
27.5 \\
20.5\end{array}$ \\
\hline
\end{tabular}

Measurements, in millimeters, of selected groups of specimens from California and USGS Mesozoic locality M1837, southern AlaskaContinued

\begin{tabular}{|c|c|c|c|c|c|c|}
\hline Specimen & Diameter & $\begin{array}{l}\text { Whorl } \\
\text { height }\end{array}$ & $\begin{array}{c}\text { Whorl } \\
\text { breadth }\end{array}$ & $\begin{array}{l}\text { Ratio of } \\
\text { breadth } \\
\text { to height }\end{array}$ & $\begin{array}{c}\text { Width of } \\
\text { umbilicus }\end{array}$ & $\begin{array}{l}\text { Ratio of } \\
\text { width of } \\
\text { umbulicus } \\
\text { to diameter } \\
\text { (percent) }\end{array}$ \\
\hline \multicolumn{7}{|c|}{ Unnumbered specimens } \\
\hline $\begin{array}{l}12 \\
2 \\
3 \\
5\end{array}$ & $\begin{array}{l}17 \\
23 \\
24 \\
24 \\
26 \\
29 \\
32 \\
34 \\
35 \\
38 \\
40 \\
41 \\
42 \\
42 \\
43 \\
44 \\
51 \\
51 \\
50 \\
54 \\
57 \\
50 \\
60 \\
64 \\
71 \\
15 \\
12\end{array}$ & $\begin{array}{r}8.0 \\
12.9 \\
12.9 \\
12.9 \\
13.6 \\
15.0 \\
16.8 \\
17.5 \\
18.1 \\
19.7 \\
20.0 \\
21.0 \\
20.0 \\
21.5 \\
21.5 \\
23.0 \\
23.0 \\
24.0 \\
24.0 \\
25.0 \\
26.0 \\
24.0 \\
27.5 \\
28.0 \\
30.5 \\
8.7 \\
7.0\end{array}$ & $\begin{array}{r}5.5 \\
7.3 \\
6.8 \\
7.2 \\
7.0 \\
7.7 \\
9.0 \\
10.0 \\
9.4 \\
10.5 \\
10.0 \\
10.1 \\
10.0 \\
10.5 \\
11.0 \\
10.5 \\
12.0 \\
12.5 \\
12.8 \\
13.9 \\
14.0 \\
12.0 \\
15.0 \\
16.0 \\
17.5 \\
4.7 \\
4.0\end{array}$ & $\begin{array}{l}0.69 \\
.57 \\
.53 \\
.56 \\
.52 \\
.52 \\
.53 \\
.57 \\
.52 \\
.53 \\
.50 \\
.48 \\
.50 \\
.49 \\
.51 \\
.46 \\
.52 \\
.52 \\
.53 \\
.55 \\
.54 \\
.50 \\
.55 \\
.57 \\
.57 \\
.54\end{array}$ & $\begin{array}{r}2.5 \\
3.2 \\
3.3 \\
3.5 \\
3.6 \\
4.1 \\
4.5 \\
5.5 \\
4.6 \\
5.3 \\
5.8 \\
6.5 \\
8.0 \\
6.5 \\
7.6 \\
6.6 \\
12.0 \\
8.7 \\
9.0 \\
10.7 \\
11.8 \\
8.8 \\
12.0 \\
15.0 \\
17.0 \\
2.0 \\
1.9\end{array}$ & $\begin{array}{l}15.0 \\
14.0 \\
14.0 \\
15.0 \\
14.0 \\
14.0 \\
14.0 \\
15.6 \\
13.0 \\
14.0 \\
14.0 \\
16.0 \\
19.0 \\
15.6 \\
17.6 \\
15.0 \\
23.5 \\
17.0 \\
18.0 \\
20.0 \\
20.5 \\
17.5 \\
20.0 \\
23.5 \\
24.0 \\
13.0 \\
16.0\end{array}$ \\
\hline
\end{tabular}

1 Specimen intermediate between Leconteites and Brewericeras. 2 Slightly crushed.

\section{REFERENCES}

Anderson, F. M., 1902, Cretaceous deposits of the Pacific Coast: California Acad. Sci. Proc., 3d ser., v. 2, no. 1, 1-54 p., 11 pls.

1938, Lower Cretaceous deposits in Cailfornia and Oregon: Geol. Soc. America Spec. Paper 16, 339 p. 84 pls., 3 figs.

Arkell, W. J., Kummel, Bernhard, and Wright, C. W., 1957, Mesozoic Ammonoidea, in Mollusca 4, Pt. L of Moore, R. C., ed., Treatise on invertebrate paleontology: New York, Geol. Soc. America and Kansas Univ. Press [Lawrence], p. L80-L471.

Casey, Raymond, 1954, New genera and subgenera of Lower Cretaceous ammonites: Washington Acad. Sci. Jour., v. 44, no. 4, p. 106-115, 1 pl.

—_ 1961, The Ammonoidea of the Lower Greensand: Palaeontographical Soc., Monograph, pt. 3, p. 119-216, pls. 26-35.

Crickmay, C. H., 1927, On Beudanticeras breweri and Coloboceras stantoni: Am. Jour. Sci., 5th ser., v. 13, no. 78, p. 503-516, 10 figs.

Gabb, W. M., 1864, Description of the Cretaceous fossils: California Geol. Survey, Paleontology, v. 1, sec. 4, p. 57-217, pls. 9-32.

1869, Cretaceous and Tertiary fossils, in Paleontology of California: California Geol. Survey, Paleontology, v. 2, sec. 2 , p. 127-254.

Haas, Otto, 1946, Intraspecific variation in, and ontogeny of, Prionotropis woollgari and Prionocyclus wyomingensis: Am. Mus. Nat. History Bull., v. 86, art. 4, p. 141-224, pls. 11-24.

Hall, E. B., and Ambrose, A. W., 1916, Descriptions of new species from the Cretaceous and Tertiary of the Tesla, Pleasanton, San Jose, and Mt. Hamilton quadrangles, California: Nautilus, v. 30 , no. 6 , p. $68-71$; v. 30 , no. 7 , p. 77-82. 
Imlay, R. W., 1960, Early Cretaceous (Albian) ammonites from the Chitina Valley and Talkeetna Mountains, Alaska: U.S. Geol. Survey Prof. Paper 354-D, p. 87-114, pls. 11-19. 1961, Characteristic Lower Cretaceous megafossils from northern Alaska: U.S. Geol. Survey Prof. Paper 335, 74 p., 24 pls., 1 fig.

Jones, D. L., and Berg, H. C., 1964, Cretaceous stratigraphy of the McCarthy A-4 quadrangle, southern Alaska: U.S. Geol. Survey Bull. 1180-A, p. A1-A18.

McKnight, B. K., 1964, Stratigraphic study of Cretaceous rocks near Mitchell, Oregon [abs.]: Geol. Soc. America Spec. Paper 82, p. 264.

Murphy, M. A., 1956, Lower Cretaceous stratigraphic units of northern California: Am. Assoc. Petroleum Geologists Bull., v. 40, no. 9, p. 2098-2119, 6 text-figs.

Murphy, M. A., Peterson, G. L., and Rodda, P. U., 1964, Revision of Cretaceous lithostratigraphic nomenclature, northwest Sacramento Valley, California: Am. Assoc. Petroleum Geologist, v. 48, no. 4, p. 496-502.

Murphy, M. A., and Rodda, P. U., 1960, Mollusca of the Cretaceous Bald Hills Formation of California: Jour. Paleontology, v. 34 , no. 5, p. 835-858, pls. 101-107, 2 text-figs.
Popenoe, W. P., Imlay, R. W., and Murphy, M. A., 1960, Correlation of the Cretaceous formations of the Pacific Coast (United States and northwestern Mexico): Geol. Soc. America Bull., v. 71, no. 10, p. 1491-1540, 1 pl., 5 figs.

Reeside, J. B., Jr., and Cobban, W. A., 1960, Studies of the Mowry Shale (Cretaceous) and contemporary formations in the United States and Canada: U.S. Geol. Survey Prof. Paper 355, 126 p., 58 pls., 30 figs., 10 tables.

Silberling, N. J., 1959, Pre-Tertiary stratigraphy and Upper Triassic paleontology of the Union district, Shoshone Mountains, Nevada: U.S. Geol. Survey Prof. Paper 322, 67 p., 11 pls., 3 figs.

Whiteaves, J. F., 1876, On some invertebrates from the coalbearing rocks of the Queen Charlotte Islands, in Mesozoic fossils: Canada Geol. Survey, v. 1, pt. 1, p. 1-92, 10 pls. 1893, Descriptions of two new species of ammonites from the Cretaceous rocks of the Queen Charlotte Islands: Canadian Record Sci., v. 5, no. 8, p. 441-446, pl. 7.

Wiedey, L. W., 1929, Some previously unpublished figures of type mollusks from California: Nautilus, v. 43, no. 1, p. 21-26, 3 pls. 


\section{INDEX}

[Italic numbers indicate descriptions]

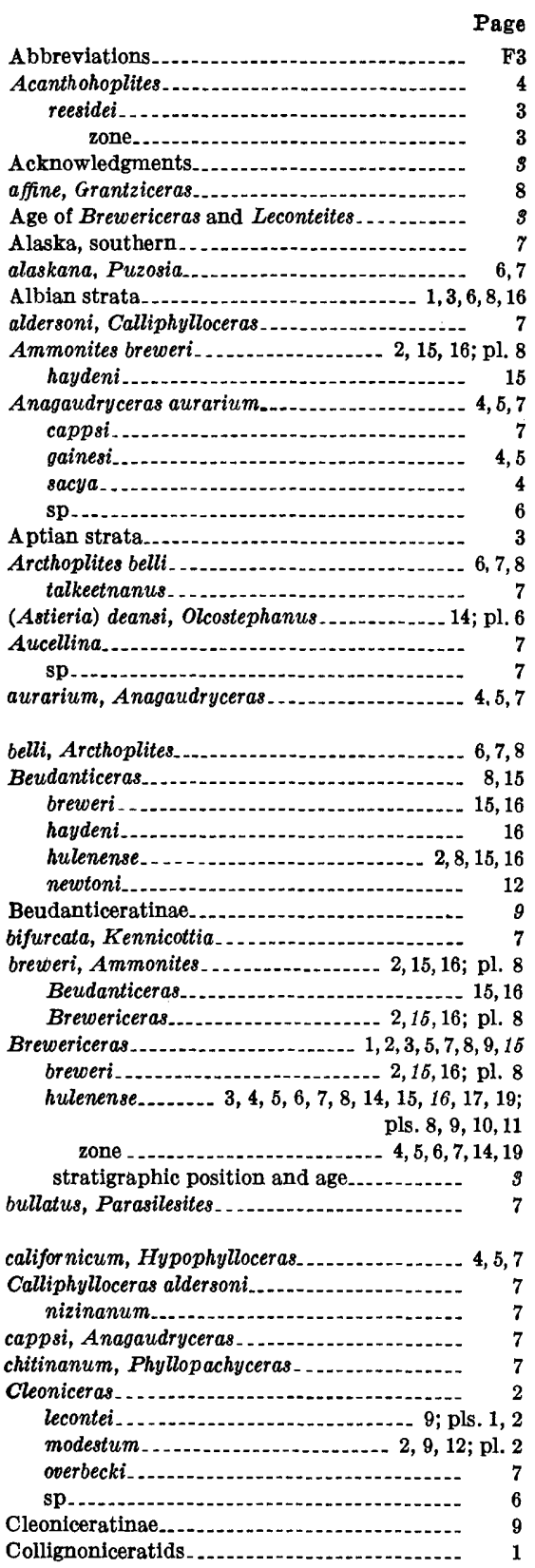

deansi, Leconteites_.... $2,3,6,7,8,9,10,13,14,19 ;$ pl. 6 Olcostephanus (Astieria)

Desmoceras haydeni........................ 16

lecontei_............................... 1, 2 ;

merriami............ 5

sp........

Desmoceratidae.

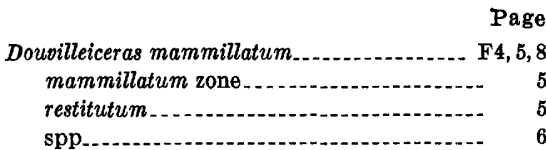

Evolutionary sequence of Leconteites and Brewericeras...........................

Freboldiceras.

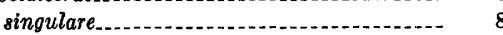

gainesi, Anagaudryceras.

Gener:c description, revised

Glabrum, Grantziceras

rantziceras affine glabrum.

sp...

haydeni, Ammonites. Beudanticeras. Desmoceras.

Hoplitidae.

hulenense, Beudanticeras . ................. 2, 15, 16 Brewericeras. $7,8,14,15,16,17,19 ;$ pls. $8,9,10,11$

Hulenites reesidei...

Hypacanthoplites $\mathrm{sp}$

Hypophylloceras californicum........ 4, 5, 7

irregularis, Parasilesites..................... 7

Jauberticeras michelianum

Kennicottia bifurcata................. 7

laeve, Ptychoceras

Desmoceras.......................... 1, 2, 9 ; pl. 2

Leconteites...................... 3,4, 5, 6, 8, 9, 10 ,

$12,13,14,16,17,19 ;$ pls. $1,2,3,4,5,11$

whiteavesi, Leconteites............ 7, 13; pls. 6, 7

Leconteites................ 1, 2, 3

$5,6,7,8,9,13,14,15,17,19 ;$ pls. 1,2

deansi_......... 2, 3, 6, 7, 8, 9, 10,13,14,19; pl. 6

lecontei.................. $3,4,5,6,7,8,9,10$,

$12,13,14,16,17,19 ;$ pls. $1,2,3,4,5,11$

whiteavesi

zone.

modestus.................. 3,14

sacramenticus_..................... 9, 14; pl. 2

stratigraphic position and age............. 3

Leymeriella tardefurcata zone.

mammillatum, Douvilleiceras.................. 4, 5,8

Material studied.

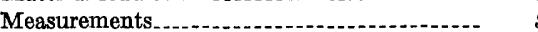

merriami, Desmoceras............. 5

michelianum, Jauberticeras.

modestum, Cleoniceras.

modestus, Leconteites ....................... 2,14

Moffitites robustus.............................. 7;14

mulleri, Puzosigella

2,$9 ;$ pl. 2

Sonneratia.

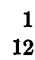

Neogastroplites

newtoni, Beudanticeras.

nizinanum, Calliphylloceras $\begin{aligned} \text { Page } & \text { F1 }\end{aligned}$

Olcostephanus (Astieria) deansi............ 14; pl. 6

Ono area

Oregon, central

overbecki, Cleoniceras...................... 7

Oxytropidoceras packardi.......... 5

Pachydiscus sacramenticus........... 1, 2, 9, 14; pl. 2

packardi, Oxytropidoceras.................... 5

Parahoplites stantoni.............- 5

Parasilesites bullatus

irregularis. . . .

sp.

perrinsmithi, Sonneratia........... 2, 9, 12; pl. 1

Phyllopachyceras chitinanum................ 7 shastalense............................... 7

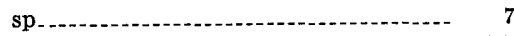

Ptychoceras laeve

Puzosia alaskana ........................ 6,7 subquadrata

puzosiaformis, Silesites...................... 4

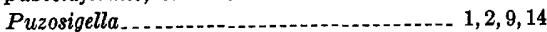

mulleri

rogersi.

sacramentica........... 14

sp. .

Queen Charlotte Islands_................... 6,13

reesidei, Acanthohoplites.................... 3

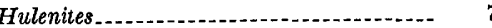

restitutum, Douvilleiceras.................... 5

Revised generic description................... 9

robustus, Moffitites....... 7,14

rogersi, Puzosigella....................... 2, 9,14 Sonneratia....................... 2, 9; pls. 1, 3

sacramentica, Puzosigella.................... 14 Sonneratia $\ldots . . .14 ; \mathrm{pl} .2$ sacramenticus, Leconteites................ 9, 14; pl. 2

Pachydiscus .................. 1, 2, 9, 14; pI. 2 sacya, Anagaudryceras.

shastalense, Phyllopachyceras...........

Silesites puzosiaformis......................... 4

singulare, Freboldiceras............-. 8

Sonneratia.

mulleri._........................... 2, 9 ; pl. 2

perrinsmithi . .................. 2, 9, 12; pl. 1

rogersi............... 2, 9; pls. 1, 3

sacramentica........................... 14; pl.

taffi.

stantoni, Parahoplites

Stratigraphïc position, Brewericeras.........-

Leconteites...............................

subquadrata, Puzosia

Systematic descriptions . .................... $g$

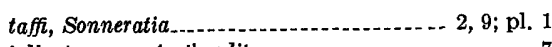
talkeetnanus, Arcthoplites.................. 7 tardefurcata, Leymeriella..................... 4

Tetragonites sp........ 4, 5,6,7

Tropites.

Valdedorsella whiteavesi_................... 7

whiteavesi, Leconteites lecontei _........ 7, 18; pls. 6, 7

Valdedorsella........................... 7 


\section{PLATES 1-11}




\section{PLATE 1}

[All figures natural size]

Figures 1-22. Leconteites lecontei (Anderson) s. s. (p. F9).

1-3, 17-19. Sonneratia rogersi Hall and Ambrose.

1-3. Plastohypotype, CAS 8866; figured by Anderson (1938, pl. 20, fig. 6).

17-19. Plastohypotype, CAS unnumbered; figured by Anderson (1938, pl. 20, fig. 7).

6-8, 22. Sonneratia perrinsmithi Anderson.

6-8. Plastoparatype, CAS 8884; figured by Anderson (1938, pl. 51, fig. 5).

22. Plastoholotype, CAS 8882; figured by Anderson (1938, pl. 31, fig. 5).

9-11, 14, 15, 20. Sonneratia taffi Anderson.

9-11. Plastoparatype, CAS 8858; figured by Anderson (1938, pl. 49, fig. 5).

14, 15, 20. Plastoholotype, CAS 8857; figured by Anderson (1938, pl. 49, fig. 4).

13, 16, 21. Cleoniceras lecontei (Anderson).

Plastoplesiotype, CAS 8868; figured by Anderson (1938, pl. 47, fig. 4).

4, 5, 12. "Sonneratia perrinsmithi" Anderson.

Plastoparatype, CAS 8883; figured by Anderson (1938, pl. 51, fig. 6). This specimen does not belong to $S$. perrinsmithi nor to Leconteites. 
GEOLOGICAL SURVEY
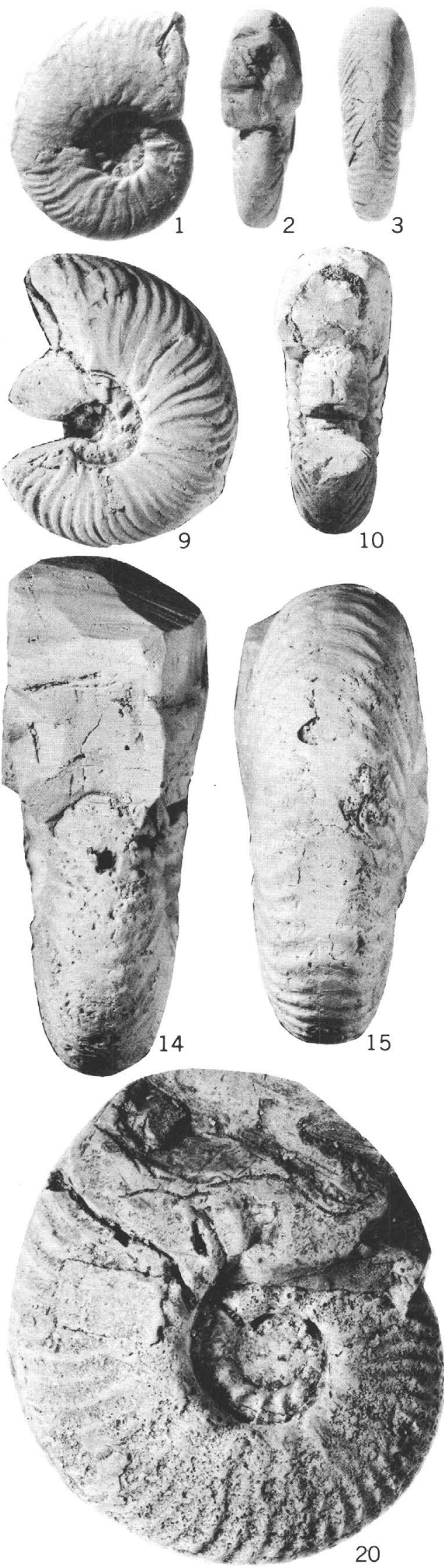
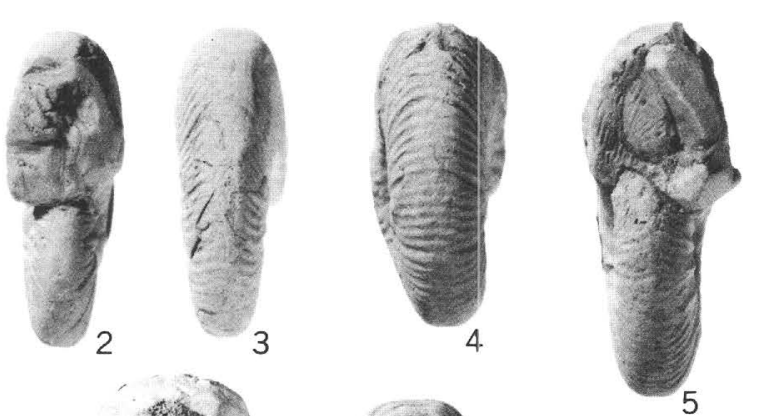

PROFESSIONAL PAPER 503-F PLATE 1
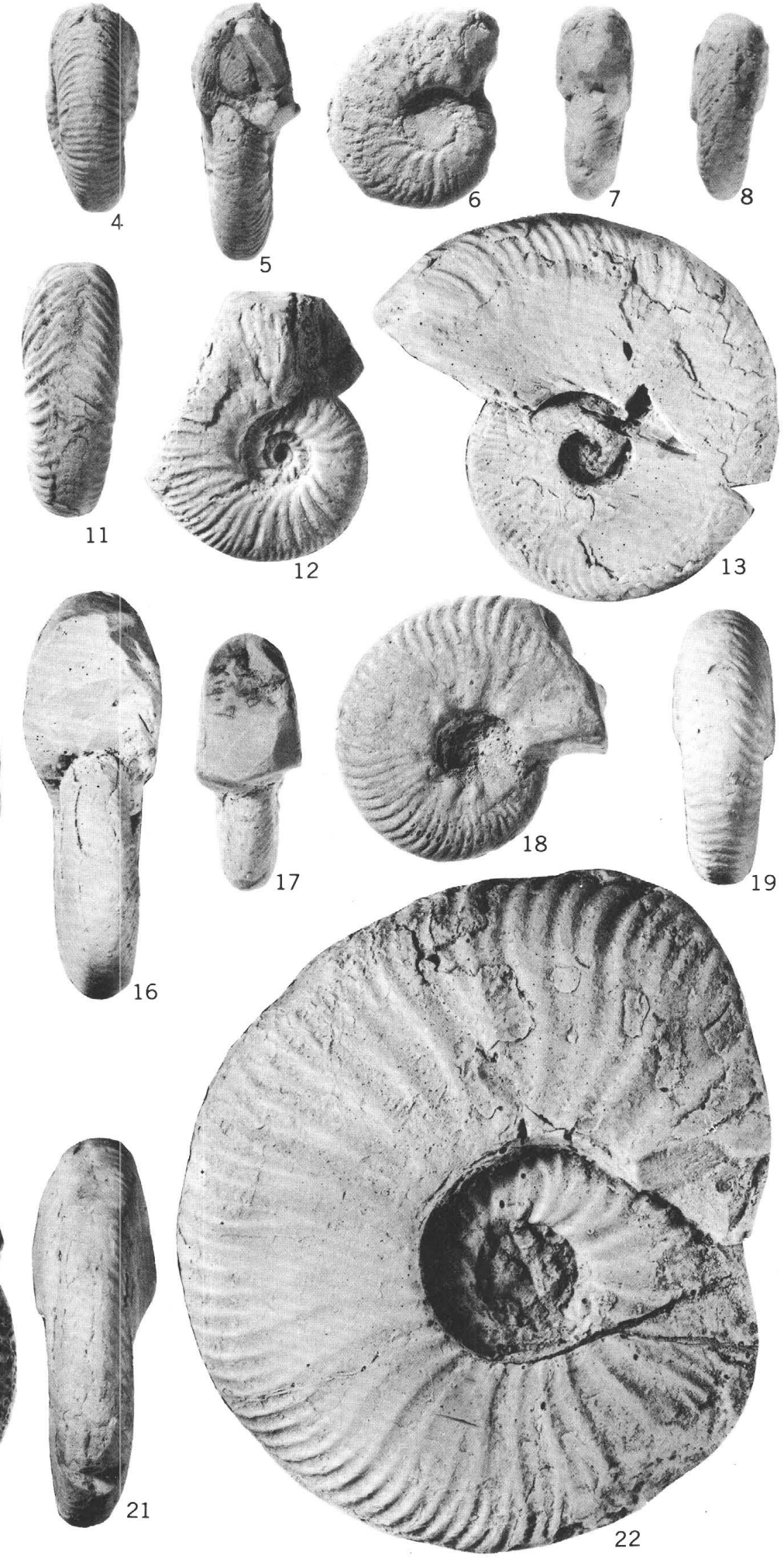

LECONTEITES 


\section{PLATE 2}

[All figures natural size]

Figures 1-8, 10-14, 17, 21. Leconteites lecontei (Anderson) s. s. (p. F9).

$1-3,7,8,13$. Cleoniceras modestum Anderson.

1-3. Plastoparatype, CAS 8872; figured by Anderson (1938, pl. 50, fig. 4).

7, 8, 13. Plastoparatype, CAS 8871; figured by Anderson (1938, pl. 50, fig. 3). The holotype (CAS 8870) of C. modestum does not belong to Leconteites.

4-6, 12, 14, 21. Cleoniceras lecontei (Anderson).

4-6. Plastohypotype, CAS 8869; figured by Anderson (1938, pl. 47, fig. 5).

12, 14, 21. Plastoholotype, UC 12093; figured by Anderson (1902, pl. 3, figs. 94, 95) as Desmoceras lecontei.

10, 11, 17. Sonneratia mulleri Anderson.

Plastoholotype, CAS 8864; figured by Anderson (1938, pl. 51, fig. 4; pl. 54, fig. 4).

9, 15, 16, 18-20. Leconteites sacramenticus (Anderson) (p. F14).

9, 15, 16. Sonneratia sacramentica (Anderson).

Plastohypotype, CAS 8859; figured by Anderson (1938, pl. 49, fig. 3).

18-20. Plastoholotype, UC 12100, figured by Anderson (1902, pl. 6, figs. 133, 134) as Pachydiscus sacramenticus. 
GEOLOGICAL SURVEY
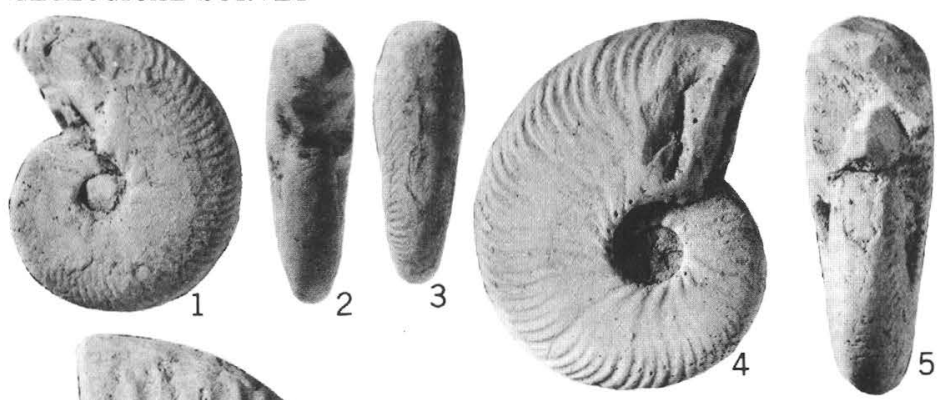

PROFESSIONAL PAPER 503-F PLATE 2
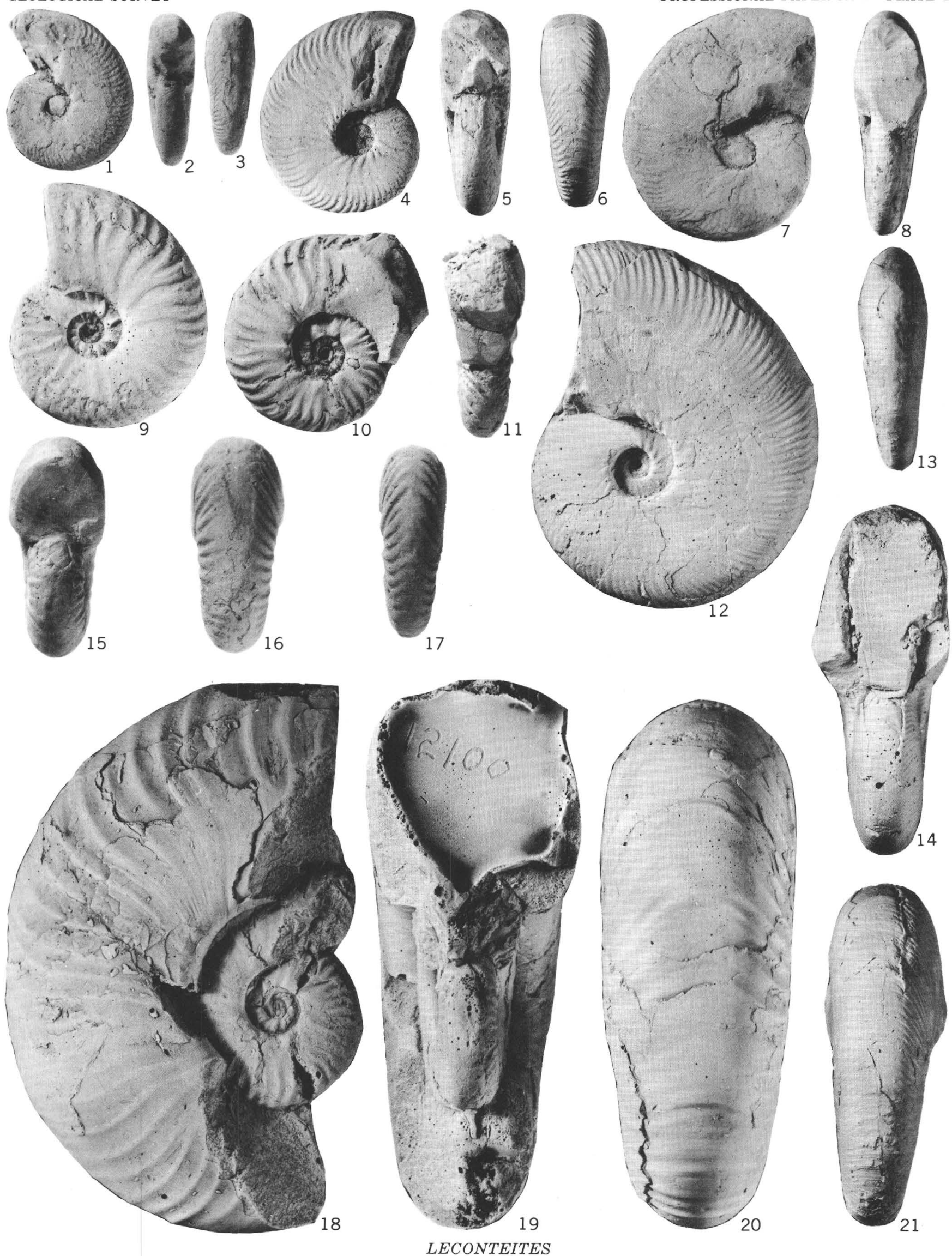


\section{PLATE 3}

[All figures natural size]

FIGURES 1-45. Leconteites lecontei (Anderson) s. s. (p. F9).

All specimens from central Oregon, except figures 31-33, which are from central California. Specimens are arranged with finely ribbed forms on left side of plate and progressively more coarsely ribbed forms to the right.

1-3. Hypotype, USNM 121486 from USGS Mesozoic loc. M2284.

4-6. Hypotype, USNM 121487 from USGS Mesozoic loc. M2284.

7-9. Hypotype, USNM 121488 from USGS Mesozoic loc. 15801.

10-12. Hypotype, USNM 121489 from UO loc. 4082.

13-15. Hypotype, USNM 121490 from USGS Mesozoic loc. 26262.

16-18. Hypotype, USNM 121491 from USGS Mesozoic loc. M2284.

19-21. Hypotype, USNM 121492 from USGS Mesozoic loc. M2284.

22-24. Hypotype, USNM 121493 from USGS Mesozoic loc. M2284.

25-27. Hypotype, USNM 121494 from UO loc. 4082.

28-30. Hypotype, USNM 121495 from UO loc. 4082.

31-33. Sonneratia rogersi Hall and Ambrose.

Holotype, Stanford Univ. Paleont. type colln. 511; figured by Wiedey (1929, pl. 2, fig. 2).

34-36. Hypotype, USNM 121496 from USGS Mesozoic loc. 26262.

37-38. Hypotype, USNM 121497 from USGS Mesozoic loc. M2284.

39-41. Hypotype, USNM 121498 from USGis Mesozoic loc. 26262.

42-44. Hypotype, USNM 121499 from USGS Mesozoic loc. 15801.

45. Hypotype, USNM 121500 from USGS Mesozoic loc. 26262. 


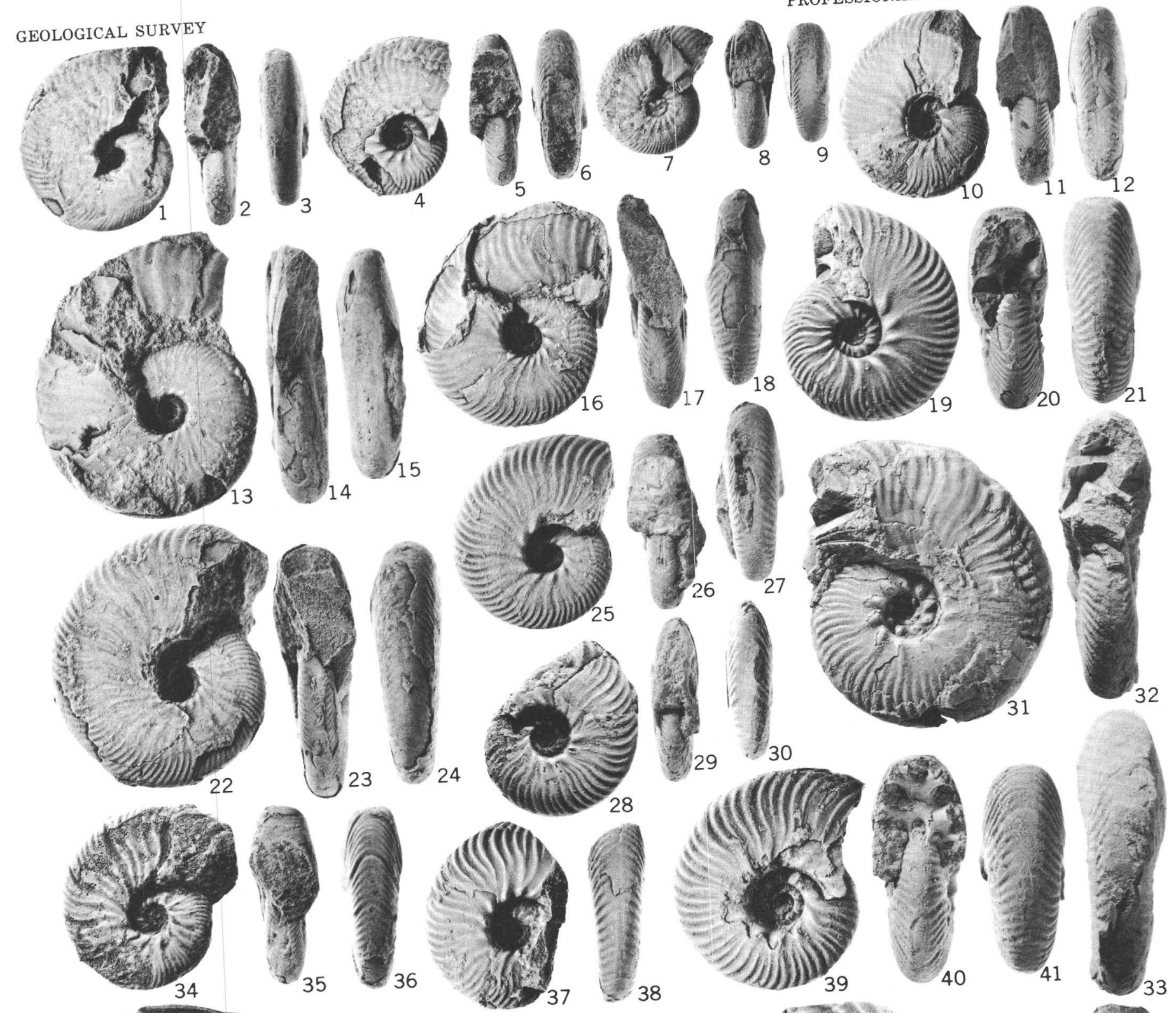

PROFESSIONAL PAPER 503-F PLATE 3 
PLATE 4

[All figures natural size except as indicated]

Figures 1-36. Leconteites lecontei (Anderson) s. s. (p. F9).

All specimens from central Oregon showing coarsely ribbed variants.

1-6. Hypotype, USNM 121501 from USGS Mesozoic loc. M2284 (figs. 4-6 are $\times 2$ ).

7-8. Hypotype, USNM 121502 from USGS Mesozoic loc. 26262.

9-11. Hypotype, USNM 121503 from UO loc. 465.

12-14. Hypotype, USNM 121504 from UO loc. 4082.

15-17. Hypotype, USNM 121505 from UO loc. 4082.

18-20. Hypotype, USNM 121506 from USGS Mesozoic loc. 26262.

21-23. Hypotype, USNM 121507 from USGS Mesozoic loc. 26262.

24-26. Hypotype, USNM 121508 from USGS Mesozoic loc. M2284.

27-29. Hypotype, USNM 121509 from USGS Mesozoic loc. 26378.

30-32. Hypotype, USNM 121510 from USGS Mesozoic loc. 26262.

33-35. Hypotype, USNM 121512 from USGS Mesozoic loc. 26262.

36. Hypotype, USNM 121513 from USGS Mesozoic loc. M2284. 
GEOLOGICAL SURVEY
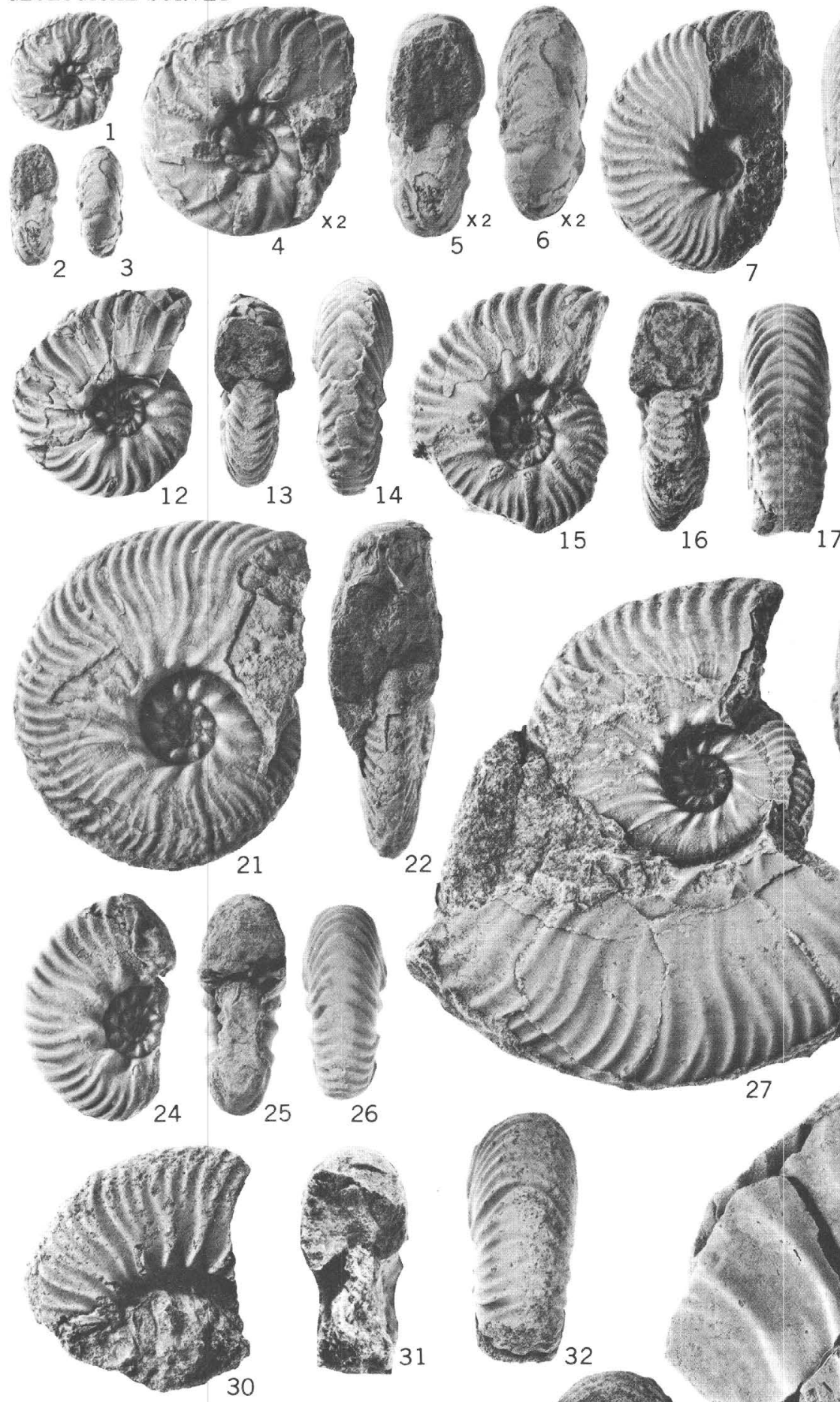

$v^{4} y^{2}-y^{2}-1 y^{2}$

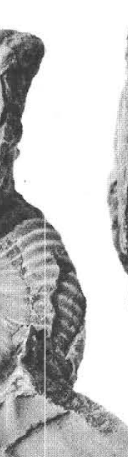

and
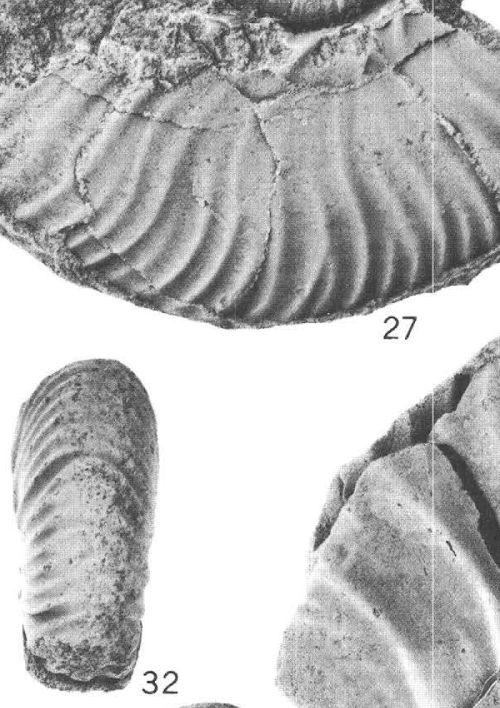
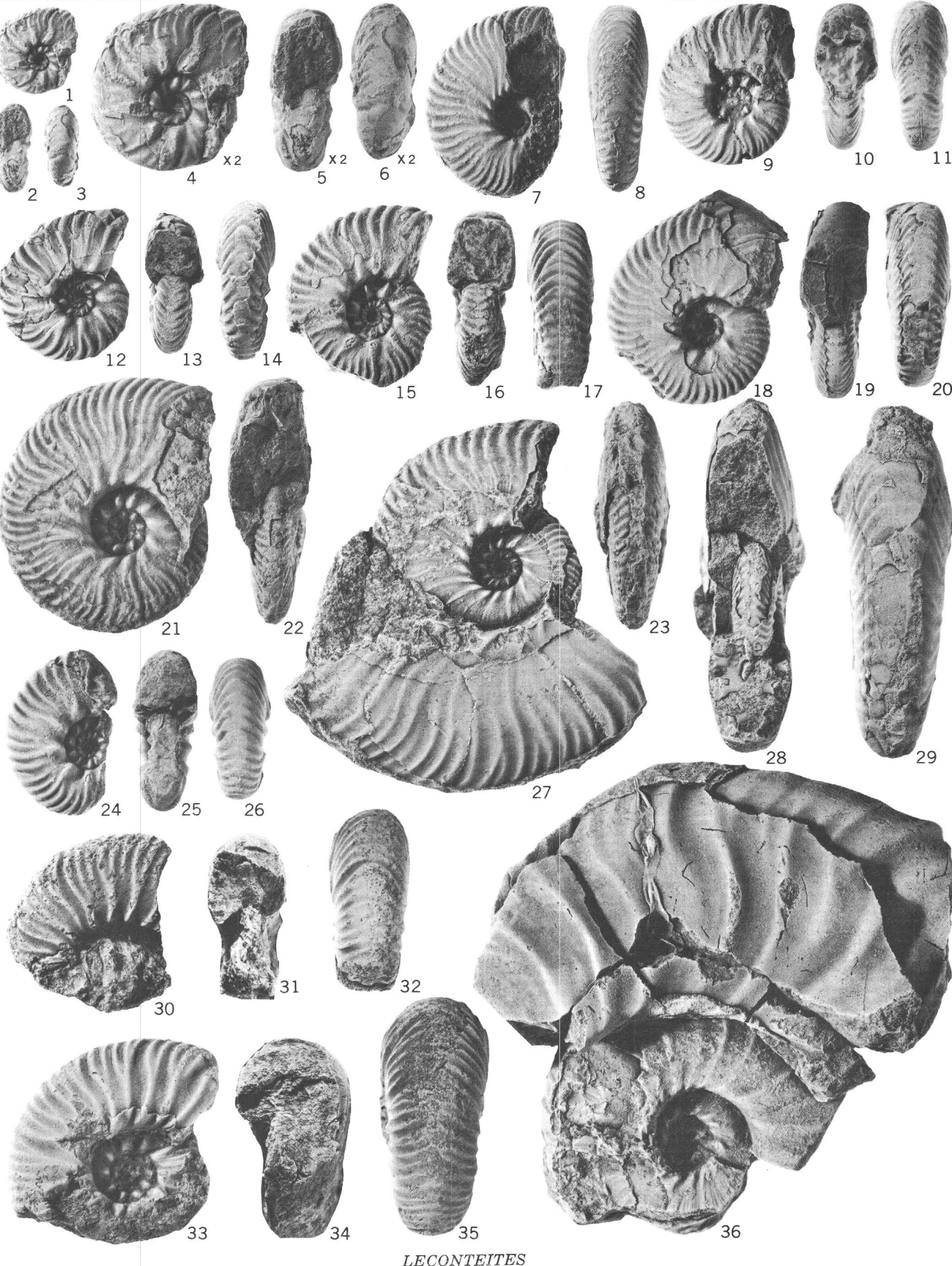


\section{PLATE 5}

[All figures natural size]

Figures 1-31. Leconteites lecontei (Anderson) s. s. (p. F9).

All specimens are from the Leconteites lecontei zone on Huling Creek and ase figured to demonstrate that a wide range of morphologic variation exists for this species throughout the zone. Specimens shown on figs. 1-6, $14-16,23,27$, and 28 are from near the top of the zone; those shown on figs. 10-11, 20-22, 24-26, are from the middle of the zone (see also pl. 11, figs. 4-6); specimens shown on figs. 7-9, 12, 13, 17-19, and 29-31 are from the lower part of the zone.

1-3. USNM hypotype 121514 from UCR loc. 164.

4-6. USNM hypotype 121515 from UCR loc. 164.

7-9. USNM hypotype 121516 from UCR loc. 347.

10-11. USNM hypotype 121517 from UCR loc. 89.

12-13. USNM hypotype 121518 from UCR loc. 347.

14-16. USNM hypotype 121519 from UCR loc. 463.

17-19. USNM hypotype 121520 from UCR loc. 359.

20-22. USNM hypotype 121521 from UCR loc. 89.

$23,27,28$. USNM hypotype 121522 from UCR loc. 460 .

24-26. USNM hypotype 121523 from UCR loc. 89.

29-31. USNM hypotype 121524 from UCR loc. 435. 
GEOLOGICAL SURVEY

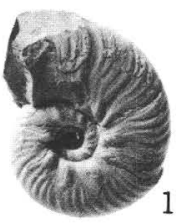

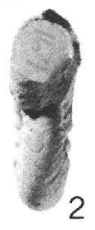
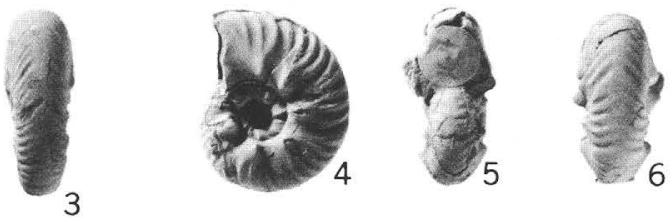

PROFESSIONAL PAPER 503-F PLATE 5
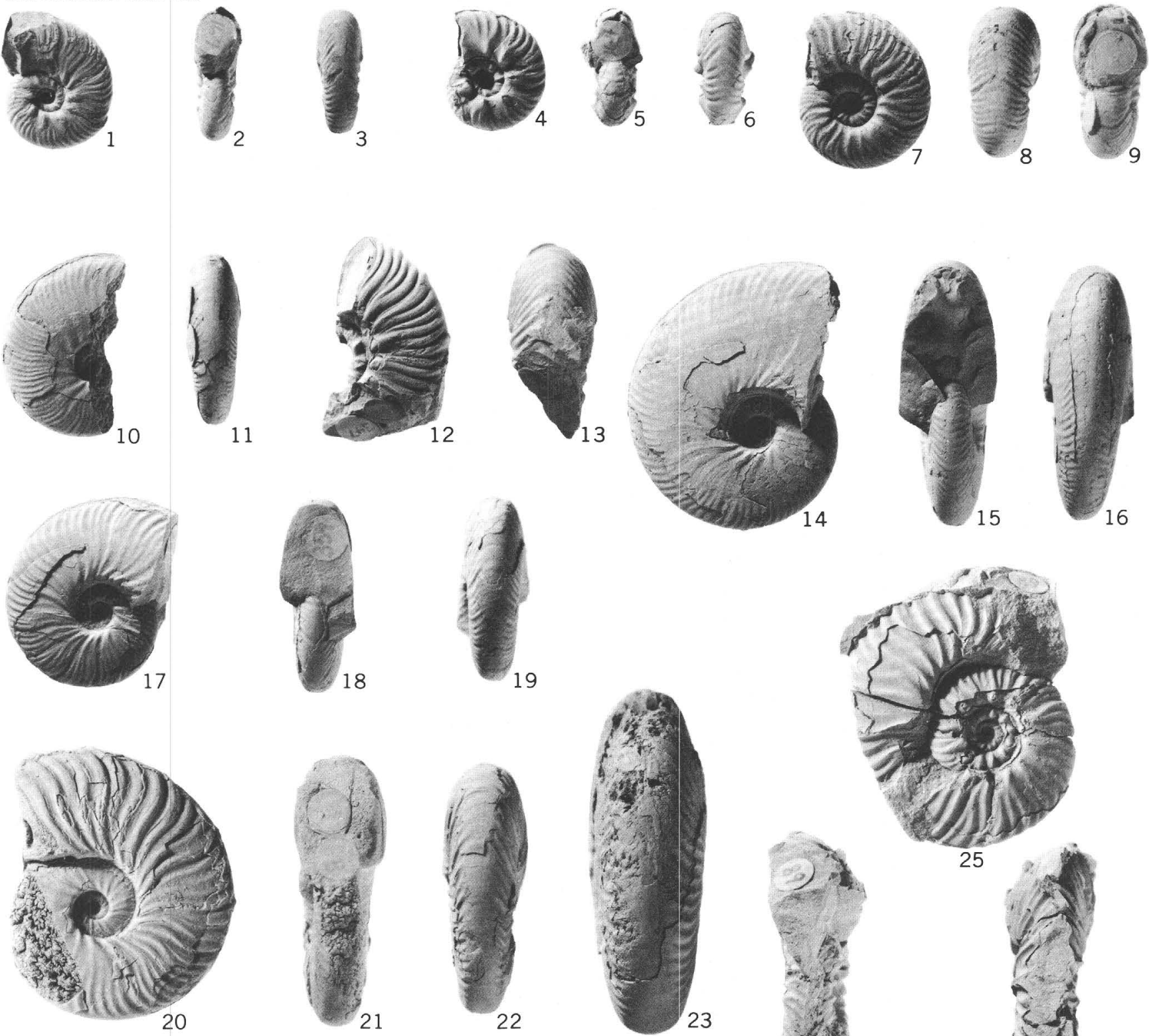

20
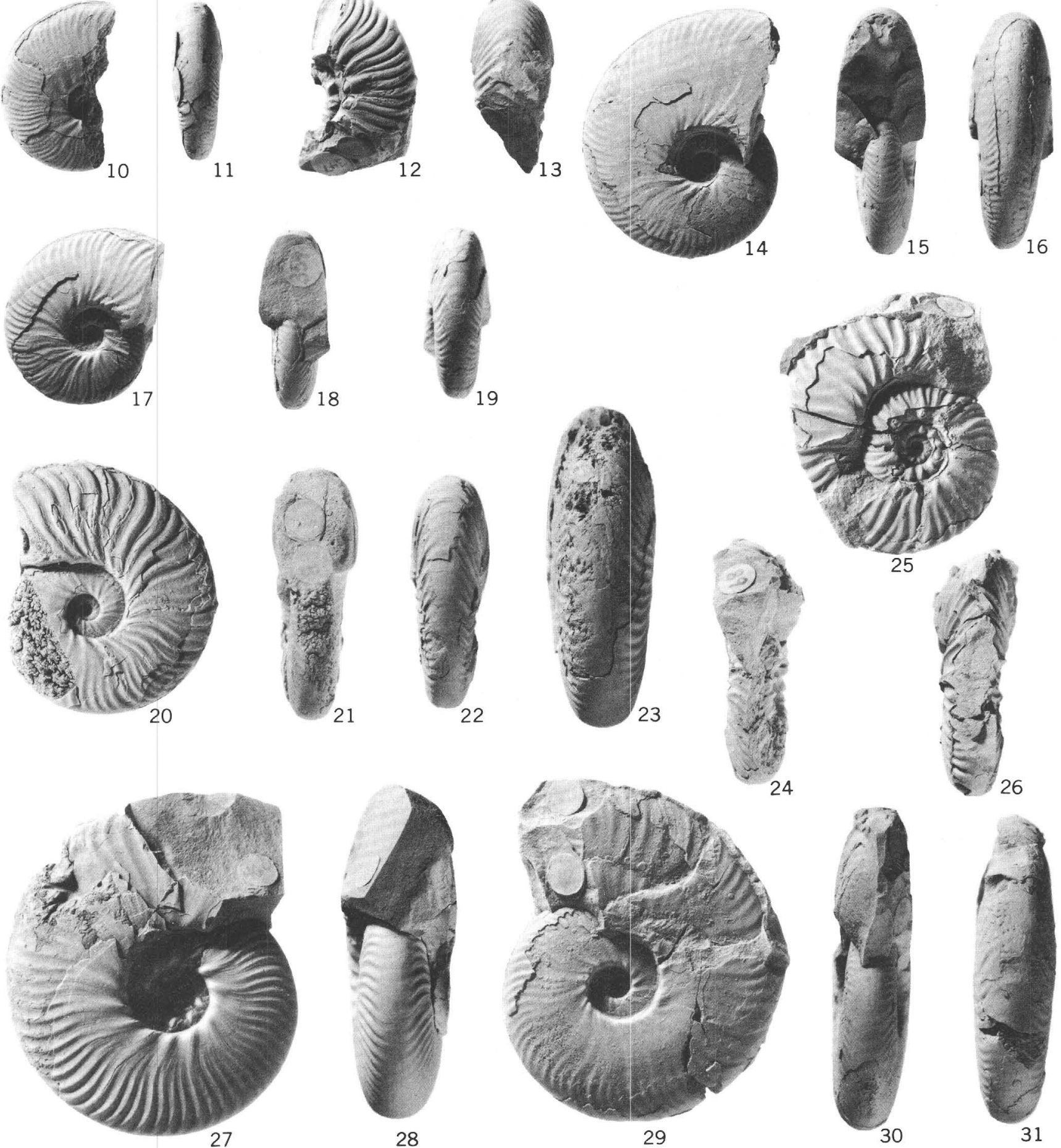

28

29
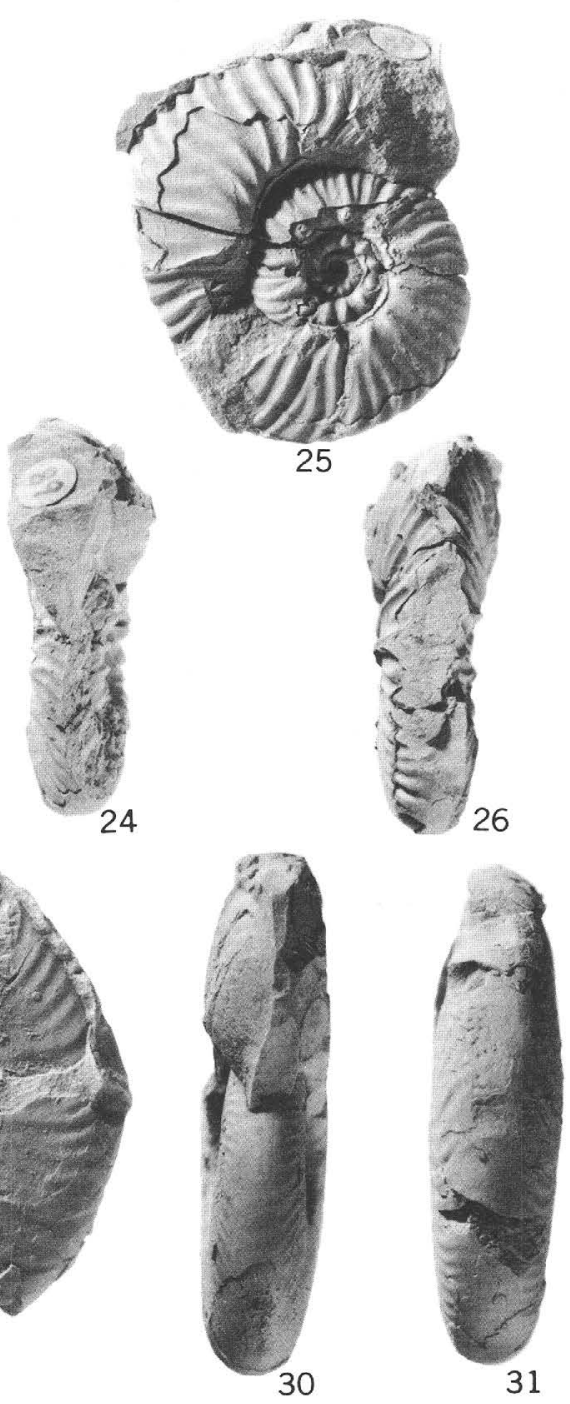

LECONTEITES 


\section{PLATE 6}

\section{[All figures natural size]}

Figure 1-3, 4-9, 12-14. Leconteites lecontei whiteavesi, Jones, Murphy, and Packard, n. subsp. (p. F13). GSC loc. 48615. Beresford Bay, Queen Charlotte Islands.

1-3. Paratype, GSC 19098.

4-5. Paratype, GSC 19099.

6-7. Paratype, GSC 19100.

8-9. Paratype, GSC 19101.

12-14. Paratype, GSC $19102(\times 4 / 5)$.

10, 11, 15, 16. Leconteites deansi (Whiteaves) (p. F13).

10, 15. Copy of Whiteaves, (1893, pl. 7, figs. 1, 1a) original figure of Olcostephanus (Astieria) deansii.

11, 16. Hypotype, USNM 130164b, from USGS Mesozoic loc. 9972, Chitina Valley, southern Alaska, originally figured by Imlay (1960, pl. 19, figs. 12-14). 
GEOLOGICAL SURVEY
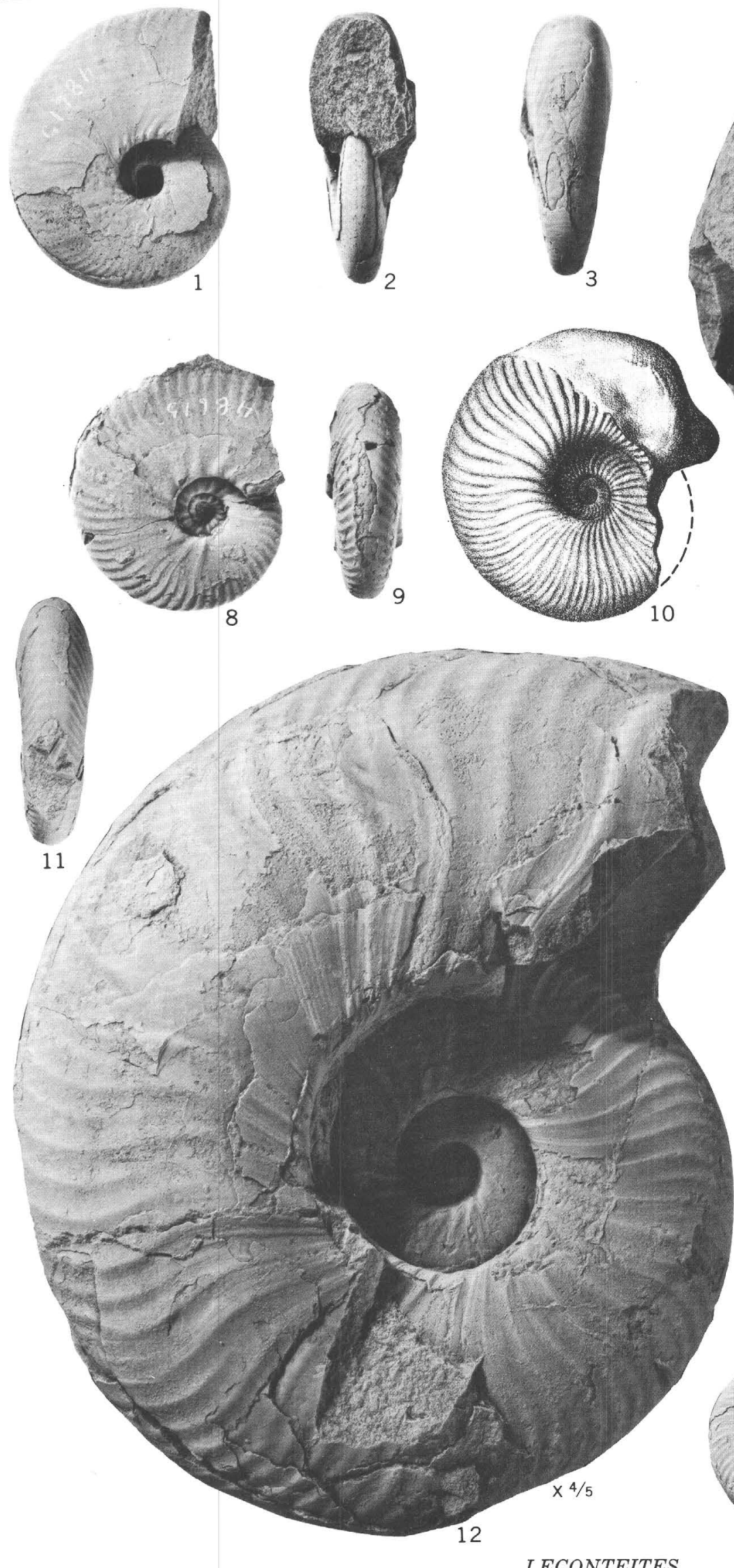

PROFESSIONAL PAPER 503-F PLATE 6
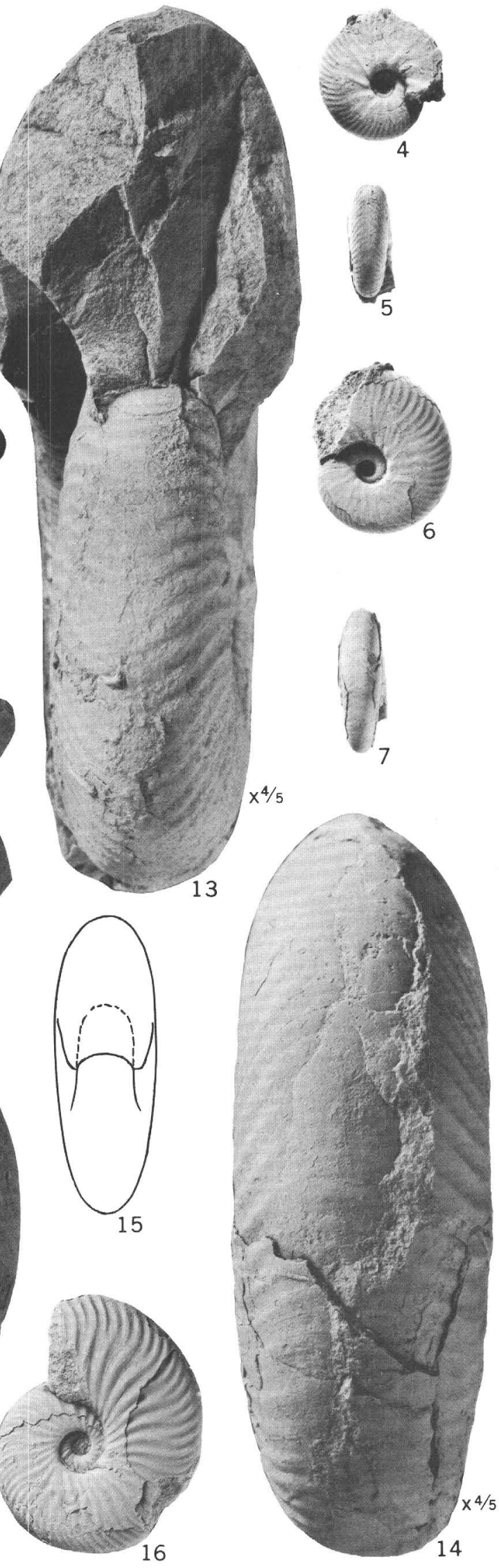


\section{PLATE 7}

[All figures $\times \%$ ]

Figures 1-3. Leconteites lecontei whiteavesi Jones, Murphy, and Packard, n. subsp., (p. F13). Holotype, GSC 19097, from GSC loc. 48615, Beresford Bay, Queen Charlotte Islands. 


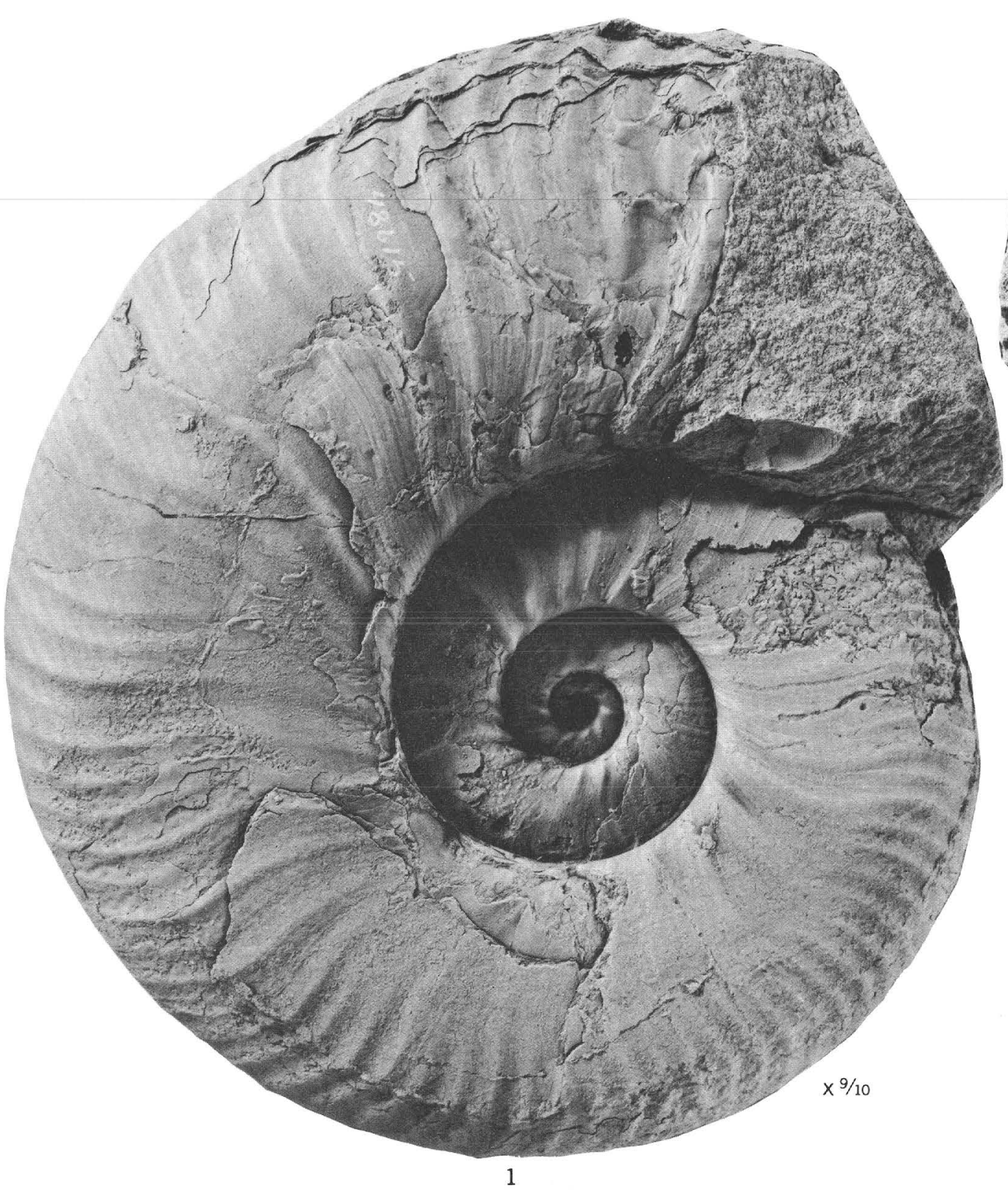

1
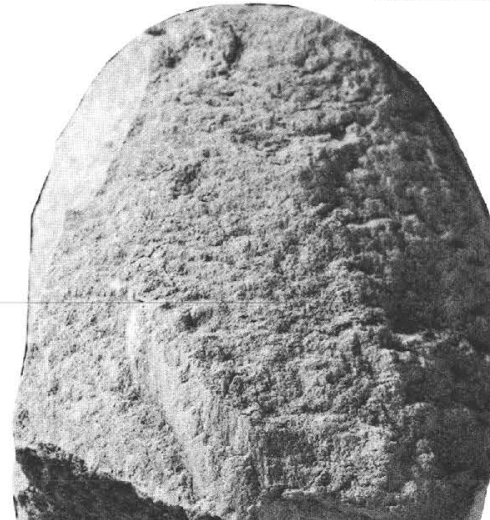

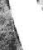

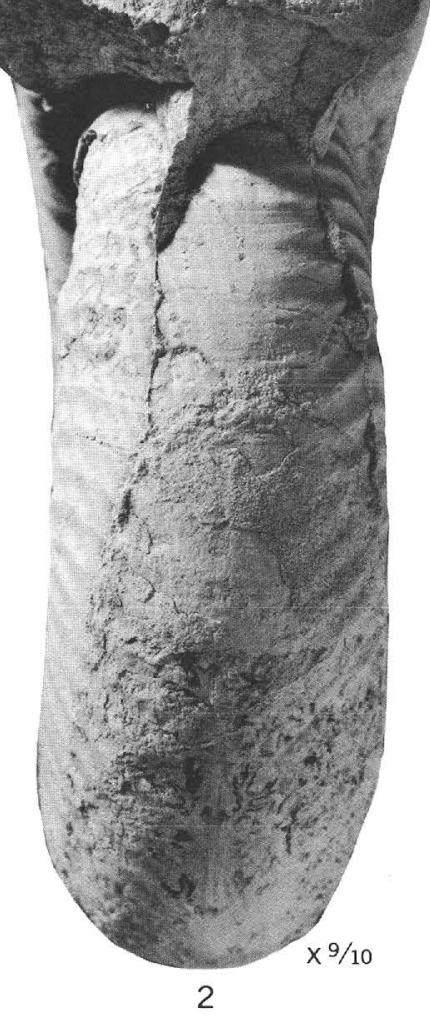

2

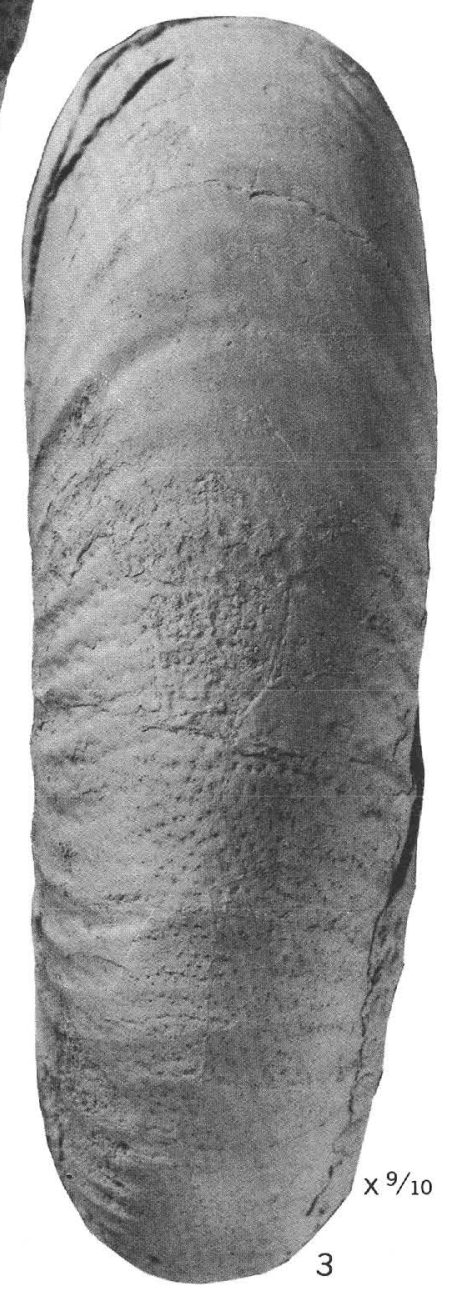




\section{PLATE 8}

[All figures natural size]

Figures 1, 2, 4. Brewericeras hulenense (Anderson) (p. F16).

Hypotype, ANSP 4798. Specimen figured by Gabb (1869, pl. 20, fig. 5) as $A$. breweri.

3, 5. Brewericeras breweri (Gabb) (p. F15).

Holotype, UC 12098, figured by Gabb (1864, pl. 10, fig. 7). 

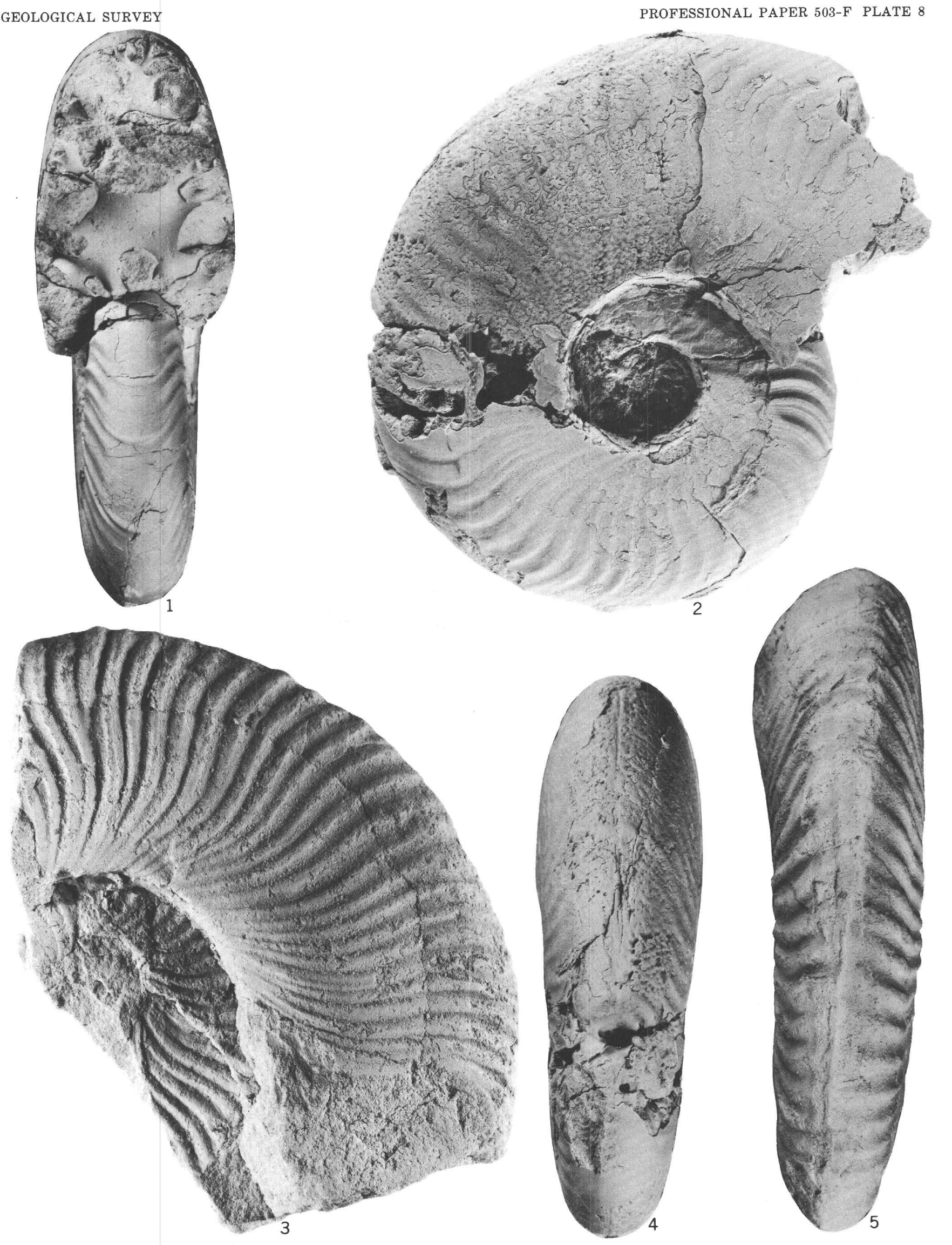


\section{PLATE 9}

[All figures natural size]

Figures 1-9. Brewericeras hulenense (Anderson) (p. F16).

From northern California.

1, 5, 6, 8. Hypotype, USNM 121526, from UCR loc. 70.

2-4. Hypotype, USNM 121527, from UCR loc. 34.

7-9. Hypotype, USNM 121528, from UCR loc. 98. 
GEOLOGICAL SURVEY

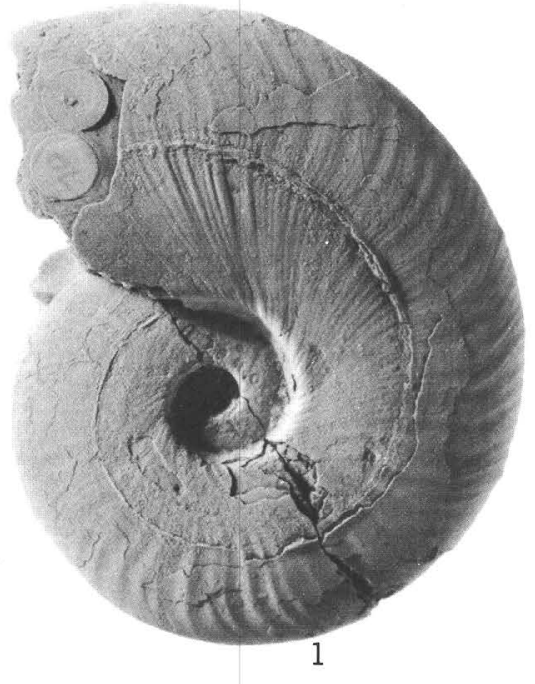

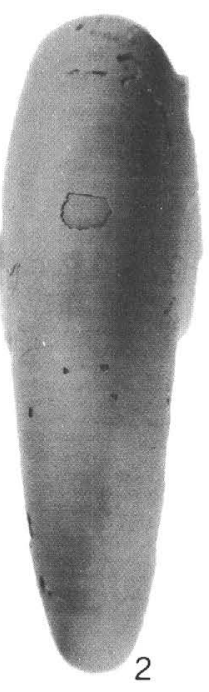

PROFESSIONAL PAPER 503-F PLATE 9

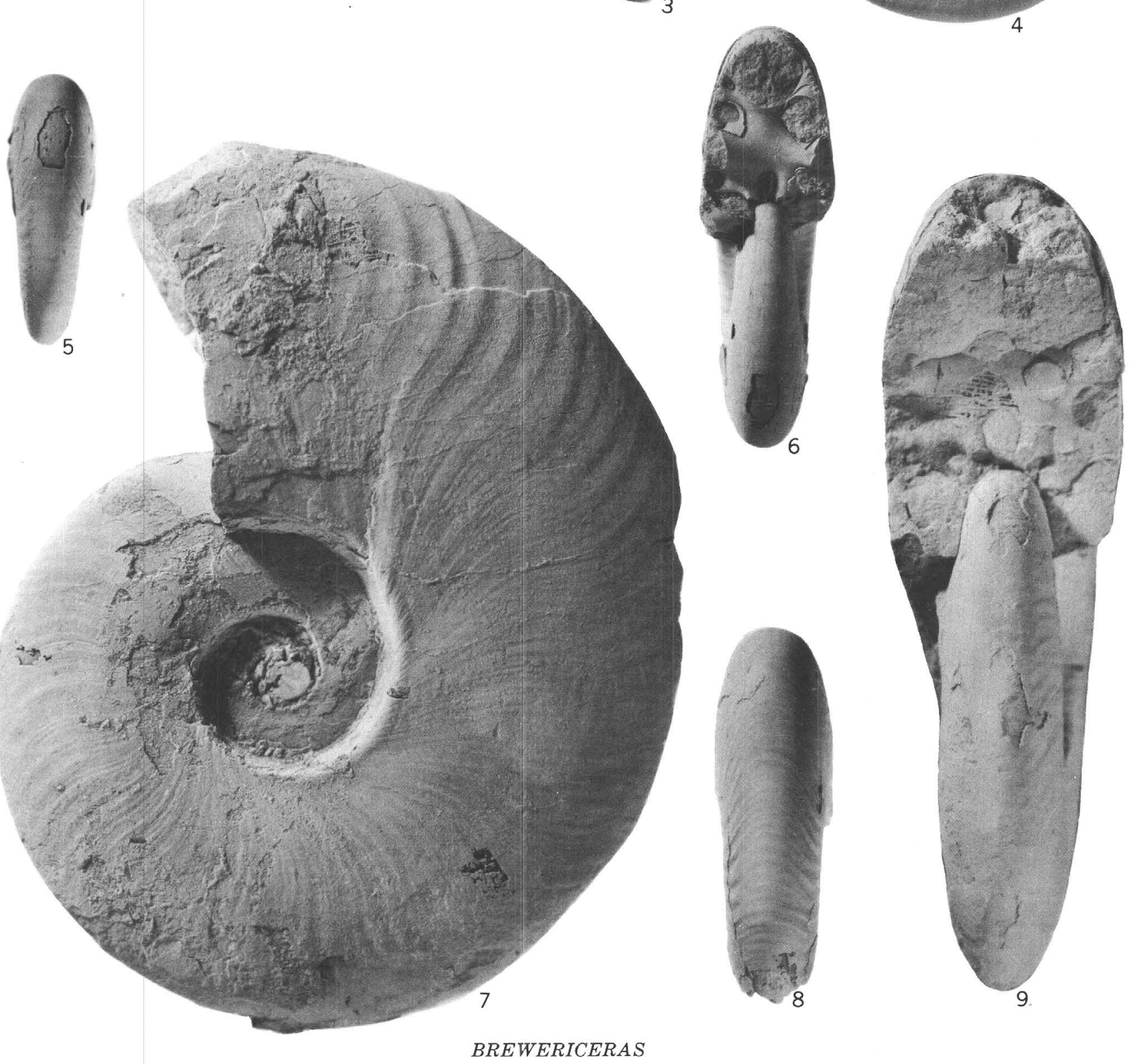




\section{PLATE 10}

[All figures natural size]

Figures 1-15. Brewericeras hulenense (Anderson) (p. F16).

From USGS Mesozoic loc. M1337, Upper Chitina Valley, southern Alaska. Specimens show intergradation from smooth to coarsely ribbed forms.

1- 2. Hypotype, USNM 121529.

3- 5. Hypotype, USNM 121530.

6- 8. Hypotype, USNM 121531.

9-10. Hypotype, USNM 121532.

11-13. Hypotype, USNM 121533.

14-15. Hypotype, USNM 121534. 
GEOLOGICAL SURVEY

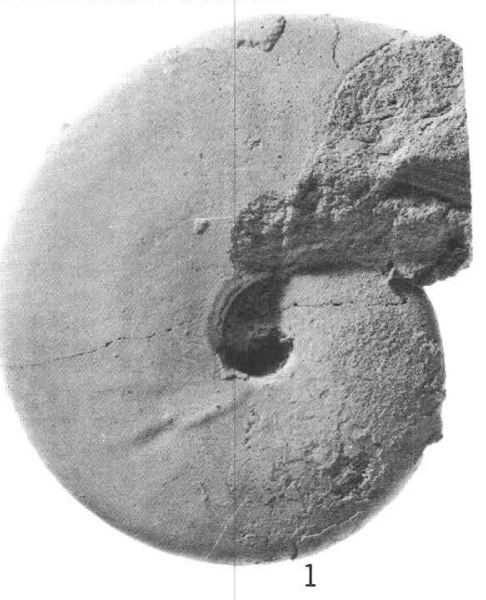

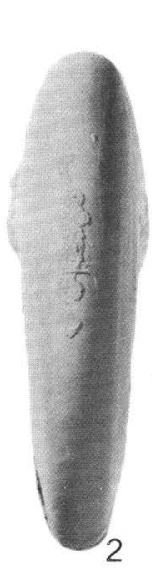

PROFESSIONAL PAPER 503-F PLATE 10
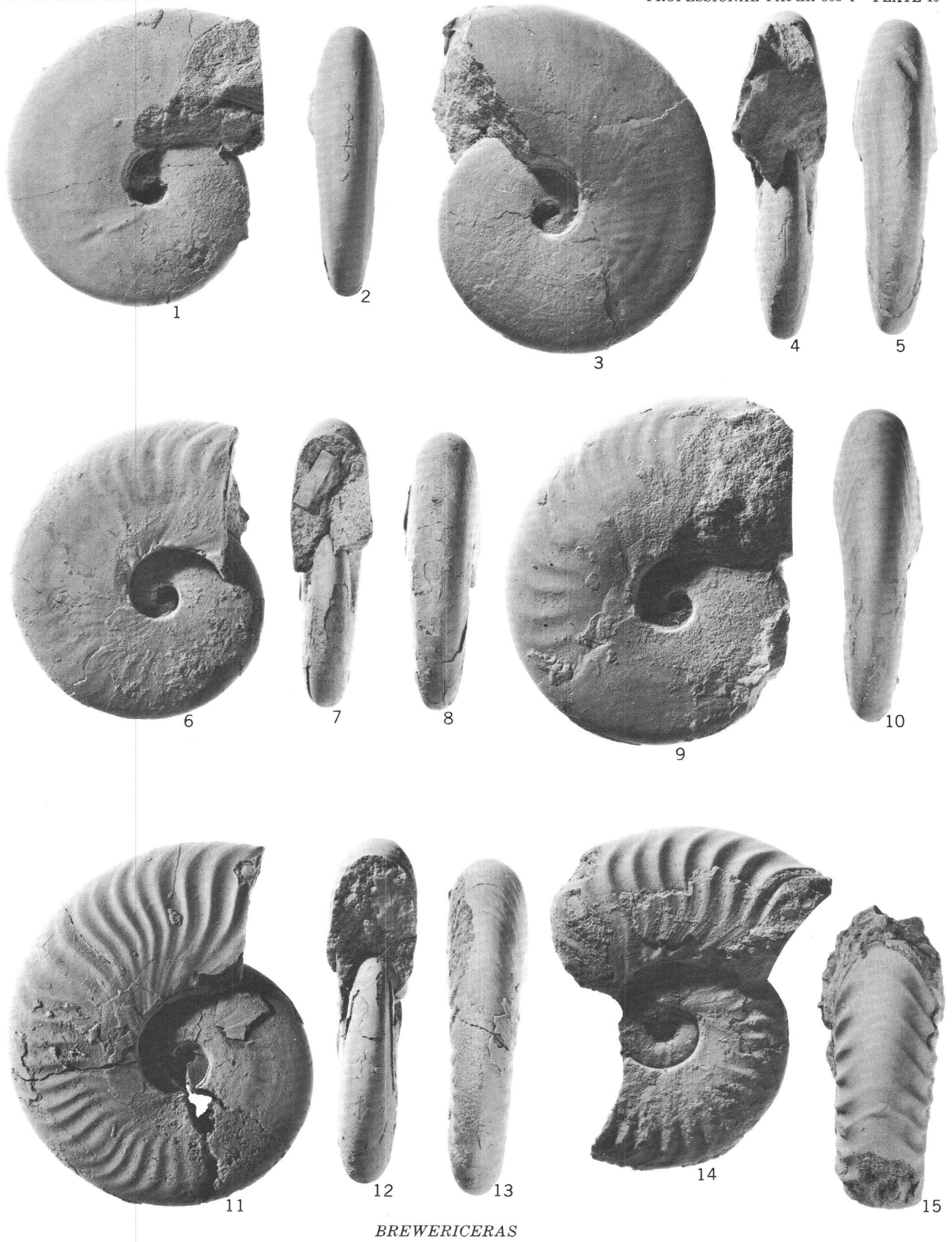


\section{PLATE 11}

[All figures natural size]

Figures 1-3, 13, 14. Brewericeras hulenense (Anderson) (p. F16).

1-3. Hypotype, USNM 121535, from UCR loc. 1000, northern California.

13, 14. Hypotype, USNM 121536, from UCR loc. 1000. This specimen has coarser ribs on lower flank than is usual for this species.

4-6. Leconteites lecontei (Anderson) s. s.

Hypotype, USNM 121537, from UCR loc. 358. Compare bifurcating ribs of this specimen to simple ribs on figs. 1-3.

7-12, 15-17. Forms intermediate between Brewericeras hulenense and Leconteites lecontei.

7-9. USNM 121538, from UCR loc. 70. Specimen has nonbifurcating ribs that are finer than usual for $B$. hulenense and small umbilical nodes similar to those of $L$. lecontei.

10-12. USNM 121539, from UCR 1000. Inner whorls have strong umbilical nodes and bundled ribs of $L$. lecontei; outer whorls have simple ribs of $B$. hulenense.

15-17. USNM 121540, from UCR loc. 402. Coarse ribbed forms with bifurcating ribs on early whorls and simple but unusually strong ribs on outer whorls. 
GEOLOGICAL SURVEY

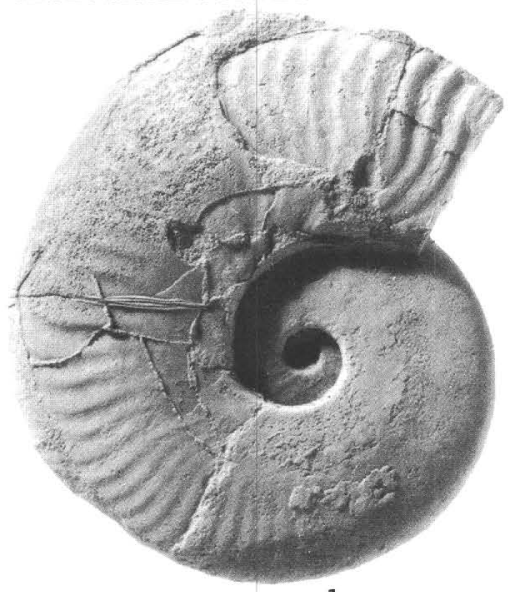

1

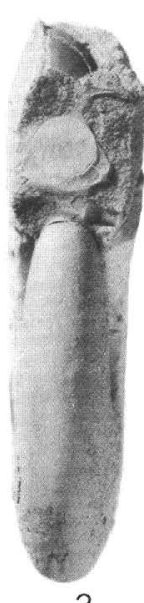

2

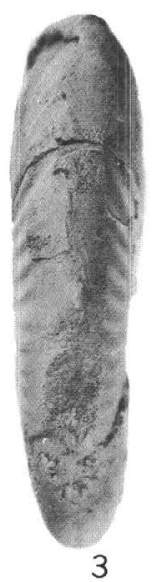

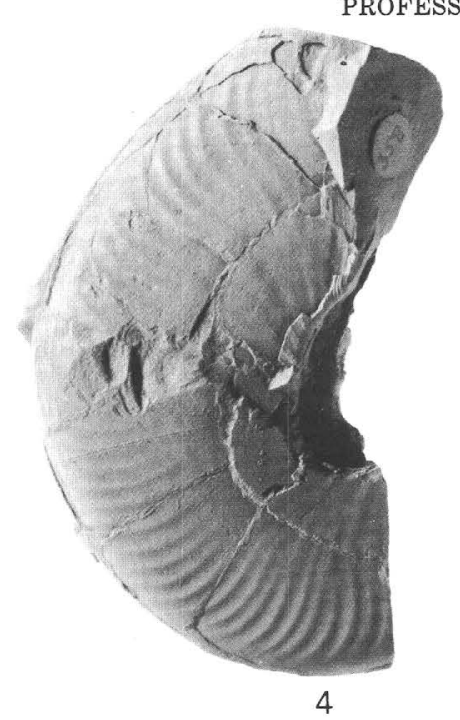

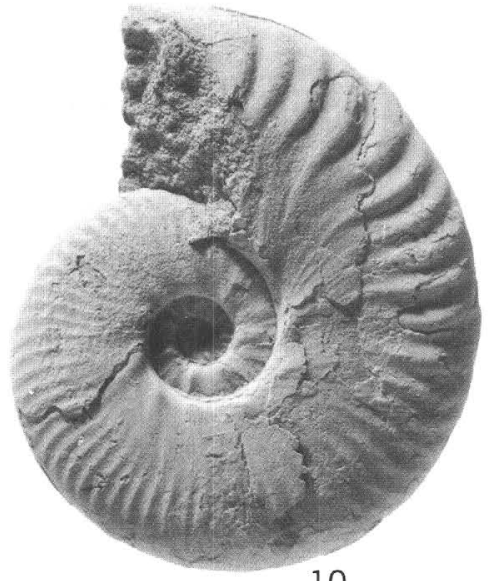

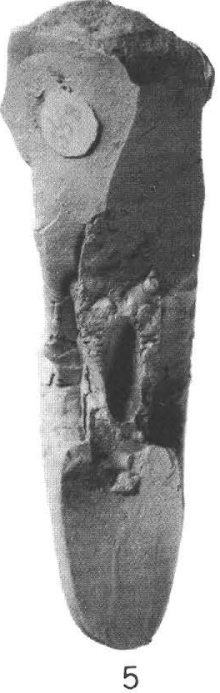
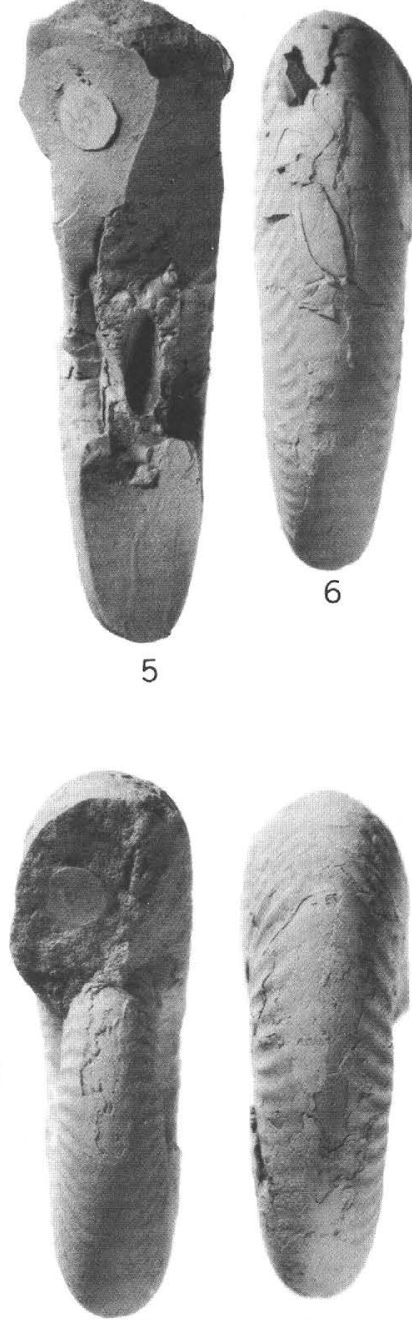

11

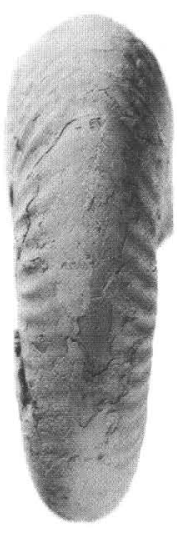

12
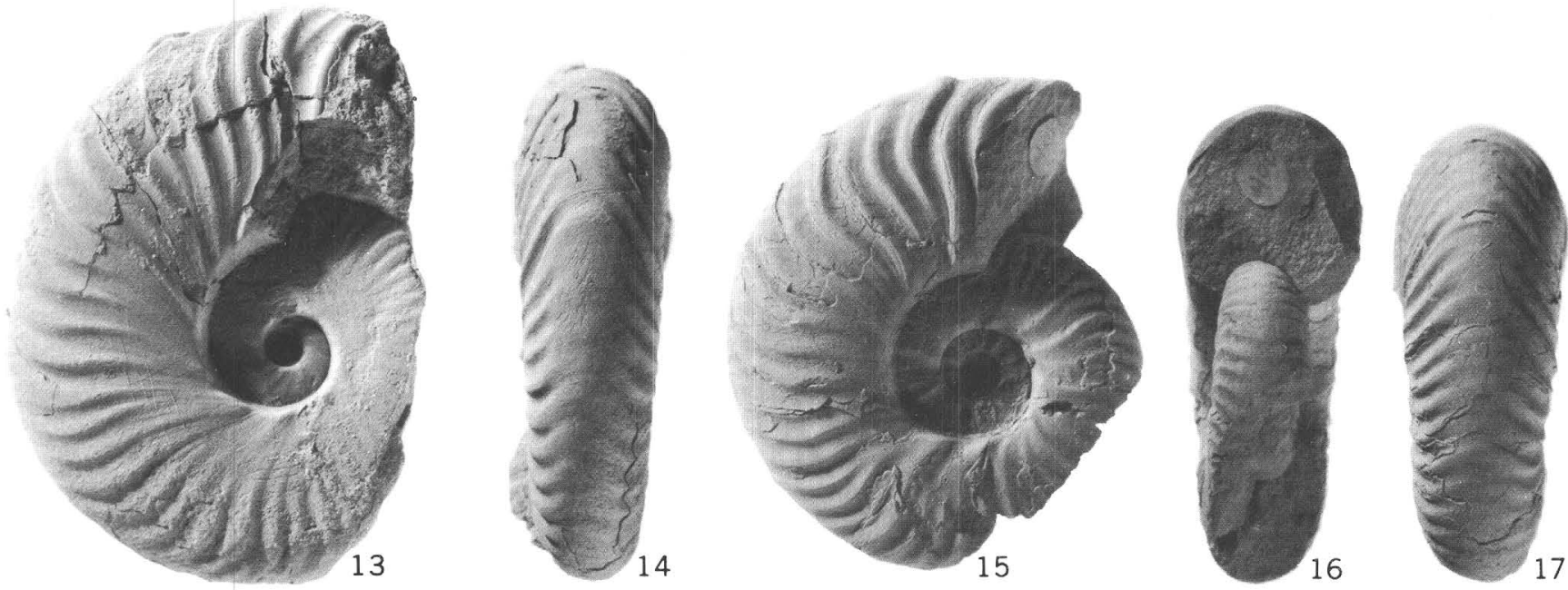

LECONTEITES AND BREWERICERAS 



\section{Contributions to}

\section{Paleontology}

1964

GEOLOGIGAL SURVEY PROFESAIONAL PAPER FO3

This volume was published

as separate chapters $A-F$

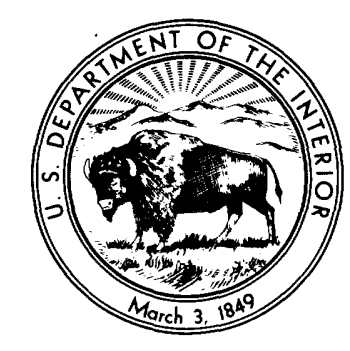




\section{UNITED STATES DEPARTMENT OF THE INTERIOR STEWART L. UDALL, Secretary GEOLOGIGAL SURVEY Thomas B. Nolan, Director}




\section{CONTENTS}

[Letters designate the separately published chapters]

(A) Paleozoic gastropods from the Moose River synclinorium, northern Maine, by Arthur J. Boucot and Ellis L. Yochelson.

(B) Some western American Cenozoic gastropods of the genus Nassarius, by W. O. Addicott.

(C) Early Permian vertebrates from the Cutler Formation of the Placerville area, Colorado, by George Edward Lewis and Peter Paul Vaughn.

(D) Marine Jurassic gastropods, central and southern Utah, by Norman F. Sohl.

(E) Revision of some Paleozoic coral species from the western United States, by William J. Sando.

(F) The Lower Cretaceous (Albian) ammonite genera Leconteites and Brewericeras, by David L. Jones, Michael A. Murphy, and Earl L. Packard. 




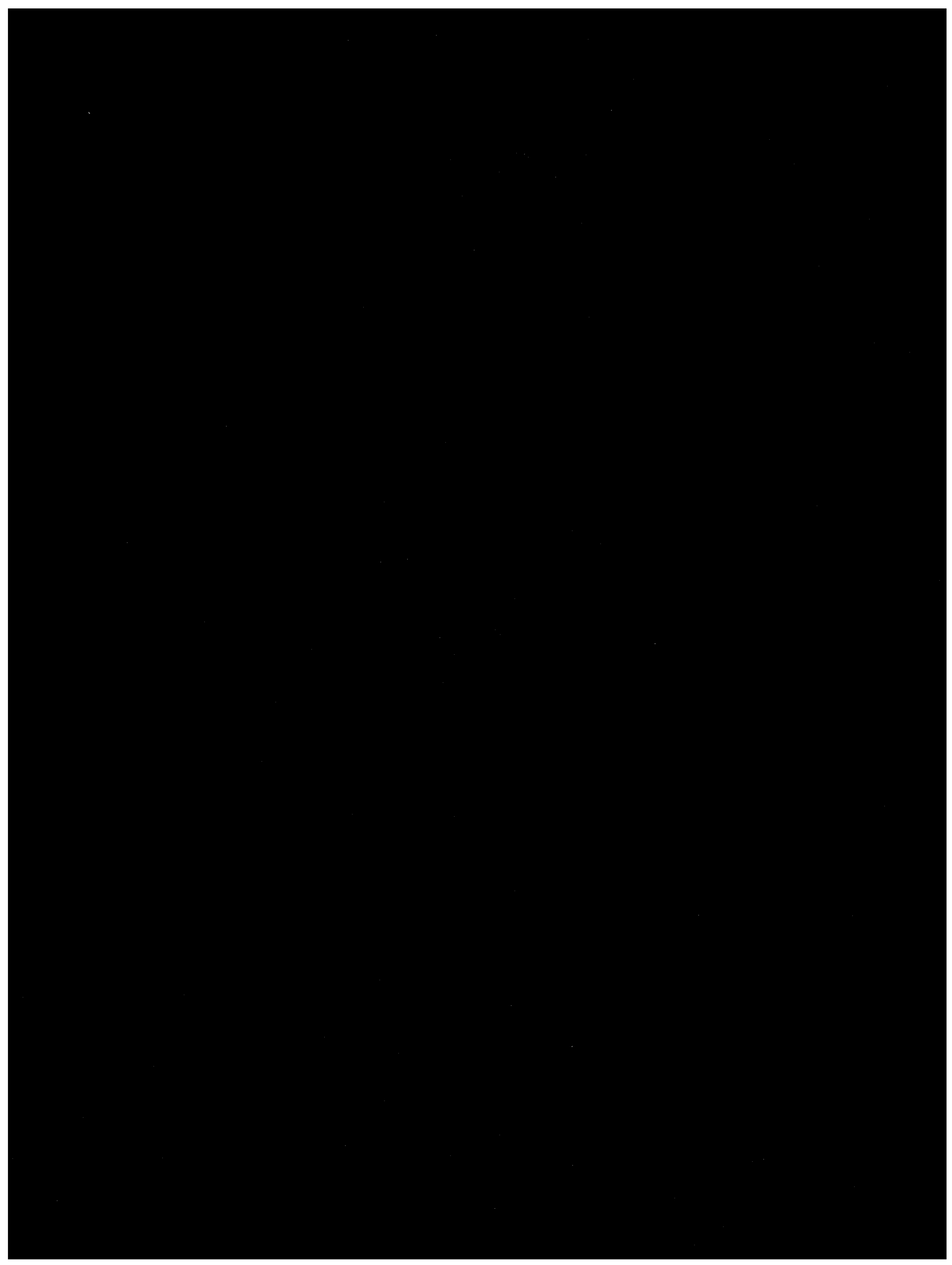




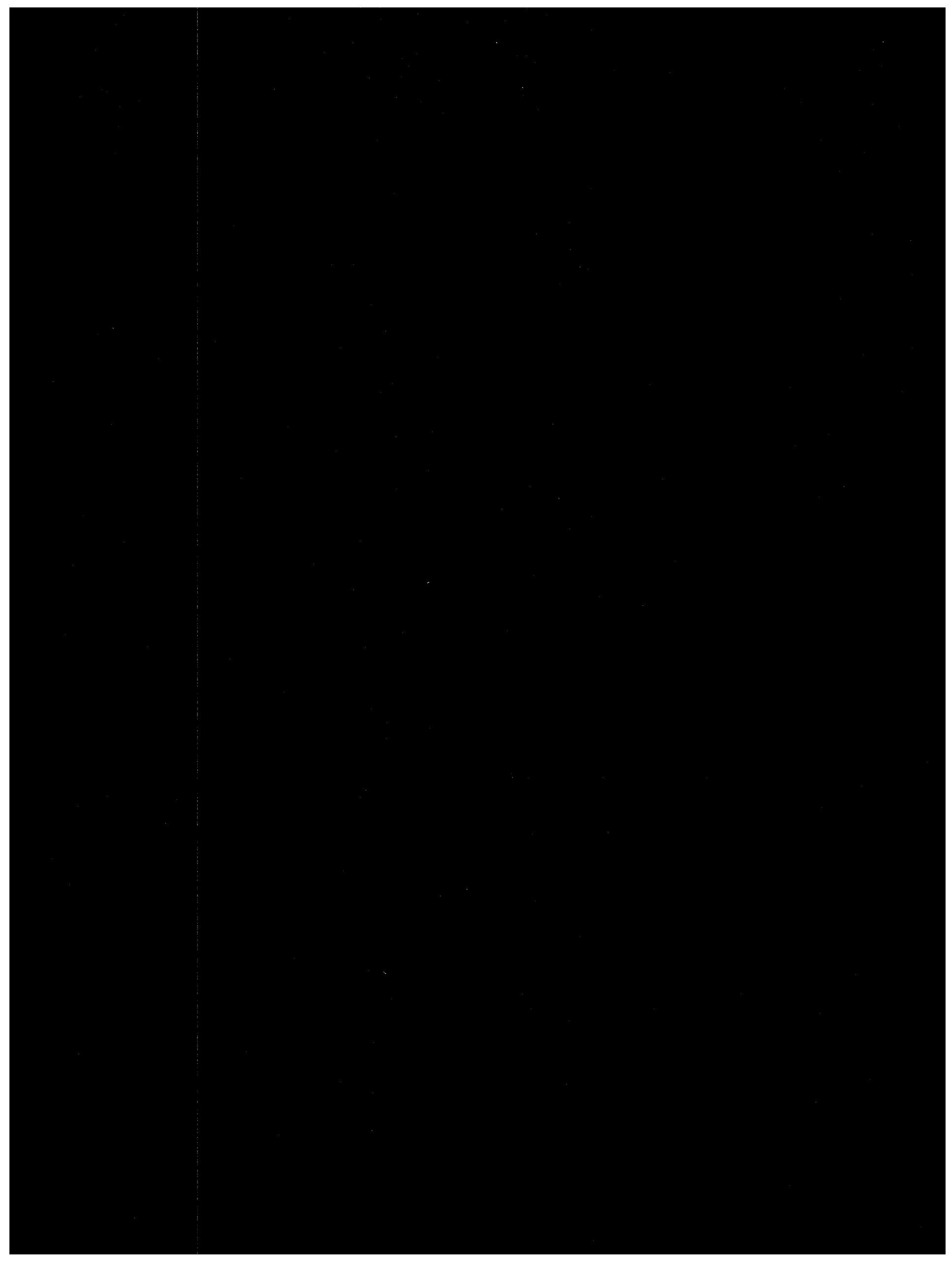

